\title{
Evaluation of Millstone Nuclear Power Plant, Environmental Impact Prediction, Based on Monitoring Programs
}

by

K. L. Gore

J. M. Thomas

L. D. Kannberg

D. G. Watson

February 1977

Prepared for the US. Nuclear

Regulatory Commission 


\section{NOTICE}

This report was prepared as an account of work sponsored by the United States Government. Neither the United States nor the United States Nuclear Regulatory Commission, nor any of their employees, nor any of their contractors, subcontractors, or their employees, makes any warranty, express or implied, or assumes any legal liability or responsibility for the accuracy, completeness or usefulness of any information. apparatus, product or process disclosed, or represents that its use would not infringe privately owned rights.

\section{PACIFIC NORTHWEST LABORATORY \\ operated by \\ BATTEUF \\ for the}

U.S. ENERGY RESEARCH AND DEVELOPMENT ADMINISTRATION

Under Contract $E(45-1)-1830$ 


\title{
Evaluation of Millstone Nuclear Power Plant, Environmental Impact Prediction, Based on Monitoring Programs
}

\author{
by \\ K. L Gore \\ d M. Thomas \\ L D. Kannberg \\ D. G. Watson
}

February 1977

Prepared for the US. Nuclear

Regulatory Commission

Battelle

Pacific Northwest Laboratories

Richland, Washington 99352 


\section{PREFACE}

In order to evaluate environmental programs conducted in conjunction with constructing and operating nuclear power plants, three plants were selected, in which we assisted the Nuclear Regulatory Commission in preparing the Environmental Impact Statements. The three plants selected, Monticello, Haddam Neck, and Millstone, represent those which we believe had the best environmental programs. Or choice was based, in large part, on monitoring programs covering the longest time span. Thus, while the state-of-the-art of power plant monitoring has improved since the 1960s to a point where these environmental programs may not appear to be "up-to-date," they were among the best of their period. We urge the reader to keep this in mind when reviewing this document. 


\section{ACKNOWLEDGMENTS}

We wish to acknowledge the many people who gave of their time and effort and enabled us to produce this report.

Special thanks go to Dr. Robert Hillman of Clapp Laboratories who gathered much of the raw data that was not available on computer. In addition, special thanks are acknowledged to Ms. Theodora Bugsch of Clapp Laboratories and Ms. Claire Mathews of Battelle-Columbus who provided us with the computer coding for the available data.

With the help of several people at Northeast Utilities, especially Dr. William Renfro and Mr. Paul Jacobson, the time necessary for us to assess the data and write this report was shortened.

Our thanks go to Ms Judy Helbling of PNL, who assisted with the editing and publishing of this report. 


\section{CONTENTS}

PREFACE . . . . . . . . . . . . . . . . i ii

ACKNOWLEDGMENTS . . . . . . . . . . . . . . . . $1 \mathrm{~V}$

CONTENTS. . . . . . . . . . . . . . . . . V v

FIGURES . . . . . . . . . . . . . . . . . vii

TABLES . . . . . . . . . . . . . . . $1 \mathbf{x}$

I. INTRODUCTION . . . . . . , . . . . . , . . . 1

i I. PlANT Site AND histORY . . . . . . . . . . . . . . . . 3

III. PLANT DESIGN AND CHARACTERISTICS. . . . . . . . . . . . 7

IV. SUMMARY OF THERMAL MONITORING PROGRAMS. . . . . . . . . . 9

NONECOLOGICAL . . . . . . . . . . . . . . . . 9

ECOLOGICAL . . . . . . . . . . . . . . . . . 9

V. SUMMARY OF ECOLOGICAL MONITORING PROGRAMS . . . . . . . 11

VI. PREDICTED IMPACTS AND TECHNICAL SPECIFICATIONS . . . . . 19

VII. RATIONALE FOR DATA SYNTHESIS . . . . . . . . . . . 21

STUDiES EVALUATED. . . . . . . . . . . . . . . 21

STUDIES NOT EVALUATED . . . . . . . . . . . . . . 22

VIII. ANALYSIS OF THERMAL MONITORING PROGRAMS . . . . . . . . 25

NONECOLOGICAL THERMAL MONITORING. . . . . . . . . . 25

MODELS . . . . . . . . . . . . . . . . . 29

ECOLOGICAL . . . . . . . . . . . . . . . . . 34

Introduction. . . . . . . . . . . . . . . 34

Trawl and Ichthyoplankton . . . . . . . . . 34

Ichthyoplankton - Thermal Plume . . . . . . . . 37

Water Quality . . . . . . . . . . . . . . 38 
SUMMARY . . . . . . . . . . . . . . . . 38

IX. ANALYSIS OF ECOLOGICAL MONITORING PROGRAMS . . . . . . . 41

ROCKY SHORE COMMUNITIES. . . . . . . . . . . . . . 41

Summary . . . . . . . . . . . . . . . . 48

BARNACLE STUDY. . . . . . . . . . . . . . . . 49

Summary . . . . . . . . . . . . . . 52

INTERTIDAL SAND INFAUNA. . . . . . . . . . . . . . 52

Summary . . . . . . . . . . . . . . . . 52

OYSTER GROWTH STUDY . . . . . . . . . . . . . . 54

Summary . . . . . . . . . . . . . . 59

TRACE METALS . . . . . . . . . . . . . 59

Summary . . . . . . . . . . . . . . 65

SHORE-ZONE FISH (BEACH SEINING) . . . . . . . . . . 65

Summary . . . . . . . . . . . . . . . . 70

IMPINGEMENT. . . . . . . . . . . . . . . . . . . . . 71

Summary . . . . . . . . . . . . . . . . 71

EXPOSUREPANEL. . . . . . . . . . . . . . . . . 77

Summary . . . . . . . . . . . . . . . . 78

WINTER FLOUNDER MODEL . . . . . . . . . . . . . 78

Summary . . . . . . . . . . . . . . . . 80

ENTRAINMENT. . • . . . . . . . . . . . . . . 80

Summary . . . . . . . . . . . . . . . . 82

literaturecited . . . . . . . . . . . . . . . . 83

DISTRIBUTION . . . . . . . . . . . . . . . . 85 


\section{FIGURES}

1 Millstone General Site Area to Within $80 \mathrm{~km}$. . . . . . 4

2 Gross Monthly Power Output (1971-1974) at Millstone

Nuclear Power Station

3 Composite of the Ecological Sampling Stations at

Millstone Nuclear Power Station. . . . . . . . . . 17

4 Predicted vs Measured Thermal Patterns (from March 1972

Survey-Unit 1). . . . . . . . . . . . . . . . 30

5 Tidal Circulation Model. . . . . . . . . . . . 32

6 Comparison of Field and Tidal Model Current Data . . . . 33

7 Ichthyoplankton Sampling Stations . . . . . . . . . 35

8 Ichthyoplankton, Temperature $\left({ }^{\circ} \mathrm{C}\right)$ at Stations 5,6 and 8...'. . . . . . . . . . . . . . . . 36

9 Temperatures $\left({ }^{\circ} \mathrm{C}\right)$ at Ichthyoplankton Station $10 . \quad . \quad . \quad 37$

10 Difference Between Adult Barnacle Diameters (mm) at 50

11 Difference Between Adult Barnacle Diameters (mm) at

12 Difference Between Adult Barnacle Diameters (mm) at

Giants Neck and White Point . . . . . . . . . . . 51

13 Difference Between Number of Total Intertidal Sand

Organisms (Number $/ \mathrm{cm}^{3}$ ) at Giants Neck and Jordan Cove. . . 53

14 Differences Between Numbers of Gemma gemma (Organisms/3197

$\mathrm{cm}^{3}$ ) a t Giants Neck and Jordan Cove. . . . . . . . 54

15 Difference Between Average Weight (g) for Adult Oysters at Giants Neck and Other Stations . . . . . . . . . 56

16 Difference Between Average Length $(\mathrm{mm})$ for Adult Oysters at Giants Neck and Other Stations . . . . . . . . 56

17 Relationship Between Average Weight (g) and Length (mm) for Adult Oysters at the Millstone Point Area (1970-1974). 
Levels of Copper (ppm) in Oysters, Mussels and Seawater at Several Stations at Millstone Nuclear Power

Station . . . . . . . . . . . . . . . .

19 Levels of Zinc (ppm) in Oysters, Mussels and Seawater at Several Stations at Millstone Nuclear Power Station. . . . . . . . . . . . . . . .

20 Levels of Iron (ppm) in Oysters, Mussels and Seawater at Several Stations at Millstone Nuclear Power Station . . . . . . . . . . . . . . . . .

21 Differences (ppm) Between Copper, Zinc and Iron Levels in Oysters at Giants Neck or Fox Island and Quarry Cut Stations . . . . . . . . . . . . . .

22 Total Numbers of Menidia menidia Caught Using Bag Seine Collections at Four Stations During 1969-1974 in the Millstone Point Area . . . . . . . . . . . 66

23 Total Number of Fundulus majalis Caught Using Bag Seine Collections at Four Stations During 1969-1974 in the Millstone Point Area . . . . . . . . . . . . 67

24 Total Fish Caught in Three Seine Hauls at Giants Neck and Jordan Cove (1969-1974) . . . . . . . . . . . 68

25 Monthly Estimates of Average Economically Important Fish and Total Organisms Impinged/Day at the Millstone Nuclear Power Station . . . . . . . . . .

26 Percentage Distribution of Impingement by Size Categories for the Most Numerous Species Impinged at Millstone Nuclear Power Station in 1972. . . . . . . . .

27 Percentage Distribution of Impingement by Size Categories for the Most Numerous Species Impinged a t Millstone Nuclear Power Station in 1973. . . . . . . . . .

28 Percentage Distribution of Impingement by Size Categories for the Most Numerous Species Impinged a Millstone Nuclear Power Station in 1974. 


\section{TABLES}

1 Summary of Terminated Ecological Monitoring Program at Millstone Nuclear Power Station. . . . . . . . . . 12

2 Summary of Continuing Ecological Monitoring Programs a Millstone Nuclear Power Station. . . . . . . . . 13

3 Summary of Special Ecological Studies (Entrainment, Impingement, etc.) at Millstone Nuclear Power Station . . . . 15

4 Summary of Nonecological Hydrology Monitoring Programs . . . . 26

5 Estimated Coverage (\%of Total 'Transect Area Covered) for Selected Flora and Fauna in the Millstone Point Area . . . 42

6 Differences Between Coverage (\% of Total Transect Area Covered) for the Algal Ascophyllum nodosum at Control and Heated Stations. . . . . . . . . . . . . . 44

7 Differences Between Coverage (\% of Total Transect Area Covered) for the Barnacle Balanus balanoides at Control and Heated Stations. . . . . . . . . . . . . . .

8 Differences Between Coverage (\% of Total Transect Area Covered) for algae Fucus spp at Control and Heated Stations . . 46

9 Differences Between Coverage (\%of Total Transect Area Covered) for the algal Chondrus crispus at Control and Heated Stations. . . . . . . . . . . . . .

10 Average Base Diameters (mm) for Adult Barnacles taken at the Millstone Point Area . . . . . . . . . . . .

11 Total Number of Intertidal Sand Organisms and Number of Gemma gemma (Organisms $/ 3197 \mathrm{~cm}^{3}$ ) taken a the Millstone Point Area. . . . . . . . . . . . . . . . . .

12 Average Weight (g) and Length (mm) for Adult Oysters Held in Trays a t the Millstone Point Area . . . . . . . . . . 55

13 Statistics for "Growing Season" Weights and Lengths of Oysters at the Millstone Point Area . . . . . . . . . .

14 Linear Regressions for Average Adult Oyster Weight on Oyster Length at Four Millstone Point Area Stations . . . .

15 Metal Concentrations (ppm) for Tray Grown Oysters Tissue at Millstone Nuclear Power Station. . . . . . . . . . . 
16 Totals for the Most Numerous Species Caught in Seine Hauls at the Millstone Point Area . . . . . . . . . . . . .

17 Physical Characteristics of Beach Seine Stations at Millstone Point Area . . . . . . . . . . . . . . .

18 Arithmetic Means of Preoperational and Operational Beach Seine Station Ratios for Three Selected Species and all Fish at Millstone Point Area. . . . . . . . . . . .

19 Yearly and Summer Means [Total of three $(30 \mathrm{~m})$ Seine Hauls] for Total Fish Caught at the Millstone Point Area . . . . . . . 70

20 Total Impingement/Month and Average Impingement/Day for the Most Numerous Economically Important Fish Species for 1972 at Millstone Nuclear Power Station. . . . . . . . . .

Total Impingement/Month and Average Impingement/Day for the Most Numerous Economically Important Fish Species for 1973 at Millstone Nuclear Power Station. . . . . . . . . . . 72

Total Impingement/Month and Average Impingement/Day for the Most Numerous Economically Important Fish Species for 1974 at Millstone Nuclear Power Station . . . . . . . .

23 Numbers of the Most Numerous Species Impinged by Size Categories for Mil lstone Unit 1, in 1972 (275 Days Monitored) . . 74

24 Numbers of the Most Numerous Species Impinged by Size Categories for Mi 11stone Unit 1, in 1973 (361 Days Monitored) . . 74

25 Numbers of the Most Numerous Species Impinged by Size Categories for Millstone Unit 1, in 1974 (361 Days Monitored). 
I. INTRODUCTION 
EVALUATION OF MILLSTONE NUCLEAR POWER PLANT, ENVIRONMENTAL IMPACT PREDICTION, BASED ON MONITORING PROGRAMS

\section{INTRODUCTION}

This is the third report of a series that quantitatively evaluates the nonradiological monitoring programs at three nuclear power plants. The results from our evaluation of Monticello and Haddam Neck Nuclear Power Plants were previously reported (Gore et. al., 1976a and 1976b). This report represents our analysis of Millstone Nuclear Power Plant.

The objectives of this study are: 1) to evaluate quantitatively the hydrological and ecological monitoring programs as to their effectiveness in determining if predicted Environmental Statement (ES) or unexpected impacts occurred due to power plant operations; 2) to determine if the Environmental Technical Specifications (Tech Specs) adequately address the potential impacts predicted in the FES or any other potential impact the Tech Specs require; and 3) to determine if the sampling design of the monitoring program was sufficiently sensitive to differentiate between natural variation and power plant-induced effects.

To accomplish these goals, both operational as well as preoperational monitoring programs were analyzed to produce long-term (5 yr or longer) data sets, where possible. In order to determine the effectiveness of these monitoring programs, the appropriate data sets have to be analyzed by the appropriate statistical analysis. Thus, both open literature and current statistical analysis being developed at Pacific Northwest Laboratories (PNL) were employed in data analysis.

A final Summary Report is being prepared which summarizes the results from the first three reports (Monticel 10, Haddam Neck and Millstone), presents our conclusions as to their effectiveness in measuring environmental impacts, and presents our recommendations for possible improvement of nuclear power plant monitoring (hydrological and ecological). 
II. PLANT SITE AND HISTORY 


\section{PLANT SITE AND HISTORY}

Millstone Nuclear Power Plant is located in Waterford, Connecticut, on Millstone Point, a peninsula jetting southward into Long Island Sound. Niantic Bay is located west of the plant site. Nkw London is about $5.2 \mathrm{~km}$ to the east with Hartford about $64 \mathrm{~km}$ northwest and Brookhaven $29 \mathrm{~km}$ southwest (Figure 1). The plant occupies about 200 hectares of land. Metropolitan areas of Connecticut, Rhode Island and New York are within $80 \mathrm{~km}$. The surrounding area consists of residential areas, institutional and governmental property, state parks and agricultural areas.

The mean tidal range of the Connecticut River at the plant site is about $0.8 \mathrm{~m}$ with a corresponding flow of $3468 \mathrm{~m}^{3} / \mathrm{sec}$. Salinities vary seasonally and range from 26 to 32 ppt. The salt water intrusion comes from the Atlantic Ocean via Block Island Sound and most of the fresh water enters from Niantic River and Bay. Diatoms are the principal phytoplankton group. Zooplankton are typical of Atlantic Coast estuaries with Acartia spp. and ctenophores the seasonally abundant forms. Benthic communitites are composed of barnacles, snails and mussels. The American lobster is of commercial and sport importance with scallops, clams and crabs also supporting local fisheries. Striped bass, bluefish, winter flounder, weakfish, sculp, and sea bass are important sport fish. The commercially important Atlantic menhaden is common to the plant area in late summer and fall.

On 10 November 1965, application was made to the former Atomic Energy Commission (now Nuclear Regulatory Commission) for al1 necessary permits and licenses to construct and operate a single unit nuclear generating facility by the Millstone Point Company. A construction permit was issued on 19 May 1966. In March 1970, a notice of intent to issue a provisional operating license for Unit 1 was announced by the AEC. This permit was actually issued on 7 October 1970. However, on 10 June 1970, the applicant submitted an environmental report for the construction of Unit 2. By 22 November 1971, the applicant was still operating under a provisional permit and not until 1 August 1975 did Unit 1 receive its full operating license. Since December 1970, the plant has been averaging about $70 \%$ of full power loads except for refuel ing shutdowns (Figure 2). 


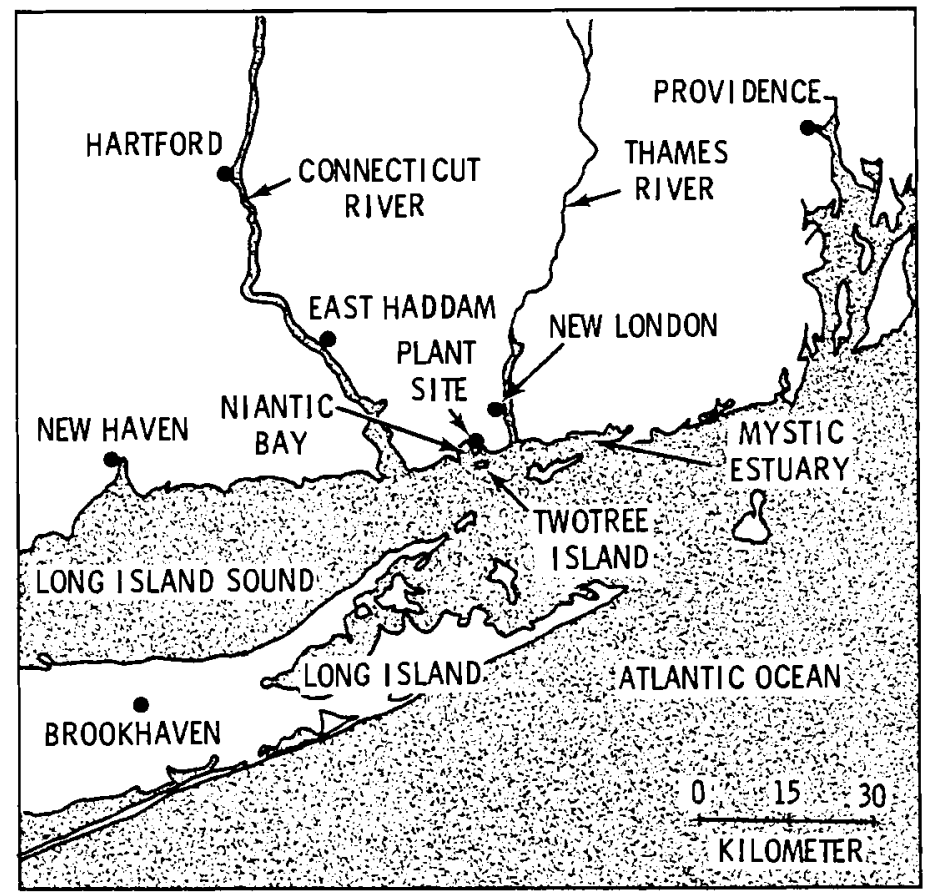

FIGURE 1. Millstone General Site Area to Within $80 \mathrm{~km}$

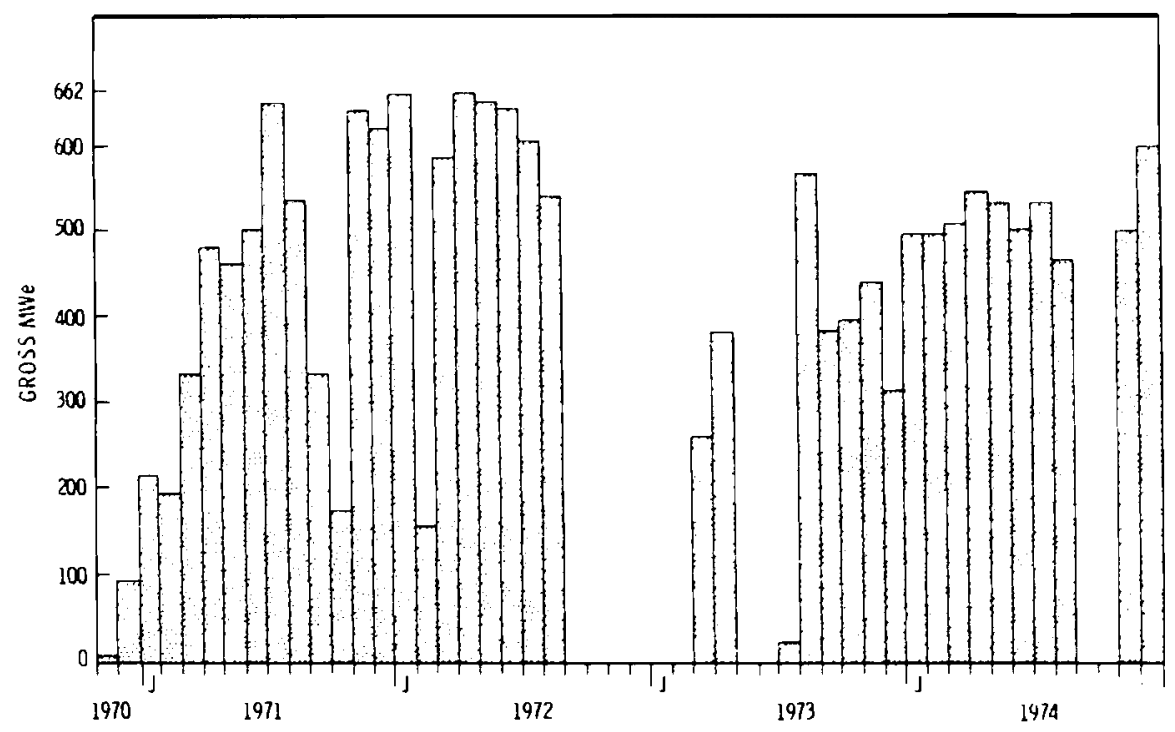

FIGURE 2. Gross Monthly Power Output (1971-1974) at Millstone Nuclear Power Station 
III. PLANT DESIGN AND CHARACTERISTICS 


\section{I . PLANT DESIGN AND CHARACTERISTICS}

Millstone Unit 1 is a single-cycle, forced circulation, boiling water reactor operated by the Millstone Point Company, a subsidiary of Northeast Utilities. The reactor is capable of producing $2011 \mathrm{MW}_{t}$ and $652 \mathrm{MW}_{\mathrm{e}}$ power. The plant withdraws about $27 \mathrm{~m}^{3} / \mathrm{sec}(935 \mathrm{cfs})$ of water from Niantic Bay and discharges about the same volume of water into Long Island Sound via a quarry. The intake structure is shielded by a curtain wall to prevent wam surface water and their organisms from entering the intake. Bar screens and vertical traveling screens $(9.5 \mathrm{~mm}$ mesh) prevent debris and larger organisms from entering the cool ing system. Approach velocities to the traveling screens vary between 15 to $28 \mathrm{~cm} / \mathrm{sec}$ depending on tidal stage. Designed cooling water temperatures rise (AT) across the condensers is $12.8^{\circ} \mathrm{C}$. After water passes through the condensers, it is discharged into Millstone quarry (volume $=1.0 \times 10^{6} \mathrm{~m}^{3}$ ). From the quarry, the water travels into a $18 \mathrm{~m}$ by $76 \mathrm{~m}$ discharge canal before entering Long Island Sound by Twotree Island Channel. The discharge velocity varies between $0.14-0.18 \mathrm{~m} / \mathrm{sec}$ depending on tidal stage. A barrier has been installed in the discharge canal to prevent fish from entering the quarry. 
IV. SUMMARY OF THERMAL MONITORING PROGRAMS 


\section{SLMMRY OF THERMAL MONITORING PROGRAMS}

NONECOLOG ICAL

This discussion of methods and program design is incorporated into the Results section on Nonecological Thermal Monitoring.

\section{BCOLOGICAL}

Most of the ecological sampling programs at Millstone measured salinity, dissolved oxygen and temperature data along with the biological collection of organisms (see Tables 1-3). These programs during the course of the study period either terminated, changed direction or remained the same with the majority following the former two criteria. Thus, no program produced comparable preoperational and operational data sets and few actual temperatures were reported in the reports we were able to obtain for analyses.

Few of the ecological programs did report on temperatures taken with the collection of organisms. These programs are discussed in more detail in the results section of this report. 
V. SUMMARY OF ECOLOGICAL MONITORING PROGRAMS 


\section{v. SLMMRY OF BCOLOGICAL MONITORING ROORAMS}

Millstone's ecological monitoring programs consist of about 2-1/2 yr of preoperational data and 4-1/2 yr of operational data. Approximately twenty individual studies have been conducted on different species, communitites, populations and/or physical-chemical parameters in association with the ecological programs. We were able to obtain data through 1974, thus our analyses are limited for the data between 1968-1974.

Monitoring of the aquatic environment began in 1968 and, for the most part, is still continuing. Between 1970 and 1973, six ecological studies out of more than twenty were terminated. These programs (Table 1) had collected data for 2 to $5 \mathrm{yr}$ and were terminated for one of the following reasons: 1) produced only qualitative data, 2) lacked consistency in the results they produced, and 3) results were difficult to interpret due to the qualitative nature of the program. However, most of these studies were replaced by improved, quantifiable monitoring programs.

There are approximately fifteen marine ecology programs presently being conducted at Millstone. Table 2 summarizes these studies in terms of sampling locations, frequency, dates, methods and analyses performed. These include studies on boring and fouling organisms, benthic macroinvertebrates and fish studies. Some of these studies have been in existence on a longterm basis. For example, the boring and foul ing organisms program began in June 1968 and continued beyond 1974. Other studies, such as the lobster population study, have only been in existence since July 1973.

Table 3 summarizes the entrainment, impingement and other related studies in the same manner as the previous two tables. The entrainment program investigated phytoplankton, zooplankton, ichthyoplankton and lobster larvae effects. Some of the individual studies were short, but intense, while others were long-term. For example, special studies were conducted to determine the effect of chlorine on phytoplankton productivity (6 month duration) whereas study of the effect of ichthyoplankton passage has been 
TABLE 1. Summary of Terminated Ecological Monitoring Program at Millstone Nuclear Power Station

\begin{tabular}{|c|c|c|c|c|c|c|}
\hline PROGRAM & $\begin{array}{l}\text { COLLECTION } \\
\text { DATES }\end{array}$ & $\begin{array}{l}\text { COLLECTION } \\
\text { METHOD }\end{array}$ & $\begin{array}{l}\text { SAMPLING } \\
\text { FREQUENCY }\end{array}$ & $\begin{array}{c}\text { STATION LOCATION } \\
\text { AND NUMBER }\end{array}$ & $\begin{array}{l}\text { ANALYSIS } \\
\text { PERFORMED }\end{array}$ & REMARKS \\
\hline PLANKTON & MAY 199 - SEP 1972 & $\begin{array}{l}\text { ZOOPLANKTON } \\
\text { CLARK-BUMPUS } \\
\text { (NO. } 20 \text { AND NO. } 6 \\
\text { MESH NETS) } \\
\text { PHYTOPLANKTON } \\
\text { SURRACE AND } 15 \mathrm{~m} \\
\text { DEPTH WITH VAN } \\
\text { DORN BOTTLE }\end{array}$ & EEB, MAY, AUG, NOV & $\begin{array}{l}\text { ONE STATION-IN LONG } \\
\text { ISLAND SOUND JUST } \\
\text { OUTSIDE OF QUARRY. } \\
3 \text { HOUR OR } 4.8 \mathrm{~km} \\
\text { CLARK-BUMPUS TOW. } \\
\text { VAN DORN BOTILE } \\
\text { COLLECTION AT APPROX- } \\
\text { IMATE SAME LOCATION }\end{array}$ & $\begin{array}{l}\text { PACK-CELL VOLUME } \\
\text { DETERMINATION (MAY } \\
1969 \text { - MAY 1970) JUN } \\
1970 \text { - SEP 1972. (SPECIES } \\
\text { ENUMERATION). } \\
\text { CHLOROPHYLL A FOR VAN } \\
\text { DORN SAMPLE. SALINITY } \\
\text { AND D. O. WITHEACH TOW }\end{array}$ & $\begin{array}{l}\text { TERMINATED BECAUSE IN- } \\
\text { ADEQUATE TO COMPLEMENT } \\
\text { ENTRAINMENT STUDIES }\end{array}$ \\
\hline LOBSTER SURVEY & JUL $\mathbf{1 \% 8 ~ - ~ M A R ~} 1973$ & $\begin{array}{l}\text { VISUAL } \\
\text { OBSERVATION BY } \\
\text { SCUBA DIVERS FOR } \\
\text { ONE 6lm TRANSECT }\end{array}$ & $\begin{array}{l}\text { MAY, JUL, SEP AND } \\
\text { ONCE DURING WINTER }\end{array}$ & $\begin{array}{l}\text { TWO STATIONS, ONE } \\
\text { JUST OFF QUARRY AT } \\
\text { 9.1m DEPTH AND SECOND } \\
\text { OFF SEASIDE POINT } \\
\text { (ESTABLISHED I N JUL } \\
\text { 1970) }\end{array}$ & $\begin{array}{l}\text { COUNTS OF ALL PLANTS } \\
\text { AND ANIMALS, } \\
\text { ESPECIALLY LOBSTERS } \\
\text { AND SOME FISH }\end{array}$ & $\begin{array}{l}\text { REPLACED BY A MORE } \\
\text { QUANTITATIVE BENTHIC AND } \\
\text { LOBSTER TAGGING PROGRAM }\end{array}$ \\
\hline $\begin{array}{l}\text { LOBSTER POT } \\
\text { SURVEY }\end{array}$ & FEB 1\%9 - MAY 1973 & $\begin{array}{l}\text { COMMERCIAL CATCH } \\
\text { RECORDS AND OWN } \\
\text { POT DATA }\end{array}$ & $\begin{array}{l}\text { FEB, MAY, JUL. SEP. } \\
\text { POTS SET FOR } 1 \\
\text { WEEK DURING EACH } \\
\text { QUARTER }\end{array}$ & $\begin{array}{l}\text { TWO STATIONS - FOX } \\
\text { ISLAND AND SEASIDE } \\
\text { POINT. } 6 \text { POTS I } \\
\text { STATION }\end{array}$ & $\begin{array}{l}\text { TOTAL NUMBER AND } \\
\text { TOTAL LENGTH }\end{array}$ & $\begin{array}{l}\text { PROGRAM REPLACED BY } \\
\text { A MORE INTENSIVE LOBSTER } \\
\text { TAGGING STUDY }\end{array}$ \\
\hline OYSTER SEED GROWTH & AUG 1\%8 - FEB 1970 & OYSTER TRAY & $\begin{array}{l}\text { MAY. JUL, SEP AND } \\
\text { ONCE WRING WINTER }\end{array}$ & $\begin{array}{l}\text { FOUR STATIONS - } \\
\text { WHITE POINT, FOX } \\
\text { ISLAND, BLACK POINT } \\
\text { (MOVED TO GIANTS } \\
\text { NECK IN MAY } 1969 \text { ) } \\
\text { AND JUST OUTSIDE OF } \\
\text { QUARRY (MOVED TO } \\
\text { INSI DE QUARRY IN } \\
\text { DEC 1\%99) }\end{array}$ & $\begin{array}{l}\text { MAXIMUM LENGTH AND } \\
\text { CONDITION INDEX (DRY } \\
\text { WEIGHT MEAT DIVIDED } \\
\text { BY WEIGHT WET) }\end{array}$ & $\begin{array}{l}\text { TERMINATED DUE TO TOO } \\
\text { MANY UNCONTROLLABLE } \\
\text { VARIABLES }\end{array}$ \\
\hline BARNACLES & MAY 1969 - FEB 1973 & $\begin{array}{l}\text { 30m TRANSECTS WITH } \\
50 \times 50 \mathrm{~cm} \text { QUADRANTS } \\
\text { ALONG ROCKY SHORE- } \\
\text { LINE AT } 1 \mathrm{~m} \text { ABOVE } \\
\text { MEAN LOW WATER }\end{array}$ & $\begin{array}{l}\text { FEB, MAY. JUL, SEP } \\
\text { AND DEC }\end{array}$ & $\begin{array}{l}\text { FIVE STATIONS - } \\
\text { WHITE POINT, FOX } \\
\text { ISLAND (SOUTH AND } \\
\text { NORTH) BAY POINT, } \\
\text { AND GIANTS NECK } \\
\text { (CONIROL) }\end{array}$ & $\begin{array}{l}\text { BASE DIAMETER } \\
\text { MEASUREMENT OF } \mathbf{1} \\
\text { ADULT AND } 1 \mathrm{JUVENILE} \\
\text { WITHIN EACH } 5 \times 5 \mathrm{~cm} \\
\text { GRID }\end{array}$ & $\begin{array}{l}\text { TERMINATED DUE TO LACK } \\
\text { OF CONSI SIENT DATA AND } \\
\text { REPLACED BY A MORE } \\
\text { QUANTITATIVE INTERTIDAL } \\
\text { STUDY }\end{array}$ \\
\hline $\begin{array}{l}\text { INTERTIDAL SAND } \\
\text { INFAUNA }\end{array}$ & MAY $1969-$ MAY 1973 & $\begin{array}{l}\text { CORES } \\
12.7 \mathrm{~cm} \text { DIAMETER } x \\
5 \mathrm{~cm} \text { DEEP FOR } \\
\text { MACROFAUNA. } \quad 3.5 \mathrm{~cm} \\
\text { DIAMETER } \times \mathbf{~} \mathrm{cm} \text { DEEP } \\
\text { FOR NEIOFAUNA }\end{array}$ & $\begin{array}{l}\text { FEB, MAY. JUL, SEP } \\
\text { AND DEC }\end{array}$ & $\begin{array}{l}\text { TWO STATIONS - } \\
\text { JORDAN COVE AND } \\
\text { EASTERN SHORE OF } \\
\text { GIANTS NECK } \\
\text { (CONTROL) }\end{array}$ & $\begin{array}{l}\text { ENUMERATION, } \\
\text { IDENTIFICATION AND } \\
\text { SOME BIOMASS } \\
\text { ESTIMATES. SAND } \\
\text { GRAIN SIZE } \\
\text { DISTRIBUTION }\end{array}$ & $\begin{array}{l}\text { REPLACED BY A MORE } \\
\text { EXTENSIVE AND } \\
\text { QUANTITATIVE BENTHIC } \\
\text { PROGRAM }\end{array}$ \\
\hline
\end{tabular}


TABLE 2. Summary of Continuing Ecological Monitoring Programs at Millstone Nuclear Power Station

\begin{tabular}{|c|c|c|c|c|c|c|}
\hline Program & $\begin{array}{l}\text { Collection } \\
\text { Dates }\end{array}$ & $\begin{array}{l}\text { Collection } \\
\text { Method }\end{array}$ & $\begin{array}{l}\text { Sampling } \\
\text { Frequency }\end{array}$ & $\begin{array}{l}\text { Station Location } \\
\text { and Number }\end{array}$ & Analyses Performed & Remarks \\
\hline $\begin{array}{l}\text { Boring and fouling } \\
\text { organisms }\end{array}$ & June 1968-Dec 1974 & $\begin{array}{l}\text { Rack of } 13 \text { exposure } \\
\text { panels made of White } \\
\text { Pin with transite } \\
\text { backing }\end{array}$ & $\begin{array}{l}\text { Monthly; each month } \\
2 \text { panels removed, } \\
\mathbf{1} \text { exposed for } 1 \text { month, } \\
\text { the other for } 12 \\
\text { months }\end{array}$ & $\begin{array}{l}\text { Six stations-White } \\
\text { Point; Fox Island; } \\
\text { Millstone Haroor; } \\
\text { Black Point (Oct-- } \\
\text { Dec 1968), moved to } \\
\text { Giants Neck. (Jan } \\
\text { 1969): Unit \#1 Intake } \\
\text { (Apr 1969); and Quarry } \\
\text { (jul 1973) }\end{array}$ & $\begin{array}{l}\text { Enumeration, identification, } \\
\text { Chi-Square contingency test } \\
\text { and diversity index }\end{array}$ & $\begin{array}{l}\text { Station at Giants } \\
\text { Neck was the only } \\
\text { control }\end{array}$ \\
\hline \multicolumn{7}{|l|}{ Benthic studies } \\
\hline Rocky Shores & May 1968-Dec 1974 & $\begin{array}{l}\text { Visual observation } \\
\text { of a study area } \\
\text { within } 1 \mathrm{hr} \text { of low } \\
\text { tide }\end{array}$ & $\begin{array}{l}\text { Feb, May, Jul, Sep } \\
\text { and Dec }\end{array}$ & $\begin{array}{l}\text { Seven stations- } \\
\text { White Point, Fox } \\
\text { Island South, Fox } \\
\text { Island North. Giants } \\
\text { Neck and both sides } \\
\text { of Seaside Point } \\
\text { Jetty (Feb 1973-Dec 1974) }\end{array}$ & $\begin{array}{l}\text { Identification of dominant } \\
\text { organisms; relative } \\
\text { abundance estimated }+10 \%\end{array}$ & $\begin{array}{l}\text { Three control } \\
\text { stations-Giants } \\
\text { Neck and both sides } \\
\text { of Seaside Point Jetty }\end{array}$ \\
\hline $\begin{array}{l}\text { Rock substrates } \\
\text { (subtidal) }\end{array}$ & Mar 1973-Dec 1974 & 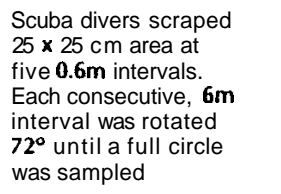 & $\begin{array}{l}\text { Mar, June, Sep, } \\
\text { Dec }\end{array}$ & $\begin{array}{l}\text { Originally } 3 \text { stations; } \\
\text { reduced to two in } \\
\text { March 1974, one near } \\
\text { Quarry, the other at } \\
\text { Giants Neck (control) }\end{array}$ & $\begin{array}{l}\text { Enumeration, identification } \\
\text { and dry weight }\end{array}$ & $\begin{array}{l}\text { Highly quantitative } \\
\text { for both plants and } \\
\text { animals }\end{array}$ \\
\hline (Intertidal) & June 1973-Dec 1974 & $\begin{array}{l}\text { Same } \approx \text { above except } \\
\text { Scuba gear not } \\
\text { needed }\end{array}$ & Same as above & $\begin{array}{l}\text { Three stations- } \\
\text { White Point; Fox } \\
\text { Island; Giants Neck } \\
\text { (control) }\end{array}$ & Same as above & \\
\hline $\begin{array}{l}\text { Sand substrates } \\
\text { (subtidal) }\end{array}$ & Mar 1973-Dec 1974 & 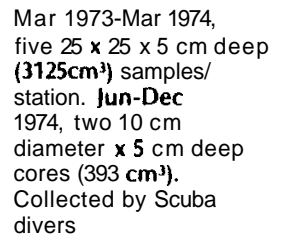 & Same as above & $\begin{array}{l}\text { Five stations- } \\
\text { JordanCove, south } \\
\text { of Quarry Cut, Two } \\
\text { Tree Island, Little } \\
\text { Rock and Bay Point. } \\
\text { Added Giants Neck } \\
\text { in Mar } 1974 \text {, and near } \\
\text { the Intake in June } 1974\end{array}$ & $\begin{array}{l}\text { Enumeration, identification; } \\
\text { largest and smallest } \\
\text { organism measured (mm) } \\
\text { and dry weight } \\
\text { determined; sand grain sire } \\
\text { measurement }\end{array}$ & \\
\hline (Intertidal) & June 1973-Jun1974 & $\begin{array}{l}\text { Same as above except } \\
\text { Scuba not needed }\end{array}$ & Same as above & $\begin{array}{l}\text { Same as rock } \\
\text { substrate (intertidal) }\end{array}$ & Same as above & \\
\hline $\begin{array}{l}\text { Lobster population } \\
\text { studies }\end{array}$ & Oct 1973-Dec 1974 & $\begin{array}{l}\text { Observation of both } \\
\text { natural and } \\
\text { artificial habitats } \\
\text { by Scuba divers } \\
\text { tagged } \mathbf{6 5 0} \text { lobsters }\end{array}$ & $\begin{array}{l}\text { Monthly observations } \\
\text { of artificial and } \\
\text { natural habitats; } \\
\text { continuous for tag } \\
\text { returns }\end{array}$ & $\begin{array}{l}\text { Seven artificial } \\
\text { and four natural } \\
\text { substrates; located } \\
\text { between Giants } \\
\text { Neck and Seaside } \\
\text { Point }\end{array}$ & $\begin{array}{l}\text { Population estimates to } \\
\text { be made }\end{array}$ & $\begin{array}{l}\text { Most of the lobsters } \\
\text { were tagged after } \\
\text { Apr } 1974\end{array}$ \\
\hline $\begin{array}{l}\text { Oyster growth } \\
\text { studies }\end{array}$ & May 1970-Dec 1974 & $\begin{array}{l}\text { Sixty tagged 2-3 yr } \\
\text { old oysters were } \\
\text { suspended on } \\
\text { plastic-coated wire } \\
\text { trays }\end{array}$ & $\begin{array}{l}\text { Feb, May, Jul, Sep } \\
\text { and Dec }\end{array}$ & $\begin{array}{l}\text { Four stations-White } \\
\text { Point. Fox Island. } \\
\text { Giants Neck (control) } \\
\text { and in the Quarry }\end{array}$ & $\begin{array}{l}\text { Length and weight } \\
\text { measurements: Mortalities }\end{array}$ & $\begin{array}{l}\text { Measurements made } \\
\text { underwater by Scuba } \\
\text { divers }\end{array}$ \\
\hline
\end{tabular}




\section{TABLE 2. Summary of Continuing Ecological Monitoring Proarams at Millstone Nuclear Power Station (continued)}

\begin{tabular}{|c|c|c|c|c|c|c|}
\hline Program & $\begin{array}{l}\text { Collection } \\
\text { Dates }\end{array}$ & $\begin{array}{l}\text { Collection } \\
\text { Method }\end{array}$ & $\begin{array}{l}\text { Sampling } \\
\text { Frequency }\end{array}$ & $\begin{array}{l}\text { Station Location } \\
\text { and Number }\end{array}$ & Analyses Performed & Remarks \\
\hline $\begin{array}{l}\text { Trace metal analysis } \\
\text { water }\end{array}$ & Sep 1971-Dec 1974 & $\begin{array}{l}\text { Grab sample of } \\
\text { surface sea water }\end{array}$ & Same as above & $\begin{array}{l}\text { Four stations- } \\
\text { Quarry. Two-Tree } \\
\text { Channel, Intake and } \\
\text { Giants Neck (control) }\end{array}$ & $\begin{array}{l}\text { Atomic absorption } \\
\text { spectrophotometry-lead, } \\
\text { iron chromium, zinc. } \\
\text { copper }\end{array}$ & \\
\hline $\begin{array}{l}\text { Oyster and mussel } \\
\text { tissue }\end{array}$ & Same as above & $\begin{array}{l}\text { Oysters from trays } \\
\text { and mussels from } \\
\text { natural beds }\end{array}$ & $\begin{array}{l}\text { May and Wep (Sep 1971- } \\
\text { Sep 1973). Feb, May, } \\
\text { lul, Sep and Dec (May } \\
\text { 1973-Drc 1974) }\end{array}$ & $\begin{array}{l}\text { Three stations-Two } \\
\text { in Plume Path (Quaarry } \\
\text { and Fox Island) and } \\
\text { Giants Neck (control) }\end{array}$ & $\begin{array}{l}\text { Atomic absorption } \\
\text { spectrophotometry-lead, } \\
\text { iron, chromium, zinc, } \\
\text { copper }\end{array}$ & \\
\hline \multicolumn{7}{|l|}{ Fish studies } \\
\hline Shore zone fish & May 1969-Dec 1974 & $\begin{array}{l}\text { Three adjacent } 30 \mathrm{~m} \\
\text { haul/station with } \\
9.1 \mathrm{~m} \times 1.2 \mathrm{~m} \text { bag seine } \\
\text { (6mm mesh) }\end{array}$ & $\begin{array}{l}\text { Feb, May, Jul, Sep, } \\
\text { Dec (May 1969-Dec 1973) } \\
\text { Feb, May. June, Jul, Aug. } \\
\text { Sep, Oct. Dec (feb- } \\
\text { Dec 1974) }\end{array}$ & $\begin{array}{l}\text { May 1969-Dec 1972, } \\
\text { Four stations- } \\
\text { (White Point, Jordan } \\
\text { Cove, Bay Point, and } \\
\text { Giants Neck). From } \\
\text { Feb 1973, Seaside } \\
\text { Point and Black Point } \\
\text { added }\end{array}$ & $\begin{array}{l}\text { Enunlerdtion, identification, } \\
\text { species diversity and } \\
\text { ranking by relative } \\
\text { abundance }\end{array}$ & $\begin{array}{l}\text { Aliquots measured } \\
\text { from large samples }\end{array}$ \\
\hline Gill netted fish & Dec 1971-Dec 1974 & $\begin{array}{l}\text { Gill nets set overnight, } \\
\text { net made of } 6-25^{\prime} \text { panels } \\
\text { of } 2^{\prime \prime} .11 / 4^{\prime \prime}, 1^{\prime \prime} .3 / 4^{\prime \prime} \text {, } \\
11 / 2^{\prime \prime} \text { and } 21 / 2^{\prime \prime} \text { mesh }\end{array}$ & $\begin{array}{l}\text { Dec 1971-May 1973, } \\
\text { quarterly. June 1973- } \\
\text { Dec 1974, himonthly. } \\
\text { Jan1974-Dec } 1974 . \\
\text { monthly }\end{array}$ & $\begin{array}{l}\text { Dec 1971-May 1973, } \\
\text { two stations (near } \\
\text { Two-Tree Island and } \\
\text { Bay Point). lune 1973- } \\
\text { Dec 1974, two stations } \\
\text { added (Black Point } \\
\text { and Jordan Cove) }\end{array}$ & $\begin{array}{l}\text { Enumerat onidentification, } \\
\text { standard length and relative } \\
\text { abundance }\end{array}$ & $\begin{array}{l}\text { Sampling frequency } \\
\text { increase to take } \\
\text { measure of spring and } \\
\text { fall migrations }\end{array}$ \\
\hline Irawl netted fish & Apr 1973-Dec 1974 & $\begin{array}{l}\text { 9.1m otter trawl } \\
\text { with } 6 \mathrm{~mm} \text { cod end liner, } \\
\text { towed for } 15 \mathrm{~min}\end{array}$ & Biweekly & $\begin{array}{l}\text { Eight stations with } \\
\text { Iwo controls } \\
\text { (Niantic Bay and } \\
\text { Long Island Sound) }\end{array}$ & $\begin{array}{l}\text { Enumerat onidentifiration, } \\
\text { wet weight and total length }\end{array}$ & $\begin{array}{l}\text { Invertebrates collected } \\
\text { were also counted }\end{array}$ \\
\hline Fish tagging & Mar 1983-Dec 1974 & $\begin{array}{l}\text { Gill nets, otter trawls } \\
\text { and trap nets, tagged } \\
3 \text { species (winter } \\
\text { flounder, windowpane } \\
\text { flounder and tautog) }\end{array}$ & Continuous & $\begin{array}{l}\text { No particular } \\
\text { stations }\end{array}$ & $\begin{array}{l}\text { Used Jolley's rnethod for } \\
\text { population estimates based } \\
\text { on mark-recapture datd }\end{array}$ & $\begin{array}{l}\text { Tag returns from } \\
\text { otter trawling and } \\
\text { from sport and } \\
\text { commercial catch }\end{array}$ \\
\hline $\begin{array}{l}\text { Fish stomach } \\
\text { content andysis }\end{array}$ & Jun 1973-Nov 1974 & $\begin{array}{l}\text { Same } \approx \text { trawl netted } \\
\text { fish }\end{array}$ & Monthly & $\begin{array}{l}\text { Same as trawl } \\
\text { nette }\end{array}$ & $\begin{array}{l}\text { Stomachs first ranked } \\
\text { according to fullness, then } \\
\text { contents were identified } \\
\text { and counted }\end{array}$ & $\begin{array}{l}\text { Stomachs came from } \\
\text { otter trawl netted } \\
\text { fish }\end{array}$ \\
\hline $\begin{array}{l}\text { I hithyoplankton } \\
\text { and zooplankton }\end{array}$ & Mdy 1973-Dec 1974 & $\begin{array}{l}\text { Bongo nets- } \sim 1 / 2 \text { and } \\
1 / 3 \mathrm{~mm} \text { mesh, } \mathbf{0 . 6 m} \\
\text { mouth diameter. } 15 \\
\text { min. Oblique tow } \\
\text { filtering } \sim 200 \mathbf{m}^{3}\end{array}$ & $\begin{array}{l}\text { Very complex, but } \\
\text { generally: All station } \\
\text { weekly, every 4th week } \\
\text { night tows and } \\
\text { stratified surface } \\
\text { and bottom tows at } \\
1 / 2 \text { of all stations } \\
\text { every other week. }\end{array}$ & $\begin{array}{l}\text { Fourteen stations } \\
\text { throughout } \\
\text { surrounding area }\end{array}$ & $\begin{array}{l}\text { Enumerdtion and } \\
\text { identification }\end{array}$ & $\begin{array}{l}\text { Ichthyo and zoo- } \\
\text { plankton samples were } \\
\text { collected side by side } \\
\text { also measured } \\
\text { temperdture, salinity, } \\
\text { pH and D.O. at surface } \\
\text { and bottom }\end{array}$ \\
\hline
\end{tabular}




\section{TABLE 3. Summary of Special Ecological Studies (Entrainment, Impingement, etc.) at Millstone Nuclear Power Station}

\begin{tabular}{|c|c|c|c|c|c|c|}
\hline PROGRAM & $\begin{array}{l}\text { COLECTION } \\
\text { DATES }\end{array}$ & $\begin{array}{l}\text { COLECTION } \\
\text { METHOD }\end{array}$ & FREQUENCY & $\begin{array}{l}\text { STATIONLOCATION } \\
\text { AND NUMBER }\end{array}$ & ANALYSES PERFORMED & REMARKS \\
\hline $\begin{array}{l}\text { ENTRAINMENT STUDIES } \\
\text { ZOOPLANKTON }\end{array}$ & NOV 1970 - NOV 1971 & $\begin{array}{l}0.5 \text { m NET WITH0.33 } \\
\text { MESH FORM min. AT } \\
3 \text { m DEPTH. } \\
\text { DUPLICATE TOWS } \\
\text { MADE }\end{array}$ & BIWEEKLY & $\begin{array}{l}\text { THREE STATIONS - INTAKE. } \\
\text { DISCHARGE TO QUARRY } \\
\text { AND QUARRY CUT }\end{array}$ & $\begin{array}{l}\text { SEASONALITY; MORTALITY RATES } \\
\text { BY VITAL STAINING UNDER } \\
\text { FOLIOWING CONDITIONS: HEAT } \\
\text { ALONE. HEAT AND CHLORINE. NO } \\
\text { HEAT AND NO CHLORINE AND } \\
\text { CHLORINE ALONE: SINKING RATES: } \\
\text { AND OELAYED MORTALITIES BY } \\
\text { PLACING ENTRAINED COPEPODS } \\
\text { IN PLASTIC BAGS AND HOLDING } \\
\text { THEM IN M EQUARRY AND AT } \\
\text { JORDAN COVE (CONTROL) }\end{array}$ & $\begin{array}{l}\text { BOTH DAY AND NIGHT } \\
\text { REPLICATES WERE COLLECTED } \\
\text { FOR DIURNAL DIFFERENTIA- } \\
\text { TION. PUNT HAD TO BE } \\
\text { OPERATING AT DESIRED MODE } \\
\text { FOR A MINIMUM OF48 hr. } \\
\text { BEFORE SAMPLING }\end{array}$ \\
\hline ZOOPLANKTON & $\begin{array}{l}\text { NOV 1971- OCT1972 } \\
\text { MAR 1974- FEB } 1975\end{array}$ & $\begin{array}{l}0.5 \mathrm{~m} \text { NET WITH } 0.33 \\
\text { MESH FOR } 20 \mathrm{~mm} \text { AT } \\
3 \mathrm{~m} \text { DEPTH }\end{array}$ & $\begin{array}{l}\text { SAMEAS } \\
\text { ABOVE }\end{array}$ & $\begin{array}{l}\text { ONE STATION AT INTAKE } \\
\text { ONLY }\end{array}$ & $\begin{array}{l}\text { ENUMERATION AND } \\
\text { IDENTIFICATION }\end{array}$ & $\begin{array}{l}\text { A TWO CYCLE } 22 \text { VEARS APART } \\
\text { STUDY TO DETERMINE COPE- } \\
\text { POD SEASONALITY }\end{array}$ \\
\hline $\begin{array}{l}\text { PHYTOPLANKTON } \\
\text { CHLORINE AND } \\
\text { PRODUCTIVINY }\end{array}$ & JUL 1971- DEC 1971 & $\begin{array}{l}1 \text { I OF SEAWATER } \\
\text { BY VAN DORN BOTLE } \\
\text { AT3 } \mathrm{m} \text { (INTAKE) AND } \\
\text { I } \mathrm{m} \text { DEPTHS }\end{array}$ & $\begin{array}{l}\text { INTERMITIENT } \\
\text { DEPENDING ON } \\
\text { CHLORINE INJECTION }\end{array}$ & $\begin{array}{l}\text { THREE STATIONS - INTAKE. } \\
\text { OUARRY AND OUARRY } \\
\text { OUTLET }\end{array}$ & $\begin{array}{l}\text { PRODUCTIVITY BY TH: }{ }^{14} \mathrm{C} \text { LIGHT- } \\
\text { DARK BOTLE METHOD }\end{array}$ & $\begin{array}{l}\text { CHLORINE LEVEI VARIED } \\
\text { BETMEEN 0 - L.2 DOM }\end{array}$ \\
\hline $\begin{array}{l}\text { TEMP. AND } \\
\text { PRODUCTIVITY }\end{array}$ & MAR 191- R B 1972 & SAME AS ABOM & SAME AS ABOM & SAME AS ABOM & SAME AS ABOVE & \\
\hline $\begin{array}{l}\text { TEMP. ANO } \\
\text { STANDINGCROP }\end{array}$ & MAR 1971- JUN 1971 & SAME AS ABOM & $\begin{array}{l}\text { SEVEN DATES. } \\
\text { DUPLICATE SAMPLES }\end{array}$ & $\begin{array}{l}\text { INTAKE AND QUARRY } \\
\text { OUTLET }\end{array}$ & $\begin{array}{l}\text { ENUMERATION AND IDENTIFICA- } \\
\text { TION }\end{array}$ & \\
\hline LOBSTER LARVAE & APR 1974－DEC 1974 & $\begin{array}{l}1 \mathrm{~m} \text { NET WITH } 0.33 \mathrm{~mm} \\
\text { MESH FOR } 20 \text { min. } \\
\text { BOTH DAY AND NIGHT }\end{array}$ & WEEKLY & $\begin{array}{l}\text { ONE STATION AT THE } \\
\text { DISCHARGE TO THE } \\
\text { QUARRY }\end{array}$ & ENUMERATION & $\begin{array}{l}\text { NET POSIT IONED IN FAST } \\
\text { MOVING WATER TO PREMNT } \\
\text { NET AVOIDANCE }\end{array}$ \\
\hline ICHR-YYOPLANKTON & NOV 1970- SEP 1974 & $\begin{array}{l}\text { SAME AS } \\
\text { ZOOPLANKTON }\end{array}$ & BIWEEKLY & SAME AS ZOOPLANKTON & $\begin{array}{l}\text { ENUMERATION, IOENTIFICATION } \\
\text { ANO SURVIVAL IHELD LIVE FISH } \\
\text { FOR } 24 \mathrm{hr} \text {. TO MEASURE DELAYED } \\
\text { MORTALITY) }\end{array}$ & $\begin{array}{l}\text { TAKEN CONCURRENTLWWITH } \\
\text { ZOOPLANKTON }\end{array}$ \\
\hline $\begin{array}{l}\text { TEUP. AND } \\
\text { FISH LARVAE }\end{array}$ & UNKNOWN & UNKNOWN & UNKNOWN & $\begin{array}{l}\text { CQLLECIED FISH LARVAE } \\
\text { FROM NIANTIC BAY AND } \\
\text { JORDAN COVE }\end{array}$ & $\begin{array}{l}\text { LABORATORY TESTS TO DETERMINE } \\
\text { CRITICAL TEMPERATURE MAXIMUMM } \\
\text { FOR } 3 \text { SPECIES: ATLANTIC } \\
\text { SILVERSIDE. WINTER ROUNDER } \\
\text { AND KILIIFISH }\end{array}$ & $\begin{array}{l}\text { WATER TEMPERATURE } \\
\text { RAISED } \sim 1^{\circ} \mathrm{C} / \mathrm{min} .\end{array}$ \\
\hline IMPINGEMENT & JAN 1972 - DEC 1974 & $\begin{array}{l}\text { SCREEN WASHING } \\
\text { INTO TRASH BASKET }\end{array}$ & $\begin{array}{l}\text { DAILY (1972 - JUN 1973) } \\
\text { WWICE IDAY (JUL 1973- } \\
\text { JUN 1974 ON FOUR DAYI } \\
\text { WEEK }\end{array}$ & INTAKE SCRWS & $\begin{array}{l}\text { ENUMERATION AND } \\
\text { IDENTIFICATION; FROM JAN } 1973 \\
\text { ALL ORGANISMS SORTED INTO } \\
0-3.3-6 \text { AND 6" ANO OVER } \\
\text { SIZE CATEGORIES }\end{array}$ & \\
\hline $\begin{array}{l}\text { WINTER FLOUNDER } \\
\text { ENTRAINMENT MOOEL }\end{array}$ & \multicolumn{6}{|c|}{$\begin{array}{l}\text { IN M I S MODEL PLANT INDUCED MORTALITY IS CONSIDERED YPARATELY FROM NATURAL MORTALITY: THUS THE COMPENSATION OF NATURAL MORTALIIT FOR } \\
\text { ENTRAINMENT MORTALITY IS IGNORED. THEREFORE IF NATURAL MORTALITY IS DENSITY DEPENDENT. ENTRAINMENT MORTALITY WILL BE OVERESTIMATED. } \\
\text { OTHERWISE M E RESULTS WOULD BE M E SAME AS IF THE TWO WERE CONSIDERED TOGETHER }\end{array}$} \\
\hline WATER QUALITY & \multicolumn{6}{|c|}{ 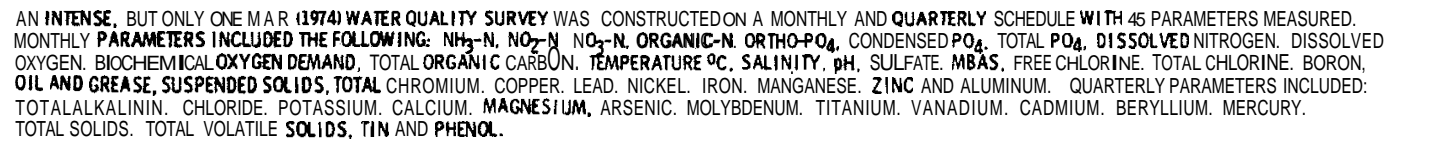 } \\
\hline
\end{tabular}


continuous from November 1970 through September 1974. Thus, the individual effects of temperature, chlorine and mechanical stress were determined as well as the synergistic effects over varying periods of time.

In addition to entrainment and impingement studies, a winter flounder entrainment model was developed. This model was based on a tidal circulation model of Niantic Bay and its surrounding area. Plant-induced mortality was considered separately from natural mortality and, thus, tends to overestimate entrainment mortality. Because density-dependent natural mortality was ignored, it does not compensate for plant mortalities.

A 1 yr water quality monitoring program was conducted in 1974 on a monthly and quarterly schedule at nine locations. The following parameters were monitored monthly: $\mathrm{NH}_{3}-\mathrm{N}, \mathrm{NO}_{2}-\mathrm{N}, \mathrm{NO}_{3}-\mathrm{N}$, organic-N, or tho $\mathrm{PO}_{4}$, condensed $\mathrm{PO}_{4}$, total $\mathrm{PO}_{4}$, dissolved $\mathrm{N}$, dissolved $\mathrm{O}, \mathrm{BOD}$, TOC, temperature $\left({ }^{\circ} \mathrm{C}\right)$, salinity, $\mathrm{pH}, \mathrm{SO}_{4}, \mathrm{MBAS}$, free-Cl, total-Cl, B, oil and grease, $\mathrm{SS}, \mathrm{Cr}, \mathrm{Cu}, \mathrm{Pb}, \mathrm{Ni}$, $\mathrm{Fe}, \mathrm{Mn}, \mathrm{Zn}$ and $\mathrm{A}$. Quarterly samples included: total al kal inity, chloride, $\mathrm{K}, \mathrm{Ca}, \mathrm{Mg}$ As, Mo, Ti, V, Cd, Be, Hg, Zn, total solids, total volatile solids, and phenol. In addition to the above parameters, sediment samples were collected on a quarterly basis and analyzed for the following: total- $\mathrm{N}$, total- $\mathrm{PO}_{4}$, TOC, TVS, B, Al, $\mathrm{Fe}, \mathrm{Cu}, \mathrm{Ni}, \mathrm{Pb}, \mathrm{Hg}$, $\mathrm{Zn}, \mathrm{Be}, \mathrm{Cd}, \mathrm{V}, \mathrm{Ti}, \mathrm{Mo}, \mathrm{Mn}, \mathrm{As}, \mathrm{Cr}$, oil and grease, and phenols. Monthly samples were collected on both ebb and flood tides with a Van Dorn water sampler while a core sampler was used for obtaining sediment samples. The stations were sampled at the maximum of each tide. For example, Stations 4 and 8 were influenced by the thermal plume on the flood tide, and thus, were sampled at the maximum of the flood tide.

Figure 3 is a composite of the ecological monitoring program sampling locations. Sites for specific programs are designated in the legend. 


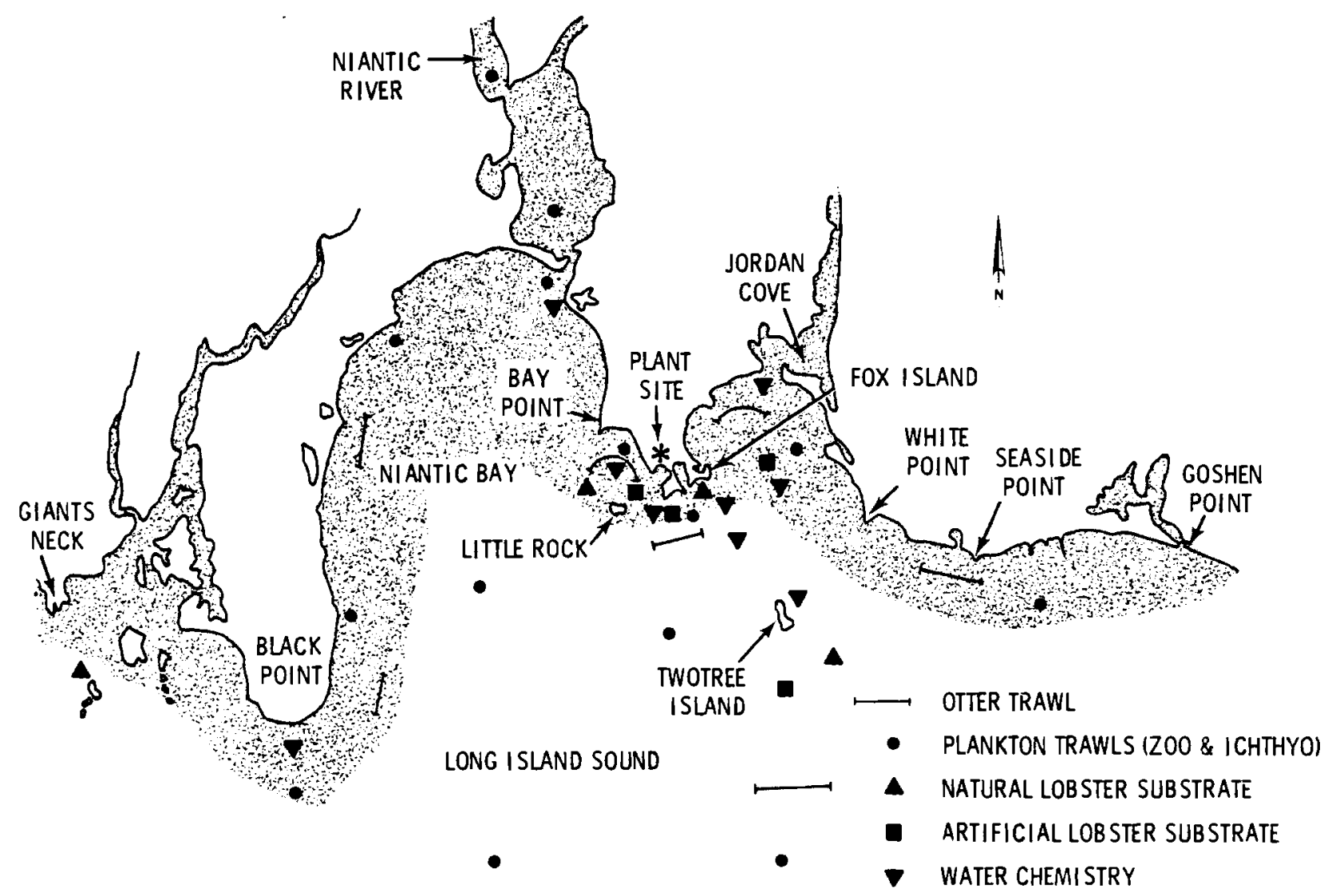

FIGURE 3. Composite of the Ecological Sampling Stations at Millstone Nuclear Power Station 
VI. PREDICTED IMPACTS AND TECHNICAL SPECIFICATIONS 


\section{PREDICIED IMPACIS AND TBCHNICAL SPECIFICATIONS}

The final, Environmental Technical Specifications for Millstone, Unit 1 were published by NRC on 19 December 1975. This nuclear power plant began commercial operation in November 1970 with aquatic ecology studies beginning in 1968 and continuing to date. Thus, about 2-1/2 yr of preoperational and $5 \mathrm{yr}$ of operational data have been collected before final Tech Specs were approved. However, this situation probably existed because the plant was back-fitted with an environmental impact statement to satisfy the intent of NEPA.

The final Tech Specs (NRC, 1975) points out that the ecological programs conducted at Millstone have produced a large body of information prior to plant operation with additional data on the impact of Unit 1. This document also points out that the present ecological program provides "reasonable assurance that both the short and long-range changes which might result from the operation of multiple units can be detected and evaluated." The final Tech Specs, therefore, call for a continuation of the present ecological monitoring program. This includes about ten separate programs with additional special surveillance studies. For an overall summary of these programs, refer to Tables 2 and $\mathbf{3}$ of this report.

Predicted ES impacts for Millstone include: 1) loss of planktonic organisms through entrainment, 2) loss of organisms through impingement, 3) potential for fish kills in the discharge quarry, and 4) creation of a thermal plume covering up to 44.5 hectares. The final Tech Specs address these predicted impacts and include many additional studies. The Tech Specs, thus, call for a more demanding monitoring program than the FES predicted, in terms of potential impacts. The reason for such a rigorous monitoring program is that multiple units are planned for Millstone. It appears that the monitoring programs, which began in 1968 and since have been modified (1972 and 1973), meet the objective of this study. These objectives are to evaluate the potential impacts of Unit 1 and provide a sufficient data base for the construction and operation of additional units. 
Since the Tech Specs call for broad coverage of the aquatic ecosystem, actually more than the ES predicted, certain questions arise. Ho quantitative are these present and past monitoring programs? How much useful data was and will be collected and evaluated with the present state-of-the-art knowledge about environmental impacts?

Instead of attempting to sample the entire aquatic ecosystem for potential changes, which may or may not be detrimental, monitoring programs perhaps should be implemented focussing on important species or communities. With this in mind, more consideration should be given to a sampling design, that is statistically oriented in order to try to differentiate between natural variation at a station, between stations, between years and plant-induced effects. 
VII. RATIONALE FOR DATA SYNTHESIS 


\section{RATIONALE FOR DATA SYNTHESIS}

More than twenty separate ecological monitoring programs have been conducted for $8 \mathrm{yr}$ at the Millstone site. Some populations have been extensively monitored (1968-1974), while others have been short-term (1 yr or less). Thus, data recording and synthesis for statistical analyses were a very important and sometimes cumbersome aspect of this study. However, due to certain inconsistencies (e.g., adding and/or deleting sampling stations from year to year, changing sampling programs, changing sampling methodologies and reporting formats) not all of the data collected could be quantitatively evaluated. Therefore, we present here the rationale for our choices whereby selected data sets were used for subsequent statistical analysis and the reasons why others were not evaluated.

\section{STUDIES EVALUATED}

We statistically evaluated studies when several or all of the following criteria were met:

- Both preoperational and operational data sets were collected.

- At least one control station was sampled.

- Several samples were collected each year at each station.

- Sampling stations and methodologies were consistent from year-to-year.

- Data collections were quantitative in nature.

The following studies met the above criteria and were analyzed in detail: boring and fouling organisms (exposure panel), oyster growth, trace metals in seawater and their concentration levels in oyster and mussel tissue and shorezone fish. In addition to the above, two programs that were terminated in 1973 (barnacle populations and intertidal sand infauna) also met the aforementioned criteria, and thus were evaluated.

Several other studies were evaluated because of their uniqueness, commonality, and/or mention of a statistical analysis performed by the applicant. For example, the Rocky Shore Community Study was highly qualitative 
because all organisms were classified by their relative abundance (visual observation). However, this study was conducted from May 1968 through December 1974. It was one of the longest, in terms of years of data collected, and best from the standpoint of consistent data collection methodology. Although the impingement study can only be conducted during operation, we evaluated the study because of its potential for environmental impacts and the interest shown by all parties concerned (commonality). Entrainment studies were evaluated for similar reasons, however, not all of the entrainment studies received detailed analyses. There were eight separate studies but we analyzed two--zooplankton and ichthyoplankton. Zooplankton were evaluated for seasonality, mortality (heat, chlorine and mechanical stresses - individual and combined effects) and delayed mortality. Ichthyoplankton were assessed for immediate and delayed mortality.

\section{STUDIES NOT EVALUATED}

Four monitoring programs were terminated between 1970 and 1973 either because the results were not quantifiable or they lacked consistency. However, these programs were replaced by more quantitative studies in 1973. The terminated programs included: plankton survey (May 1969 to September 1972), lobster survey (July 1968 to March 1973), lobster pot survey (February 1969 to May 1973) and the oyster seed growth study (August 1968 to February 1970).

Other programs not evaluated were either replacement studies for the terminated studies, or change-of-direction studies to examine a new dimension in the surrounding aquatic ecosystem. Replacement studies include: lobster population measurements, ichthyoplankton and zooplankton surveys of the surrounding area, and benthic surveys (intertidal, subtidal rock and sand substrates). Otter trawling for demersal fish, gill netting and subsequent fish stomach content studies are examples of change-of-direction studies. The above studies were not evaluated either because of paucity of available data or lack of preoperational data sets to compare to operational and/or lack of consistency in station locations. For example, during both the benthic and gill-netting studies the number of stations increased or decreased between March 1973 and December 1974. Attempts to accumulate data sets for analyses were quite arduous. 
As mentioned above, only two out of several entrainment studies were analyzed in detail. Those studies not evaluated include: phytoplankton; the effects of chlorine, heat and mechanical stress (individual and combined) on standing crop and productivity; Iobster larvae; one zooplankton study; and a two-cycle study for which the final data are unavailable. The phytoplankton studies were not evaluated because the results were similar to those of zooplankton, which were evaluated (i.e., samples were simultaneous). Lobster larvae entrainment was not evaluated because no larvae were entrained. The second two-cycle zooplankton study is still awaiting completion, and, therefore, cannot be evaluated.

An intense, $1 \mathrm{yr}$ water quality study was conducted in 1974 on a monthly and quarterly schedule. Approximately 45 parameters were measured including water column and sediment characteristics for some parameters. However, without preoperational baseline conditions, we could only compare these measurements to themselves and so this study was not evaluated. 
VIII. ANALYSIS OF THERMAL MONITORING PROGRAMS 


\section{ANALYSIS OF THERMAL MONITORING PROGRAMS}

\section{NONECOLOGICAL THERMAL MONITORING}

Monitoring associated with temperature, tidal levels and currents has been conducted since 1966. Much of the data gathered in these monitoring efforts have, however, been gathered only in the last few years, after Unit 1 became operational. The monitoring has been conducted in several programs by several different monitoring groups. A summary of the nonecological hydrological monitoring programs is presented in Table 4 . Included in this table are the parameters measured, the duration of the monitoring, the dates of program initiation and other pertinent information that could be gathered from the available information.

When considering the hydrologic monitoring for this plant, it should be remembered that much of the monitoring was performed after the plant began operation. The emphasis of the monitoring was to provide calibration and verification for models used prior to operation and those planned for use before Units 2 and 3 begin operation. It is fortuitous that one of the three nuclear generating stations examined in this monitoring review geared its monitoring to hydrodynamic and ecological models. This gives a unique opportunity to evaluate the success or failure of this type of monitoring program direction.

An examination of the material displayed in Table 4 shows that the temperature monitoring was almost exclusively of the survey type. Only one program provided temperature information at several locations in the plant vicinity with any regularity, that being data obtained by Northeast Utilities Services Company (NUSCo). The information gathered by NUSCo is for eight shoreline stations extending from Niantic Bay Yacht Club on the west shore of Niantic Bay to the east side of Jordan Cove, at White Point. Five of the eight stations were located within $500 \mathrm{yd}$ of the Unit 1 outfall. Only one of these five, Millstone Cove Point, provided preoperational data. It is unlikely that the temperatures reported for Niantic Bay Yacht Club, 


\section{TABLE 4. Summary of Nonecological Hydrology Monitoring Programs}

\begin{tabular}{|c|c|c|c|c|c|c|}
\hline DATES & PARAMETERS & $\begin{array}{l}\text { SAMPLING } \\
\text { STATIONS }\end{array}$ & FREQUENCY & REPORTING FORMAT & PERFORMER & COMMENTS \\
\hline 1966 - PRESENT & TEMPERATURE & $\begin{array}{l}\text { 8- SHORELINE } \\
\text { STATIONS }\end{array}$ & UNKNOWN & $\begin{array}{l}\text { GRAPH OF WEEKLY MEAN } \\
\text { BOUNDED BY RANGE }\end{array}$ & NUSCO & $\begin{array}{l}\text { ONLY ONE MONITORING } \\
\text { STATION IN REGION OF } \\
\text { DISCHARGE HAS RESULTS } \\
\text { BEFORE PLANT } \\
\text { OPERATION BEGINS }\end{array}$ \\
\hline MAY $8-20,1966$ & DYE CONCENTRATION & $\begin{array}{l}\text { SURVEY - TRANSECTS } \\
\text { UNKNOWN. VERTICAL } \\
\text { SAMPLING BUT NO } \\
\text { RESULTS OR DATA } \\
\text { GIVEN }\end{array}$ & UNKNOWN & $\begin{array}{l}\text { TEST DISCUSSION OF } \\
\text { RESULTS AND SCHEMATIC } \\
\text { OF PLUME ATEND OF } \\
\text { FLOOD AND EBB TIDES }\end{array}$ & $\begin{array}{l}\text { PRITCHARD-CARPENTER } \\
\text { CONSULTANTS }\end{array}$ & $\begin{array}{l}\text { DYE WAS INTRODUCED } \\
\text { OUTSIDE OF QUARRY WITH } \\
\text { NO CIRCULATING WATER } \\
\text { DISCHARGE. DURATION } \\
\text { OF SURVEY UNKNOWN }\end{array}$ \\
\hline FEB. 1970 & DYE CONCENTRATION & $\begin{array}{l}\text { SURVEY-TRANSECTS } \\
\text { UNKNOWN. VERITICAL } \\
\text { SAMPLING BUT NO } \\
\text { DATA OR RESULTS } \\
\text { GIVEN }\end{array}$ & UNKNOWN & $\begin{array}{l}\text { TEST DISCUSSION Of } \\
\text { DYE DISTRIBUTION AND } \\
\text { SCHEMATIC OF PLUME AT } \\
\text { END OF FLOOD TIDE ON } \\
\text { A WINDY DAY }\end{array}$ & $\begin{array}{l}\text { PRITCHARDCARPENTER } \\
\text { CONSULTANTS }\end{array}$ & $\begin{array}{l}\text { DYE I N DISCHARGE TO } \\
\text { QUARRY WITH NON- } \\
\text { BUOYANTCIRCULATING } \\
\text { WATER. I.E NOT HEATED. } \\
\text { DURATION OF SURVEY } \\
\text { UNKNOWN }\end{array}$ \\
\hline AUG 29. $1 \% 8$ & $\begin{array}{l}\text { TEMPERATURE } \\
\text { SALINITY }\end{array}$ & $\begin{array}{l}3 \text { - STATIONS IN } \\
\text { EXPECTED REGION } \\
\text { OF THE PLUME, } \\
\text { EXACT LOCATION } \\
\text { UNKNOWN. VERTICAL } \\
\text { PROFILES TAKEN }\end{array}$ & -HOURLY & $\begin{array}{l}\text { PLOTS OF TEMPERATURE } \\
\text { AND SALINITY WITH } \\
\text { DEPTH ATEACH STATION. } \\
\text { TABULATED DATA }\end{array}$ & RAYTHEON CORPORATION & $\begin{array}{l}\text { MAXIMUM TEMPERATURE } \\
\text { AND SALINITY } \\
\text { DIFFERENCES BETWEEN } \\
\text { SURFACE AND } 7.6 \mathrm{~m} \text { DEPTH } \\
\text { WERE } 0.7^{\circ} \mathrm{C} \text { AND } 0.2 \text { ppt., } \\
\text { RESPECTIVELY }\end{array}$ \\
\hline MAR 20, 1969 & $\begin{array}{l}\text { TEMPERATURE } \\
\text { SALINITY }\end{array}$ & $\begin{array}{l}3 \text { - STATIONS IN } \\
\text { EXPECTED REGION } \\
\text { OF M E PLUME- } \\
\text { VERTICAL PROFILES } \\
\text { TAKEN }\end{array}$ & $\sim$ HOURLY & $\begin{array}{l}\text { PLOTS OF TEMPERATURE } \\
\text { AND SALINITY WITH } \\
\text { DEPTH AT EACH STATION. } \\
\text { TABULATED DATA }\end{array}$ & RATHEON CORPORATION & $\begin{array}{l}\text { MAXIMUM TEMPERATURE } \\
\text { AND SALINITY } \\
\text { DIFFERENCES BETWEEN } \\
\text { SURFACE AND } 7.6 \mathrm{~m} \text { DEPTH } \\
\text { WERE } 1.7^{\circ} \mathrm{C} \text { AND } 1.1 \mathrm{ppt.} \\
\text { RESPECTIVELY }\end{array}$ \\
\hline
\end{tabular}

* NUSCO - NORTHEAST UTILITIES SERVICES COMPANY

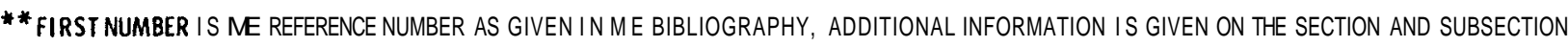


TABLE 4. Summary of Nonecological Hydrology Monitoring Programs (Continued)

\begin{tabular}{|c|c|c|c|c|c|c|}
\hline DAES & PARAMETERS & $\begin{array}{l}\text { SAMPLING } \\
\text { STATIONS } \\
\end{array}$ & FREQUENCY & REPORTING FORMAT & PERFORMER & COMMENTS \\
\hline JUNE 14 - 20, 1971 & TEMPERATURE & $\begin{array}{l}\text { SURVEY - IRANSECTS } \\
\text { IN HORIZONTAL, } \\
\text { VERTICAL PROFILES }\end{array}$ & $\begin{array}{l}\text { ONE FOR EACH TIDAL } \\
\text { CONDITION }\end{array}$ & $\begin{array}{l}\text { PLOTS OF VERTICAL } \\
\text { EMPERANRE PROFILES } \\
\text { ATEACH STATION, PLOTS } \\
\text { OF M E HORIIONTAL } \\
\text { SURFACE TEMPERATURES } \\
\text { FOR EACH TIDAL } \\
\text { CONDITION }\end{array}$ & VAST INC & $\begin{array}{l}\text { SURVEY DESIGN. TECHNIQUES } \\
\text { AND EQUIPMENT WERE } \\
\text { DISCUSSED AND DETAILED. DATA } \\
\text { WERE OFFERED I N DETAIL. } \\
\text { DISCUSSION OF M E RESULTS } \\
\text { WAS INFORMATIVE. DURATION } \\
\text { OF SURVEYS UNKNOWN. } \\
\text { PROBABLY ABOUT } 3 \text { hrS }\end{array}$ \\
\hline $\begin{array}{l}\text { SEP } 22 \text { AND } 3 \\
\text { WEEKS I N NOV, } \\
1971\end{array}$ & $\begin{array}{l}\text { CURRENT 12 STATIONS). } \\
\text { PH. SALINITY, } \\
\text { TEMPERATURE, DYE } \\
\text { CONCENTRATION AND } \\
\text { TURBIDITY }\end{array}$ & $\begin{array}{l}\text { SURVEYS ISEE FIGURE } \\
\text { C, D AND E IN } \\
\text { HORIZONTAL AND } \\
\text { VERTICAL }\end{array}$ & $\begin{array}{l}\text { SAMPLING TIMES } \\
\text { REPORTED. NOT AT } \\
\text { REGULAR INTERVALS }\end{array}$ & $\begin{array}{l}\text { TABULATION OF ALL } \\
\text { TEMPERATUREAND DYE } \\
\text { CONCENTRATION, } \\
\text { CURRENTS, WIND AND } \\
\text { TIDAL HEIGHTS }\end{array}$ & VAST INC. & $\begin{array}{l}\text { PROJECT PERFORMED I N TWO } \\
\text { PARTS. DYE WAS INTRODUCED } \\
\text { INFO DISCHARGE TO QUARRY } \\
\text { IN PART ONE AND MONITORED } \\
\text { IN THE OCEAN WATERS: THE } \\
\text { SECONDEMPLOYED } 5 \text { RAFTS I N } \\
\text { WO- REE CHANNEL WITH DYE } \\
\text { DISCHARGE FROM EACH. } \\
\text { SURVEY DESIGN, TECHNIQUES } \\
\text { AND EQUIPMENT WERE } \\
\text { DISCUSSED. EACH SURVEY } \\
\text { TOO. FROM } 2 \text { TO } 31 / 2 \text { hrS }\end{array}$ \\
\hline $\begin{array}{l}\text { AUG } 8 \text { - SEP } 10 . \\
1973\end{array}$ & CURRENT TIDE LEVEL & $\begin{array}{l}5 \text { TIDE LEVEL } \\
12 \text { CURRENT METERS } \\
\text { 12/LOCATION) }\end{array}$ & $\begin{array}{l}\text { EVERY } 20 \mathrm{~min} . \\
\text { EVERY } 10 \mathrm{~min} .\end{array}$ & $\begin{array}{l}\text { A PLOT REPRESENTATIVE } \\
\text { OF DATA }\end{array}$ & BRAINCON & $\begin{array}{l}\text { PATA GATHERED WERENOT } \\
\text { PRESENTED T ANY FORM. } \\
\text { DISCUSSION INCLUDES } \\
\text { EQUIPMENT SPECIFICATIONS } \\
\text { AND CHRONOLOGICAL } \\
\text { DESCRIPTION OF INSTALLATION }\end{array}$ \\
\hline FEB 6 - 20, 1974 & CURRENT TIDE LEVEL & $\begin{array}{l}7 \text { TIDELEVEL } \\
18 \text { CURRENT METERS } \\
\text { (2/LOCATION) }\end{array}$ & EVERY $20 \mathrm{~min}$ & $\begin{array}{l}\text { A PLOT REPRESENTATIVE } \\
\text { OF DATA }\end{array}$ & BRAINCON & $\begin{array}{l}\text { DATA GATHERED WERENOT } \\
\text { PRESENTED I N ANY FORM. } \\
\text { DISCUSSION INCLUDES } \\
\text { EQUIPMENT SPECIFICATIONS } \\
\text { AND CHRONOLOGICAL } \\
\text { DESCRIPTION OF INSTALLATION }\end{array}$ \\
\hline $\begin{array}{l}\text { FEB, MAY, JULY. } \\
\text { SEPT, AND DEC } \\
\text { SINCE } 1 \% 9\end{array}$ & TEMPERATURE & VARIOUS LOCATIONS & UNKNOWN & $\begin{array}{l}\text { NONE PRESENKD. } \\
\text { REASONS CITED IN } \\
\text { REFERENCE 1, SEC } 3.4\end{array}$ & $\begin{array}{l}\text { WILLIAM CLAPP } \\
\text { LABS }\end{array}$ & LITHE DISCUSSION \\
\hline 1974 & TEMPERANRE & $\begin{array}{l}\text { NEAR MILLSTONE } \\
\text { POINT }\end{array}$ & MONTHLY & $\begin{array}{l}\text { NONE PRESENTED, } \\
\text { REASONS CITED IN } \\
\text { REFERENCE 1, SEC } \mathbf{3 . 4}\end{array}$ & $\begin{array}{l}\text { RESEARCH } \\
\text { CORPORATION } \\
\text { OF NEW ENGLAND } \\
\text { ( TRC) }\end{array}$ & IITHE DISCUSSION \\
\hline
\end{tabular}


Mijoy Dock, and White Point would display any observable temperature increases due to plant operation, because of the variability of shoreline temperatures from solar insolation. The effect of solar insolation on observed temperatures in Niantic Bay and Jordan Cove are cited in the Results section of the first VAST Inc. Survey (June 14-20, 1971) presented in Millstone Point Company (1972). The only monitoring station that provides both preoperational and operational temperature data on a regular basis is at Millstone Point Cove. The temperatures for this station are given in bar graph form as weekly values. In this format the temperatures are not suitably amenable to analysis. Therefore, the data were not considered in this review.

Other temperature information is available from several survey monitoring programs. However, these programs had the following shortcommings:

- Sampling. stations for the several programs were not at common locations.

- Sampl ing occured for short durations at irregular intervals.

- Data from several of the stations were not available for an entire tidal cycle.

- $\quad$ o preoperational data existed for any of the stations.

- Only a relatively few sampling periods are represented.

For the above reasons, none of the sampling programs could be used for statistical examination of the thermal alteration of preoperational conditions.

The only valid uses of data gathered in the hydrological monitoring programs are for computer model input and verification. Nearly all models employed for hydrothermal prediction are deterministic and allow comparison only with deterministic monitoring data. However, all processes, particularly those for tidal-affected waterbodies, are influenced to a considerable degree by pseudo-random parameters. The thermal plume entering tidalaffected waters may exhibit a wide variety of shapes and motions, depending 
on constantly varying ambient and discharge conditions. The possible variation in plume characteristics is pointed out in Gore, et. al. (1976b) and Dunn and Policastro (1975). In those references, the plume extent and surface areas have been noted to vary by factors of 2 and 5, respectively, for electric generating stations on the Great Lakes and for a generating station on the tidal affected portion of the Connecticut River.

Aquatic biota in the region of the plant may experience a constantly varying level of thermal exposure. The exposure level, duration and time percentage were not accurately estimable from only a few thermal surveys (provided for plume model verification) since they represent only a few of the possible plume distributions.

In addition to the considerations above, the thermal sampling was not designed to augment the aquatic ecological monitoring performed at Millstone Nuclear Power Plant.

For these reasons, the thermal and dye surveys do not support any analyses attempting to quantify the thermal impact of the discharge on aquatic biota.

\section{MODHS}

The modeling of the Millstone discharge, intake and surrounding waters took two forms. The first attempted to determine the extent and shape of the thermal plume. The second attempted to generate a typical flowfield tidal sequence near the plant to be used in a model of the long-term effects of plant operation on winter flounder.

The models employed for prediction of the thermal plume had the following characteristics [c.f. Northeast Utilities Company (1975)]:

- Steady state conditions.

- Uniform ambient current.

- $\quad$ o wind effects.

- $\quad$ ombient stratification.

- N vertical or longitudinal diffusion for the far field model.

- Lateral eddy diffusion coefficient proportional to the $4 / 3$ order of the plume width. 
These characteristics are adopted by the near-field Stolzenback and Harl eman (1971) model for surface discharges and are employed for calculations of the far-field dilution according to Harleman (1972). A recent review, Dunn and Policastro (1975), of state-of-the-art surface discharge models does not recommend the use of the Stolzenback and Harleman surface discharge model based on a comparison of predictions (for numerous models) and field data. A valid analysis of this model's success in predicting the plume characteristics for the Millstone discharge is not possible. The only thermal monitoring survey (there were only two) which was able to isolate the thermal plume from the background thermal structure (VAST, Inc., MarchApril 1972) was used to both calibrate and verify the plume predictions. The results of this calibration-verification are shown in Figure 4. Model computational parameters (probably entrainment or eddy diffusion coefficients) were adjusted until reasonable agreement was obtained between prediction and field data.

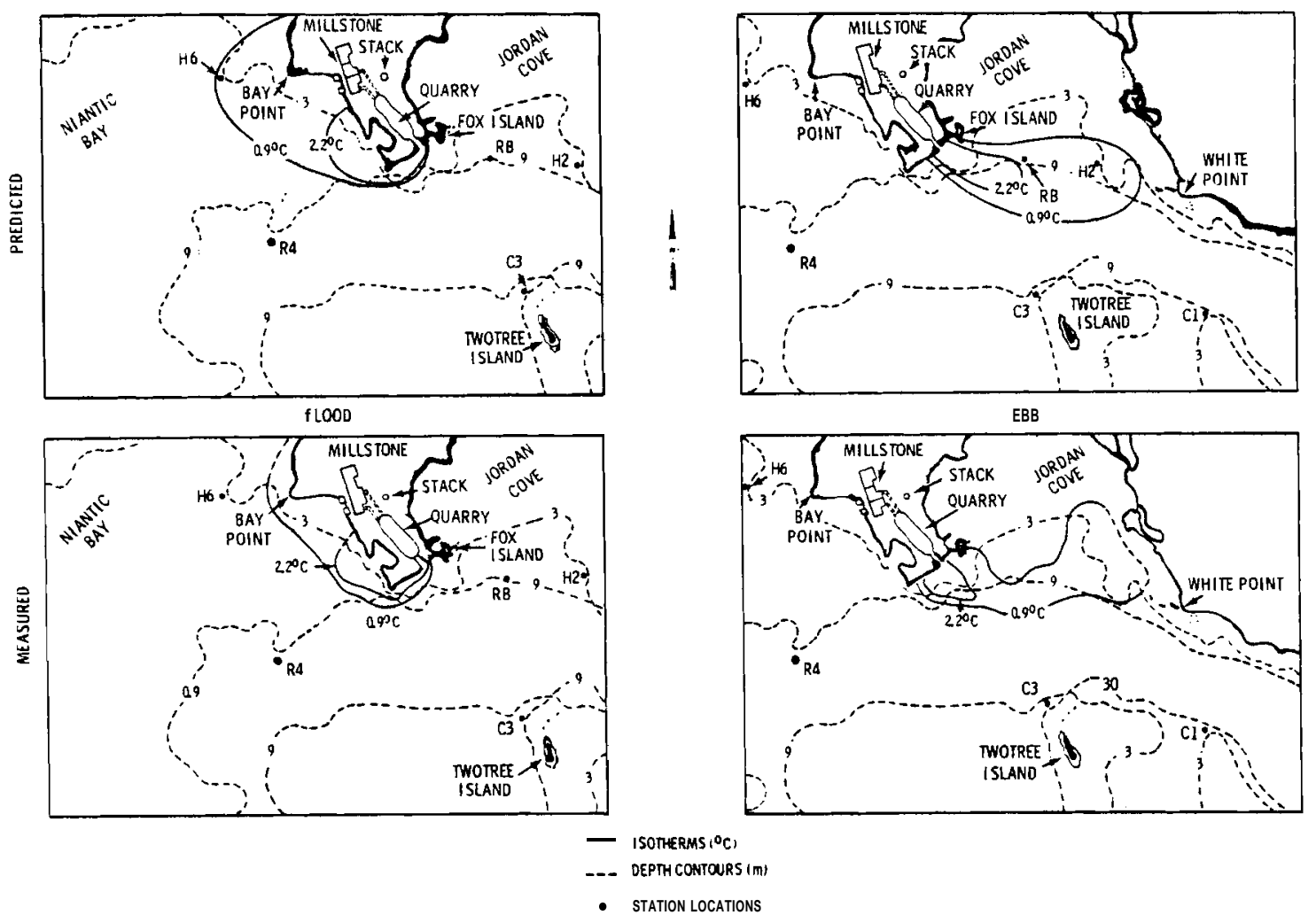

FGURE 4. Predicted vs Measured Thermal

Patterns (from March 1972 SurveyUnit 1) 
The second modeling effort utilized the two-dimensional long wave model developed by Leenderste (1967). This model calculated the flow field in the tidally influenced region as a function of time. It was one of the more sophisticated tools available for flow field prediction when the winter flounder study began. The code has demostrated its potential for accurate prediction of tidal flow fields, provided that accurate knowledge of flow conditions at boundaries are available. It also requires reasonable verification data in order that bottom friction can be estimated. Additional required input includes: boundary geometry, bathymetry, latitude of the area, river and power plant discharge and intake flow rates, and wind and atmospheric pressure data. In addition to the two-dimensional assumptions on flow field characteristics, the model also assumes that the water body is homogeneous horizontally and that lateral eddy viscosity is negligible compared to the vertical momentum flux. The latter can be treated as a bottom shear stress in the two-dimensional momentum equations. The equations employed in the model include accelerative terms as well as Coriolis forces.

The region around Millstone Nuclear Power Station that was segmented is shown in Figure 5 with the model boundaries indicated. The open boundary (the dashed line) must input the tidal height as a function of time at every node. Since Long Island Sound acts as a tidal resonator, the tidal heights and phases change as one proceeds from the Atlantic to New York Harbor (tidal height changes from about $0.7 \mathrm{~m}$ at Mystic River, Connecticut to $2.2 \mathrm{~m}$ at Port Chester, New York). For the model area, the change in tidal height was determined to be $0.05 \mathrm{~m}$ with a standard deviation of $0.04 \mathrm{~m}$ (from tidelevel monitoring performed in 1973 and 1974). The phase lag in tides for the western end of the model was estimated to be 11.1 min with a standard deviation of 18.2 min (Northeast Utilities, 1975). The inclusion of even these slight changes in boundary conditions improved the predictions dramatically.

The model used tide level information obtained from hydrological monitoring to obtain a flow field prediction, and then velocity data from current meter monitoring for comparison and calibration. The bottom roughness (or Manning's coefficient) equalled one of three values $(0.02,0.03$, or 0.045$)$ 


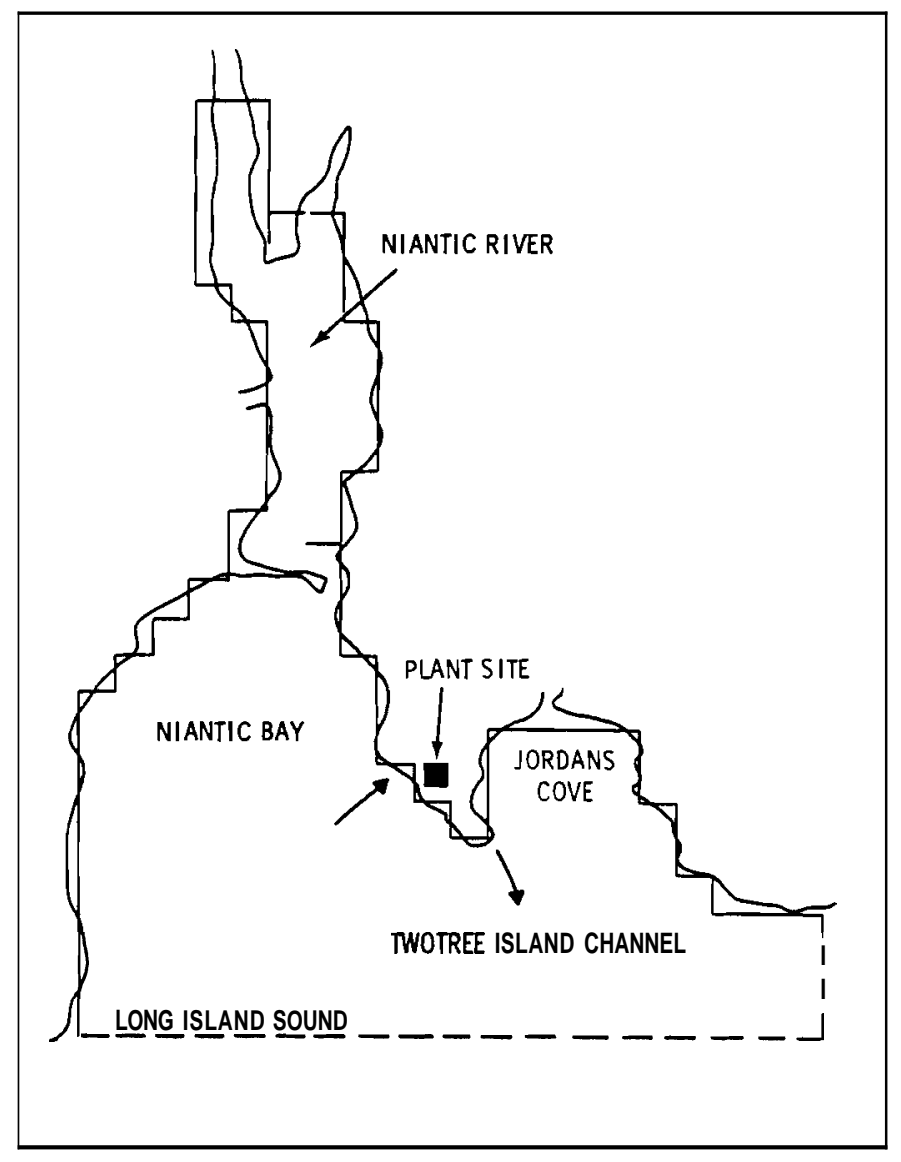

FIGURE 5. Tidal Circulation Model

depending on the bathymetric conditions and the velocity profiles obtained. The tidal wave amplitudes used in the model region varied from $0.41 \mathrm{~m}$ on the east boundary to $0.44 \mathrm{~m}$ in the southwest corner. A phase lag of $10.5 \mathrm{~min}$ was used across the model region (east to west). With these inputs and refinements, the code predicted the flow field and tidal heights within the model region. A comparison of the predicted flow field velocities at points where current meter measurements were available is shown in Figure 6. Reasonably good agreement between current direction and magnitude existed between predicted and observed data. It is interesting to note that this model was applied by two different groups at the same time (as directed by the utility) with essentially the same results. 

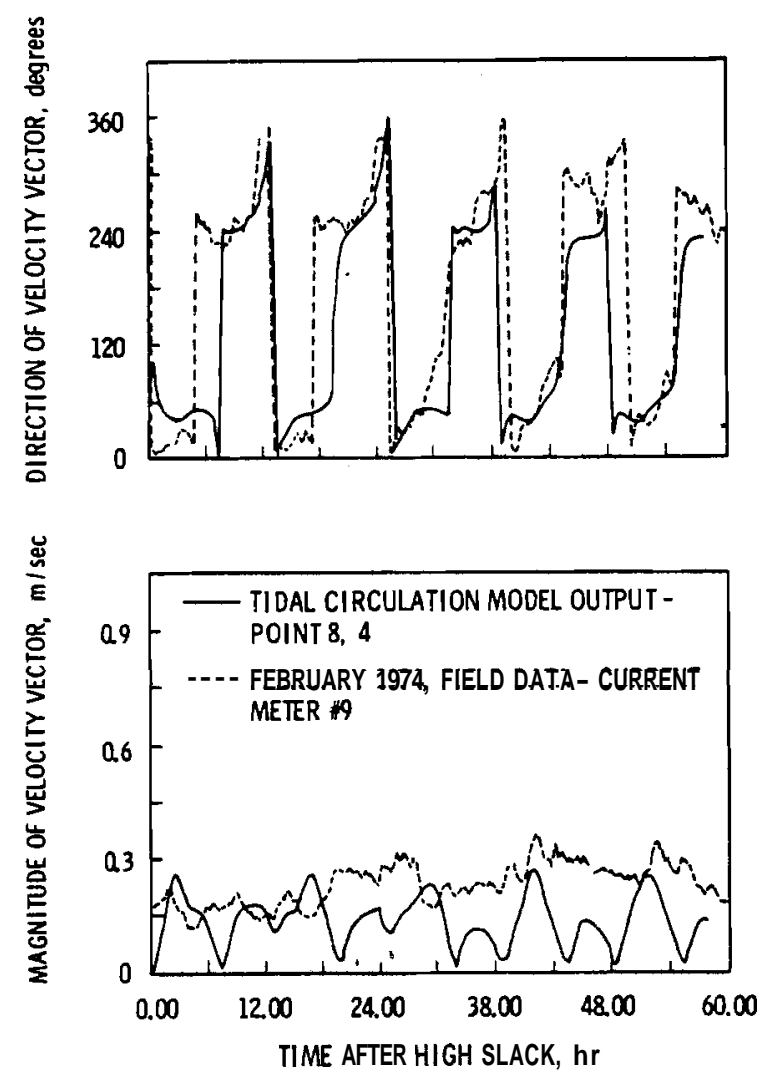

FGURE 6. Comparison of Field and Tidal Model Current Data

The data from the February, 1974, current and tidal level monitoring program were the only data used for calibration/verification of the model. The data from the August-September, 1973, current and tidal level monitoring study were found to be unacceptable for use in model calibration/verification for the following reasons [c.f. Northeast Utilities Company (1975)]:

- Data were not of high statistical quality.

- There was no $\log$ of the current meter starting times.

- The field data collected were not at the end points of the open boundaries of the tidal circulation model.

- The 10 min sampling rate was not fast enough to reduce the error in tidal lag measurements to an acceptable level. These problems were evidently corrected for the 1974 measurements. 
One other aspect of the model application is that it was necessary to use field tide level information on the model boundaries rather than the common sinusiodal tide level relation, in order to obtain acceptable agreement between field data and model predictions.

All of the above factors point to the necessity for consideration of the type of models used for hydrodynamic and hydrothermal prediction when the monitoring programs are being designed, particularly the operational and preoperational programs.

It is unfortunate that the predictions of the tidal current model obtained during examination of winter flounder was not tapped as input to a transport model for thermal advection and diffusion. Considering the number of dye diffusion studies that were carried out at the site (providing an excellent estimate of the eddy diffusion), an improved prediction of far field transport of the thermal effluents might have been possible.

The only other model employed for examination of the site was a physical model of the region performed by Alden Labs. However, little use was made of the quantitative information resulting from this model study. $\mathbf{N}$ monitoring data were compared to simulations from this model.

\section{BCOLOGICAL}

$\underline{\text { Introduction }}$

Few of the ecological monitoring programs provided temperature data which could be used to detect thermal impacts on the biota near the plant. For example, the benthic sampling stations were located in areas most likely to experience a thermal influence, but very little preoperational and operational data were presented. The reported temperatures were collected by divers quarterly.

$\underline{\text { Trawl and Ichthyopl ankton }}$

The trawl studies recorded semi-monthly water temperatures during each trawl. Although a trawl was made in the vicinity of the plant intake, no trawls occurred near the thermal discharge, nor in the areas affected by 
the thermal plume on the ebb tide. The data are not useful for determining the effect of thermal increases because it is not known where or how the data were taken during each trawl.

The ichthyoplankton study produced temperature data more suited for analysis of thermal impacts. Even so, data are only available from May 1973 to April 1974. Weekly temperature observations exist at the surface, middepth and bottom at the stations shown in Figure $7 . \quad \mathrm{N}$ preoperational temperatures were available for these stations. Data from Stations 5, 6, $8,10,11$ and 13 were selected for analysis because these stations were nearest to the plant's discharge.

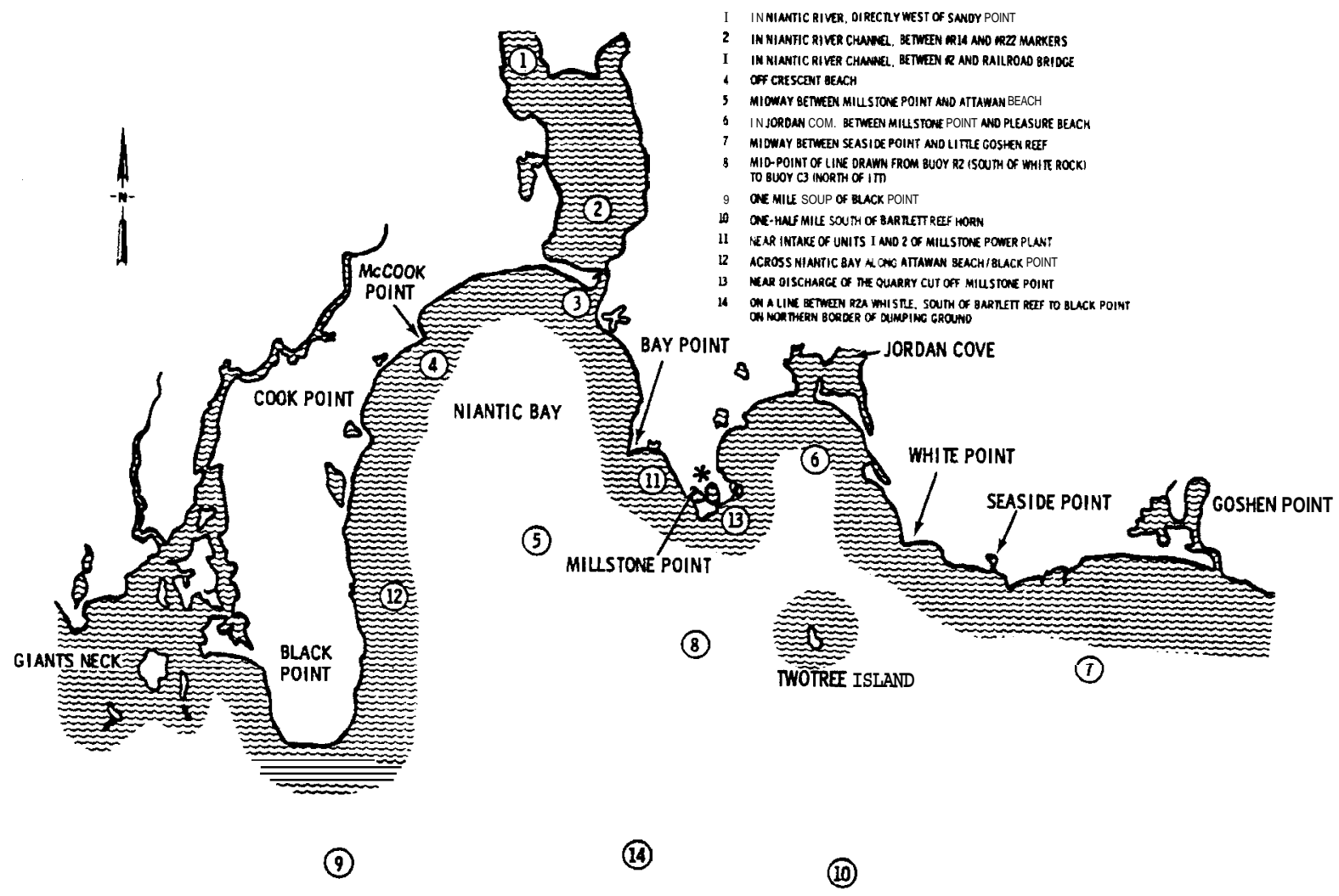

FGURE 7. Ichthyoplankton Sampling Stations 
N ichthyoplankton temperature data were presented in the reports we were able to obtain. Data were obtained from printouts of ichthyoplankton computer data cards. Values were selected from similar times of day at each station. Stations 5, 6, 8 and 10 had weekly temperatures from 1 June 1973 to mid-August 1974. Stations 11 and 13 recorded temperatures from early February 1974 to April 1974.

Figure 8 presents surface temperatures from Stations 5, 6 and 8 near Mil 1stone Point. Temperatures show a seasonal increase and decline, and from September through November, 1973, temperatures at Stations 6 and 8 appeared slightly higher than temperatures at Station 5. In addition, it appears that temperatures were slightly elevated at Station 6 compared to Station 8. These comparisons indicate that the higher temperatures observed at Station 6 were not due to chance variations in normal water temperature.

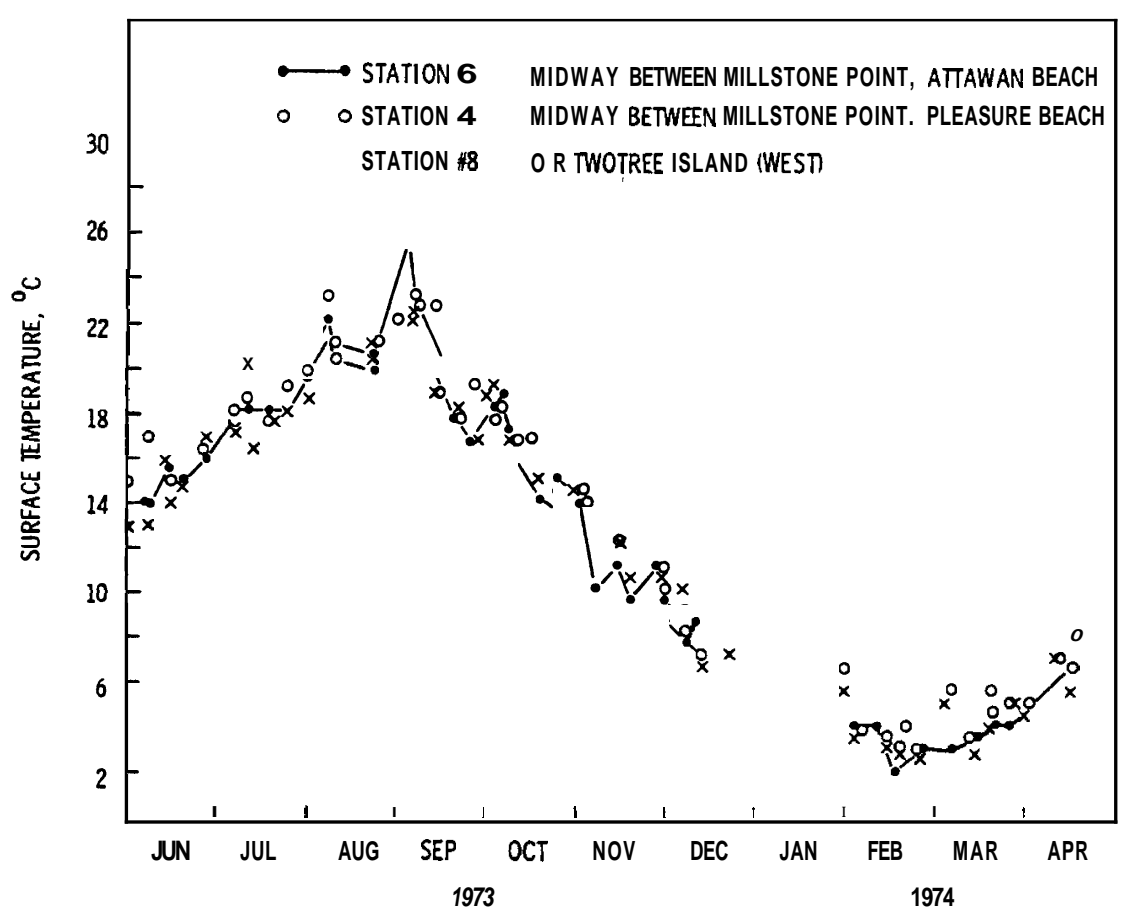

FGURE 8. Ichthyoplankton, Temperature $\left({ }^{\circ} \mathrm{C}\right)$ at Stations 5, 6 and 8 
Figure 9 presents temperatures from Station 10, one-half mile south of Bartlett Reef Horn. A comparison with the data for Station 8 in Figure 8 indicates no numerical difference. Station 10 is well out of any thermal influence from the plant and is assumed to represent thermally unaffected temperatures. Since no difference existed between Stations 8 and 10 , then we could surmise that Station 8 also received no thermal influence from the plant.

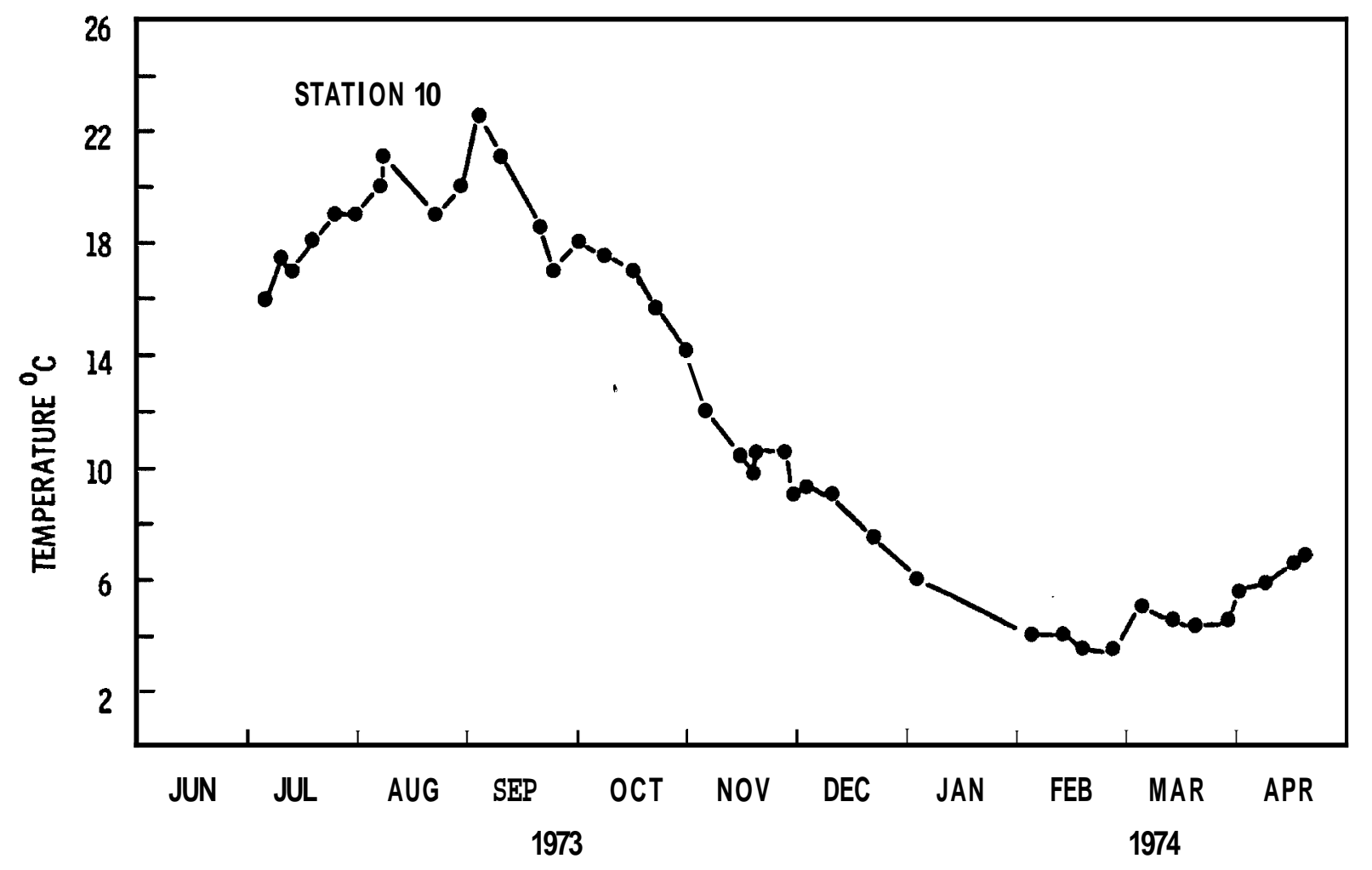

$\underline{\text { FIGUR }}{ }^{\prime}$ 9. Temperatures $\left({ }^{\circ} \mathrm{C}\right)$ at Ichthyoplankton Station 10

Ichthyoplankton - Thermal Plume

Surface regions affected by the plant's thermal discharge are depicted in Figure 4. Comparison of this figure with ichthyoplankton Stations 5, 6 and 8 in Figure 7 indicates that the plume would most likely affect Station 6. Station 6 and 8 show significant temperature differences, although only at the $a=0.05$ level. 
Some thermal impact, however small, does exist at Station 6. No adverse effects on icthyoplankton at Station 6 are cited in the Environmental or Summary Reports. Data from the other stations disclosed no significant thermal impact. The water temperatures at these stations represented ambient conditions. Thus, although the ichthyoplankton study provided no preoperational temperature data, it provided more comprehensive temperature data in the general vicinity of the thermal plume than any of the other ecological monitoring programs.

\section{Water Quality}

Temperatures were collected during a $1 \mathrm{yr}$ water quality study performed by the Travellers Research Company (TRC). Samples were collected monthly at all stations on ebb and flood tides. Stations located within the influence of the thermal plume were sampled at the surface, mid-depth and $0.3 \mathrm{~m}$ above the bottom. No direct temperature data were reported in the data available to us.

\section{SUMARY}

The nonecological monitoring programs did not provide either qualitative or quantitative analysis of thermal impact on aquatic biota. Monitoring programs were designed primarily to provide input, calibration and verification of hydrodynamic and hydrothermal models. The only monitoring results, which provided for application of the thermal plume model, were used for both calibration and verification, therefore no assessment of the model predictive capability is possible for this site.

Use of the Leendertse two-dimensional long wave model to simulate the currents in the vicinity of Millstone Power Plant was calibrated and verified with tidal gage and current meter measurements for 2 weeks in February 1974. Although reasonable quantitative agreement was obtained for tidal flows in the site vicinity, no use was made of this code relative to transport of thermal or chemical effluents.

From the examination of the limited amount of suitable data obtained from the hydrological monitoring programs for this plant, it appears that 
monitoring programs designed for the verification of model predictions do not provide good data for support of operational assessment of thermal impact on aquatic biota.

None of the ecological monitoring programs collected adequate hydrological temperature data. No program produced comparable preoperational and operational temperatures. Few actual temperatures were reported in the reports available to us. Although temperature data from the ichthyoplankton studies indicate that Station 6 experienced a small temperature increase, the data were not comparable with other ecological and nonecological temperature monitoring programs. $\mathrm{N}$ analyses of thermal impacts on the aquatic biota surrounding Millstone Point was possible from the collected temperature data because the data were collected for thermal model verifications. 
IX. ANALYSIS OF ECOLOGICAL MONITORING PROGRAMS 


\section{ANALYSIS OF BCOLOGICAL MONITORING ROCRAMS}

\section{ROCKY SHORE COMMUNIIIES}

We were unable to use percent coverage estimates from the six individual quadrats, made along each of the $30 \mathrm{~m}$ station transects, because data were reported for only 2 preoperational yr. In addition, we found no relationship between mean or individual quadrat percent coverage values and those reported for the entire respective station transect. The latter values were reported for 2 preoperational yr up to the present time but we only used data through 1973 in our analysis. However, in several reporting periods at different stations no value for percent coverage was reported. We have assumed that the measurements were not collected because we could not accept as factual the dissappearance of an entire community in one sampling period and its subsequent reappearance in the next sampling period. Examples for the barnacle Balanus balanoides at Giants Neck in 1971 and at Fox Island South in 1972 are illustrated in Table 5 where all the available data through 1973 for three algae species and two species of barnacles (a different species was found at the Bay Point station) are listed.

Because of these presumed missing values, we only made comparisons where percent coverage values were obtained at both Giants Neck (control), and one of the three stations subject to heated effluent (Bay Point and Fox Island stations). Data was not used from White Point because of the potential effects from two reported oil slicks during the preoperational period (February 1969 and May 1970). In addition, the one-to-one comparison with three heated stations and one control already emphasized any bias for the control station. We were unable to obtain information to indicate that an effort was made to "ecologically match" the control station to any of the heated locations. Apparently, the Bay Point station was subject to the heaviest surf and winds, Fox Island South was the most sheltered, while the others were intermediate. Strong surf may explain the different barnacle species observed at Bay Point. We selected four of the five species shown in Table 5 for further evaluation because they were most abundant during a majority of observation times. 
TABLE 5. Estimated Coverage (\% of Total Transect, Area Covered) 1

for Selected Flora and Fauna in the Millstone Point Area

\begin{tabular}{|c|c|c|c|c|c|c|c|c|c|c|c|c|c|c|c|c|c|}
\hline & & & GIAN & NECK & & & FOX I & LANO NORM & & & OX ISLA & D SOUTH & & & BAY & OINT & \\
\hline & $\begin{array}{l}\text { DATE PERCENTACE } \\
\text { ESTIMATED }\end{array}$ & $\begin{array}{l}\text { Ascophyllum } \\
\text { nodosum }\end{array}$ & $\frac{\text { Eucus }}{\text { SRP }}$ & $\begin{array}{l}\text { Chondrus } \\
\text { crispus }\end{array}$ & $\begin{array}{c}\text { Balanus } \\
\text { balanoides }\end{array}$ & $\frac{\text { Ascophyllum }}{\text { nodosum }}$ & $\frac{\text { Fucus }}{p}$ & $\begin{array}{l}\text { Chondrus } \\
\text { crispus }\end{array}$ & $\begin{array}{l}\text { Balanus } \\
\text { balanoides }\end{array}$ & $\begin{array}{c}\text { Ascophyllum } \\
\text { nadlosum } \\
\end{array}$ & $\begin{array}{c}\text { Eucus } \\
\text { Sp.p. }\end{array}$ & $\begin{array}{l}\text { Chondrus } \\
\text { crispus }\end{array}$ & $\begin{array}{l}\text { Balanus } \\
\text { halanoides }\end{array}$ & $\begin{array}{c}\text { Ascophyllum } \\
\text { nodosum }\end{array}$ & $\frac{\text { Eucus }}{S P R}$ & $\begin{array}{l}\text { Chondrus } \\
\text { crispus } \\
\end{array}$ & $\begin{array}{c}\text { Balanus }^{2} \\
\text { crenatus } \\
\end{array}$ \\
\hline & & & & & & & & PREOPERA & TIONALPERIC & & & & & & & & \\
\hline & $1 \% 9$ & & & & & & & & & & & & & & & & \\
\hline & $\begin{array}{l}\text { MAY } \\
\text { JUL } \\
\text { SEP } \\
\text { DEC }\end{array}$ & $\begin{array}{l}30 \\
30 \\
50 \\
60\end{array}$ & $\begin{array}{l}70 \\
70 \\
50 \\
40\end{array}$ & 55 & $\begin{array}{l}85 \\
25 \\
75 \\
65\end{array}$ & 10 & $\begin{array}{r}90 \\
100 \\
90 \\
65\end{array}$ & $\begin{array}{r}5 \\
5 \\
15\end{array}$ & $\begin{array}{l}95 \\
90 \\
a 5 \\
65\end{array}$ & $\begin{array}{l}50 \\
50 \\
40 \\
60\end{array}$ & $\begin{array}{l}50 \\
50 \\
60 \\
40\end{array}$ & & $\begin{array}{l}45 \\
60 \\
40\end{array}$ & & $\begin{array}{r}35 \\
20 \\
5 \\
25\end{array}$ & & $\begin{array}{l}75 \\
70 \\
30 \\
75\end{array}$ \\
\hline & $\underline{1970}$ & & & & & & & & & & & & & & & & \\
\hline & $\begin{array}{l}\text { FEB } \\
\text { MAY } \\
\text { JUL } \\
\text { SEP } \\
\text { OEC }\end{array}$ & $\begin{array}{l}50 \\
40 \\
30 \\
60 \\
50\end{array}$ & $\begin{array}{l}M \\
50 \\
95 \\
60 \\
40\end{array}$ & $\begin{array}{r}5 \\
20 \\
10\end{array}$ & $\begin{array}{l}50 \\
80 \\
90\end{array}$ & $\begin{array}{r}5 \\
20 \\
10\end{array}$ & $\begin{array}{l}50 \\
60 \\
90 \\
85 \\
50\end{array}$ & $\begin{array}{r}30 \\
10 \\
10 \\
5 \\
10\end{array}$ & $\begin{array}{l}70 \\
90 \\
25 \\
70 \\
.\end{array}$ & $\begin{array}{l}60 \\
40 \\
40 \\
40 \\
40\end{array}$ & $\begin{array}{l}40 \\
75 \\
60 \\
60 \\
60\end{array}$ & $\begin{array}{l}10 \\
35\end{array}$ & $\begin{array}{l}70 \\
70 \\
70 \\
65\end{array}$ & 5 & $\begin{array}{r}10 \\
10 \\
\\
5 \\
10\end{array}$ & 17 & $\begin{array}{l}75 \\
90 \\
85 \\
60\end{array}$ \\
\hline & & & & & & & & OPERATI & ONAL PERIOD & & & & & & & & \\
\hline$\stackrel{\circ}{0}$ & $\underline{1971}$ & & & & & & & & & & & & & & & & \\
\hline & FEB & 40 & 30 & 15 & 75 & & -ICE & OVERED & - & 40 & 30 & 15 & 67 & & ICE AN & SNOW & \\
\hline & $\begin{array}{l}\text { MAY } \\
\text { JUL }\end{array}$ & $\begin{array}{l}M \\
30\end{array}$ & $\begin{array}{l}20 \\
50\end{array}$ & 10 & 90 & $\begin{array}{l}40 \\
10\end{array}$ & $\begin{array}{l}40 \\
60\end{array}$ & $\begin{array}{r}10 \\
5\end{array}$ & & $\begin{array}{l}10 \\
40\end{array}$ & $\begin{array}{l}60 \\
40\end{array}$ & $\begin{array}{r}5 \\
10\end{array}$ & $\begin{array}{l}85 \\
75\end{array}$ & $\begin{array}{l}5 \\
5\end{array}$ & $\begin{array}{l}5 \\
5\end{array}$ & $\begin{array}{r}5 \\
10\end{array}$ & $\begin{array}{l}\not 20 \\
80\end{array}$ \\
\hline & SEP & M & 60 & 10 & 70 & 10 & 60 & 5 & 50 & 50 & 10 & 5 & & & & 50 & 40 \\
\hline & DEC & 40 & 40 & 5 & & $M$ & 40 & 5 & 40 & 30 & 25 & 5 & & 2 & 2 & 5 & 40 \\
\hline & 1972 & & & & & & & & & & & & & & & & \\
\hline & FEB & 40 & 30 & 5 & 75 & 10 & 50 & 1 & - & 30 & 20 & 10 & 50 & 1 & & 10 & \\
\hline & MAY & 30 & 70 & 5 & & 20 & 50 & & 85 & M & 5 & 5 & & & & 5 & 85 \\
\hline & $\begin{array}{l}\text { JUL } \\
\text { SEP }\end{array}$ & $\begin{array}{l}40 \\
40\end{array}$ & 40 & $\begin{array}{l}5 \\
5\end{array}$ & & 30 & 20 & 5 & 75 & 10 & 50 & & 80 & & & $\begin{array}{l}5 \\
3\end{array}$ & $\begin{array}{l}70 \\
35\end{array}$ \\
\hline & $\begin{array}{l}\text { SEP } \\
\text { OEC }\end{array}$ & $\begin{array}{l}40 \\
30\end{array}$ & $\begin{array}{l}60 \\
50\end{array}$ & & & $\begin{array}{l}10 \\
20\end{array}$ & $\begin{array}{l}60 \\
40\end{array}$ & $\begin{array}{l}5 \\
5\end{array}$ & & $\begin{array}{l}30 \\
30\end{array}$ & $\begin{array}{l}30 \\
30\end{array}$ & 5 & & & & $\begin{array}{l}3 \\
5\end{array}$ & $\begin{array}{l}35 \\
50\end{array}$ \\
\hline & $\underline{1973}$ & & & & & & & & & & & & & & & & \\
\hline & FEB & 35 & 40 & 5 & 50 & 20 & 50 & 1 & 50 & 30 & 25 & 5 & 40 & & & 10 & \\
\hline & MAY & 45 & 35 & 3 & 80 & 5 & 50 & $\begin{array}{l}1 \\
1\end{array}$ & 70 & 30 & 25 & 1 & 80 & 1 & & 5 & 85 \\
\hline & JUL & 60 & 40 & 1 & 75 & $\begin{array}{l}5 \\
1\end{array}$ & 50 & 1 & 40 & 30 & 20 & 1 & 75 & 1 & & 5 & 70 \\
\hline & SEP & 50 & 40 & 3 & 75 & 1 & 70 & 1 & 40 & 40 & 20 & & 60 & & & 3 & 35 \\
\hline & & 50 & 40 & 5 & 70 & 10 & 55 & 1 & 50 & M & 25 & 5 & 65 & & & 5 & 50 \\
\hline & $I_{A C C}$ & JRACY ESTIM & ED AS 1 & & & & & & & & & & & & & & \\
\hline & $6 \mathrm{SPEC}$ & IES IS Balanus & crenatu & RATHER THA & $\checkmark$ Balanus bal: & noides AT OTHE & R STATIC & & & & & & & & & & \\
\hline & ALGA & & & & & & & & & & & & & & & & \\
\hline & $\frac{A s}{C u}$ & $\begin{array}{l}\text { cophyllum nado } \\
\text { sus spp } \\
\text { ondrus crispus }\end{array}$ & & & & & & & & & & & & & & & \\
\hline & BARA & IACLE & & & & & & & & & & & & & & & \\
\hline & & $s$ balanoid & & & & & & & & & & & & & & & \\
\hline
\end{tabular}


However, in examining only these data and only percent coverage information we may have failed to detect changes for the less abundant organisms. Finally, both in a Battelle Report (1975) and others, the reported coverage estimates for each organism are to be accurate to $\pm 10 \%$. N indication as to how this was determined or what it means (i.e. standard deviation, range or etc.) was given. We presume the authors meant precision vis-a-vis accuracy. Our experience indicates that ecological measurements often have coefficients of variation of $50 \%$ and sometimes higher (up to and over 100\%). W choose to interpret the $10 \%$ accuracy value to mean the reported coverage could range to $\pm 10 \%$ (i.e. $50 \% \pm 10 \%$ ) except for coverages of $10 \%$ or less and $90 \%$ or greater.

The differences between percent coverage for the control and the three heated stations for each sampling period are in Tables 6-9. Ascophyllum nodosum coverage at Bay Point was minimal during the operational period (Table 5) and only one value was reported during preoperation, so no comparisons were justified. In contrast, complete preoperational data were available for Fox Island South but the yearly average of station differences (evaluated in conjunction with their standard deviations, Table 6) show no concl usive change, even though it appears the Ascophyll um coverage decl ined relative to Giants Neck in 1973. Apparently coverage at Fox Island North increased relative to Giants Neck during the 1971 and 1972 operational years but returned to the 1970 average preoperational difference values during 1973 (if the average of three sampling periods during 1970 accurately estimates the true preoperational status). However, the 1970 average estimate itself is questionable because two sampling periods were not represented.

Differences between control and heated station coverage for barnacles are in Table 7. Because of limited data in 1971 and 1972 we cannot attribute the apparent decrease in mean coverage at Fox Island North relative to Giants Neck in 1973 over that exhibited during the preoperational years to Millstone operations. The two other stations differed by about $20 \%$ during one of the 2 preoperational years (1969 and 1970). Thus, changes at least this large in the operational years would be necessary in order to reach any conclusion. 
TABLE 6. Differences Between Coverage (\%of Total Transect Area Covered) for the Algal Ascophyllum nodosum at Control and Heated Stations'

\begin{tabular}{|c|c|c|c|}
\hline $\begin{array}{l}\text { MONTH PERCENTAGE } \\
\text { ESTIMATED } \\
\end{array}$ & $\begin{array}{l}\text { GIANTS NECK (-) } \\
\text { FOX I SLAND NORM } \\
\end{array}$ & $\begin{array}{l}\text { GIANTS NECK (-) } \\
\text { FOX ISLAND SOUTH }\end{array}$ & \multirow[t]{2}{*}{$\begin{array}{l}\text { GIANTS NECK } \\
\text { BAY POINT }\end{array}$} \\
\hline \multirow{2}{*}{\multicolumn{4}{|c|}{ PREOPERATIONAL PERIOD }} \\
\hline & & & \\
\hline $\begin{array}{l}\text { MAY } \\
\text { JUL } \\
\text { SEP } \\
\text { DEC } \\
\text { MEAN } \pm \text { SD } \\
1970\end{array}$ & $\begin{array}{c}20 \\
- \\
- \\
- \\
\end{array}$ & $\begin{array}{r}-20 \\
-20 \\
+10 \\
0 \\
-7.5 \pm 15.0\end{array}$ & $\frac{-}{-}$ \\
\hline $\begin{array}{l}\text { FEB } \\
\text { MAY } \\
\text { JUL } \\
\text { SEP } \\
\text { DEC } \\
\text { MEAN } \pm \text { SD }\end{array}$ & $\begin{array}{c}- \\
25 \\
40 \\
40 \\
35 \pm 8.7\end{array}$ & $\begin{array}{r}-10 \\
0 \\
-10 \\
20 \\
10 \\
2 \pm 13\end{array}$ & $\begin{array}{r}- \\
- \\
- \\
45 \\
-\end{array}$ \\
\hline \multicolumn{4}{|c|}{ OPERATIONAL PERIOD } \\
\hline 1971 & & & \\
\hline $\begin{array}{l}\text { FEB } \\
\text { MAY } \\
\text { JUL } \\
\text { SEP } \\
\text { DEC } \\
\text { MEAN } \pm \text { SD } \\
1972 \\
\end{array}$ & $\begin{array}{c}-\overline{10} \\
20 \\
23 \\
10 \\
10 \pm 14.1\end{array}$ & $\begin{array}{r}0 \\
20 \\
-10 \\
-20 \\
10 \\
0 \pm 15.8\end{array}$ & $\begin{array}{c}- \\
25 \\
25 \\
- \\
38 \\
29.3 \pm 7.5\end{array}$ \\
\hline $\begin{array}{l}\text { FEB } \\
\text { MAY } \\
\text { JUL } \\
\text { SEP } \\
\text { DEC } \\
\text { MEAN } \pm \text { SD } \\
1973\end{array}$ & $\begin{array}{c}30 \\
10 \\
10 \\
30 \\
10 \\
18 \pm 10.9\end{array}$ & $\begin{array}{c}10 \\
- \\
30 \\
10 \\
0 \\
10 \pm 123\end{array}$ & $\begin{array}{l}39 \\
- \\
- \\
- \\
-\end{array}$ \\
\hline $\begin{array}{l}\text { FEB } \\
\text { MAY } \\
\text { JUL } \\
\text { SEP } \\
\text { DEC } \\
\text { MEAN } \pm \text { SD }\end{array}$ & $\begin{array}{c}15 \\
40 \\
55 \\
49 \\
49 \\
39.8 \pm 15.3\end{array}$ & $\begin{array}{c}5 \\
15 \\
30 \\
10 \\
20 \\
15 \pm 9.6\end{array}$ & $\begin{array}{r}44 \\
59 \\
- \\
51.5\end{array}$ \\
\hline
\end{tabular}


TABLE 7. Differences Between Coverage (\%of Total Transect Area Covered) for the Barnacle Bal anus balanoides at Control and Heated Stations

\begin{tabular}{|c|c|c|c|}
\hline $\begin{array}{c}\text { MONTH PERCENTAGE } \\
\text { ESTIMATED }\end{array}$ & $\begin{array}{l}\text { GIANTS NECK }(-) \\
\text { FOX I SLAND NORM } \\
\end{array}$ & $\begin{array}{l}\text { GIANTS NECK }(-) \\
\text { FOX ISLAND SOUM } \\
\end{array}$ & \multirow[t]{2}{*}{$\begin{array}{l}\text { GIANTS NECK }(-) \\
\text { BAY POINT } \\
\end{array}$} \\
\hline \multicolumn{3}{|c|}{ PREOPERATIONAL PERIOD } & \\
\hline \multicolumn{4}{|l|}{$\underline{109}$} \\
\hline $\begin{array}{l}\text { MAY } \\
\text { JUL } \\
\text { SEP } \\
\text { DEC } \\
\text { MEAN } \pm \text { SD } \\
\underline{1970}\end{array}$ & $\begin{array}{c}-10 \\
-5 \\
-10 \\
0 \\
-6.3 \pm 4.8\end{array}$ & $\begin{array}{c}- \\
40 \\
15 \\
25 \\
26.7 \pm 126\end{array}$ & $\begin{array}{r}10 \\
15 \\
45 \\
-10 \\
15.0 \pm 22.7\end{array}$ \\
\hline $\begin{array}{l}\text { FEB } \\
\text { MAY } \\
\text { JUL } \\
\text { SEP } \\
\text { DEC } \\
\text { MEAN } \pm \text { SD }\end{array}$ & $\begin{array}{c}- \\
-40 \\
-5 \\
20 \\
- \\
-8.3 \pm 30.1\end{array}$ & $\begin{array}{c}- \\
-20 \\
10 \\
25 \\
- \\
5.0 \pm 229\end{array}$ & $\begin{array}{c}- \\
-40 \\
-5 \\
30 \\
- \\
-5.0 \pm 35.0\end{array}$ \\
\hline \multicolumn{4}{|c|}{ OPERATIONAL PERIOD } \\
\hline
\end{tabular}

\section{$\underline{1971}$}

FEB

MAY

JUL

SEP

DEC

MEAN $\pm S D$

$\underline{1972}$

FEB

MAY

JUL

SEP

DEC

$M E A N \pm S D$

$\underline{1973}$

FEB

MAY

JUL

SEP

DEC

$M E A N \pm S D$
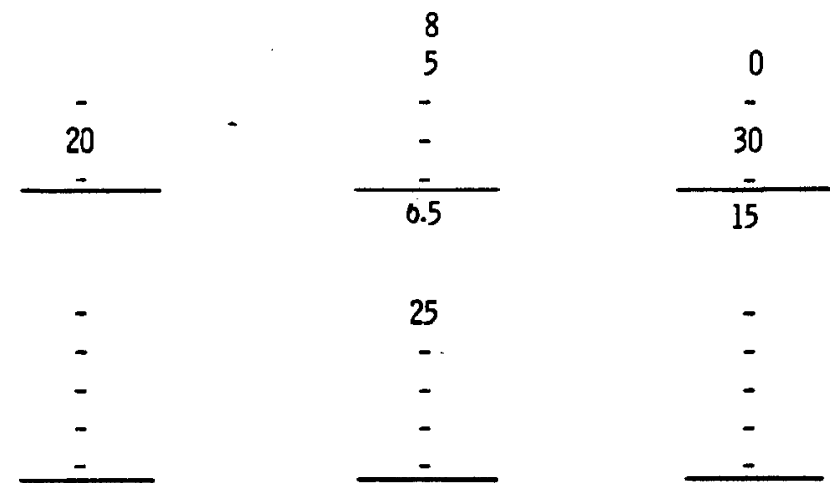

\section{ACTUALLY Balanus creantus AT BAY POINT}


TABLE 8. Differences Between Coverage (\%of Total Transect Area Covered) for the Algae Fucus spp at Control and Heated Stations

\begin{tabular}{cccc}
$\begin{array}{c}\text { MONTH PERCENTAGE } \\
\text { ESTIMATED }\end{array}$ & $\begin{array}{c}\text { GIANTS NECK (-) } \\
\text { FOX ISLAND NORM }\end{array}$ & $\begin{array}{c}\text { GIANTS NECK (-) } \\
\text { FOX ISLAND SOUTH }\end{array}$ & GIANTS NECK (-) \\
& PREOPERATIONAL PER IOD & - BAY POINT \\
\hline
\end{tabular}

$\underline{1969}$

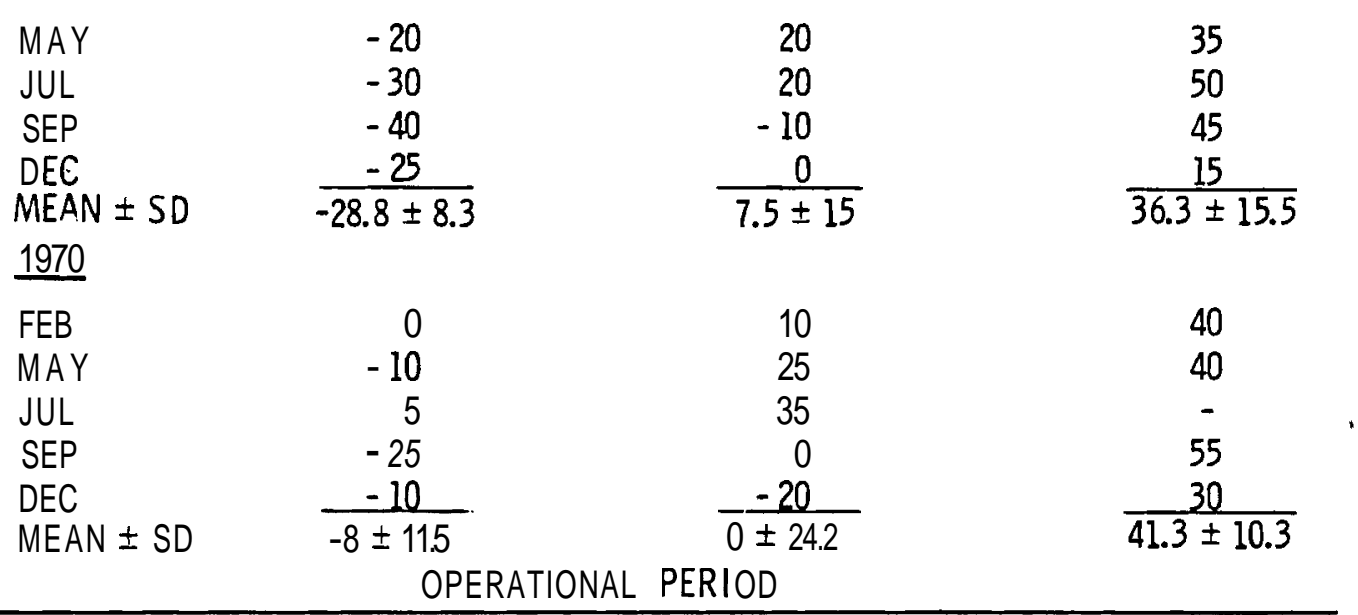

$\underline{1971}$

FEB

MAY

JUL

SEP

DEC

$M E A N \pm S D$

$\underline{1972}$

$\begin{array}{lr}\text { FEB } & -20 \\ \text { MAY } & 20 \\ \text { JUL } & 20 \\ \text { SEP } & 0 \\ \text { DEC } & 10 \\ \text { MEAN } \pm \text { SD } & 6 \pm 16.7\end{array}$
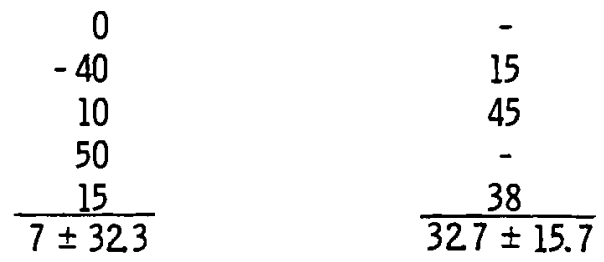

$\underline{1973}$

FEB

MAY

JUL

SEP

DEC

$M E A N \pm S D$
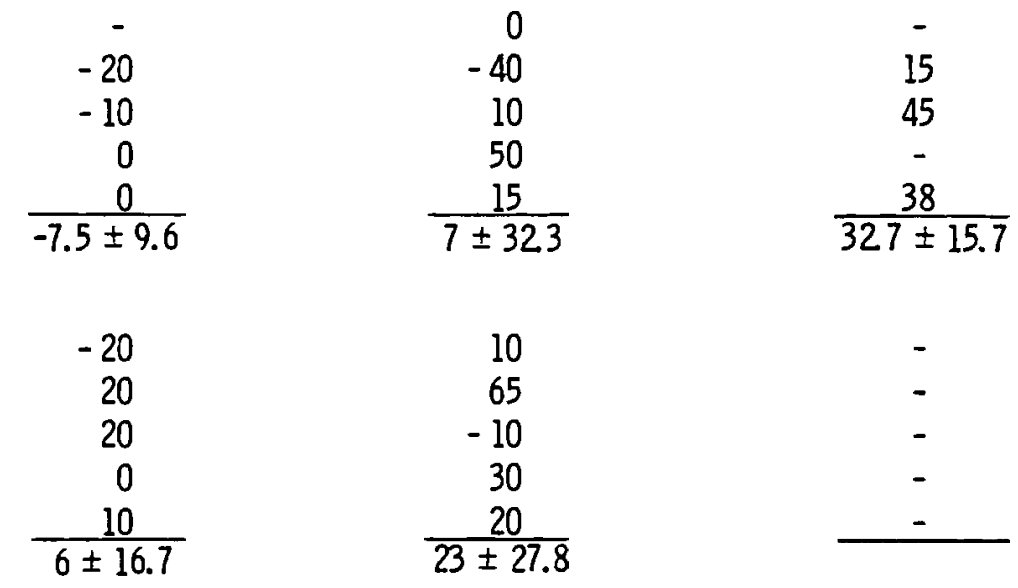

促

P

$$
-10
$$$$
-15
$$$$
-10
$$$$
-30
$$$$
-15
$$$$
\frac{-15}{+16 \pm 8.2}
$$
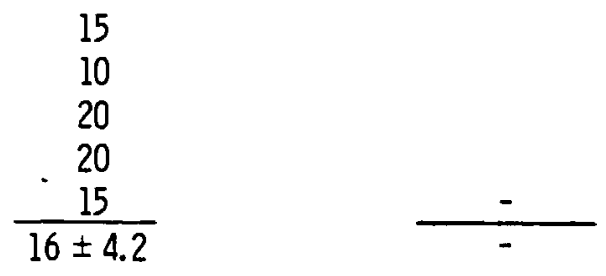
TABLE 9. Differences Between Coveraqe (\% of Total Transect Area Covered) for the Algal Chondrus crispus at Control and Heated Stations

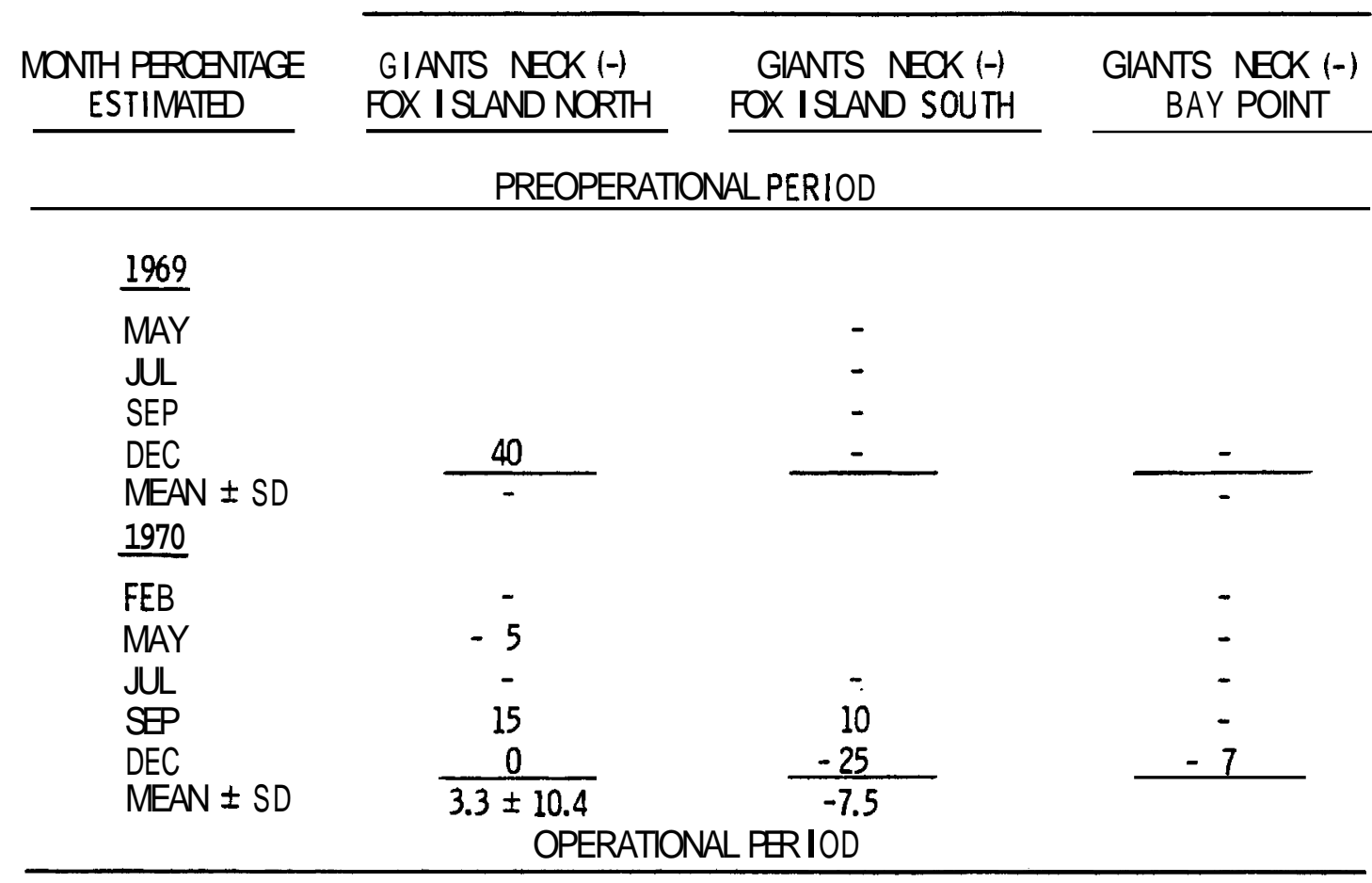

$\underline{1971}$

FEB

MAY

JUL

$\mathrm{SP}$

DEC

MEAN \pm SD

1972

FEB

MAY

JUL

SPP

DEC

MEAN $\pm S D$

1973

田

MAY

JUL

$\mathrm{SP}$

DEC

$M E A N \pm S D$
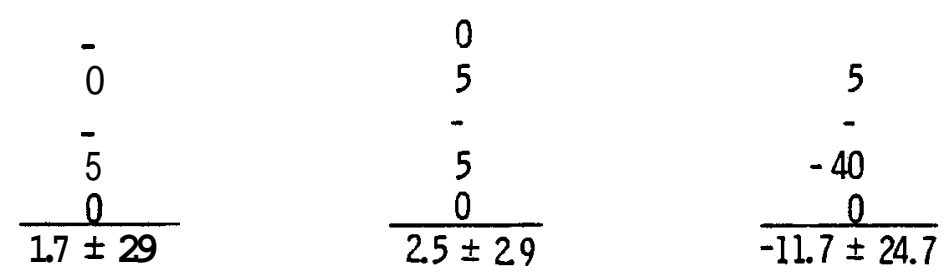

$-5$

0

$-5$

0

0

$13 \pm 23$

$-\overline{-L 7 \pm 29}$

0

0

2
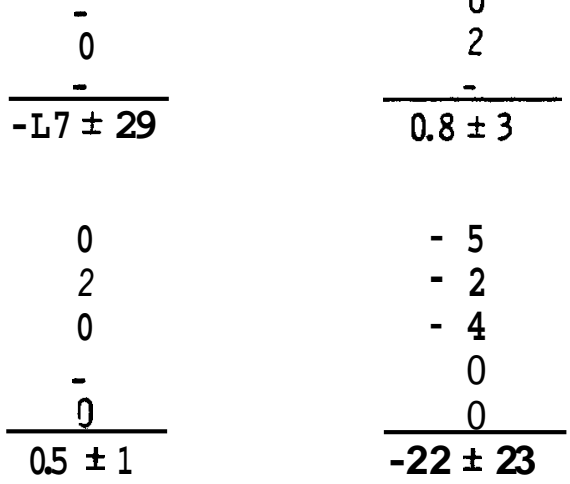
The station differences for the algae Fucus species are in Table 8. Fox Island North station coverage remained nearly constant relative to Giants Neck coverage values over the $5 \mathrm{yr}$ period (1972 might be an exception) studied, even though percent coverage apparently declined at both stations (see Table 5 and compare data from 1969 with 1973). A similar diminuation is evident for coverage at Fox Island South (Table 5) but, again, the nearly concomitant change at Giants Neck resulted in almost constant station differences. Few data were available from the operational period at Bay Point so comparisons were not made. However, if the unreported coverage values really were nearly zero, and not missing as shown, then a reduction in coverage similar to all the other stations probably occurred. Overall, it appears that coverage by Fucus species declined over the study period irrespective of the status of the Millstone Plant. The availability of data from a second control station would be of substantial aid in validating such an assertion.

The difficulties in quantitatively/qualitatively evaluating coverage for a less abundant algal species Chondrus crispus is evident from Table 9. Few preoperational data were available and mean differences tended toward zero because observed coverages were often between 0 and 10\% (Table 5). Thus, quantitative analysis of "estimated coverage" for less abundant flora or fauna may be impossible under the best conditions of measurement and frequency of observation.

\section{$\underline{\text { Summary }}$}

We did not statistically assess the percent coverage data for significant changes for three algal species and barnacles because of the reported measurement error and at times, limited data. However, a qualitative examination of the coverage results indicate that both Ascopyllum nodosum and Balanus balanoides showed changes which were difficult to interpret in terms of the operational/preoperational status of M11stone. Coverage by Fucus species declined at all stations. We questioned the usefulness of coverage measurements for less abundant species in assessing change, but believe the 
measurements for more abundant species should be quantitative where possible, rather than estimated, ifstatistically reliable estimates of change are desired (in addition to good experimental or survey design with adequate replication).

\section{BARNACLE STUDY}

The data obtained at the five sampling stations are in Table 10 and the average difference in adult barnacle diameters (mm) for the control (Giants Neck) and three heated stations are in Figures 10-12. We did not examine the size difference for barnacles from Giants Neck and Bay Point because the two species were different.

TABLE 10. Average Base Diameters $(\mathrm{mm})$ for Adult Barnacles taken at the Millstone Point Area ${ }^{1}$

\begin{tabular}{|c|c|c|c|c|c|}
\hline \multirow[b]{2}{*}{ DATE CAUGHT } & \multicolumn{4}{|c|}{ STATIONS } & \multirow[b]{2}{*}{ BAY POINT } \\
\hline & GIANTS NECK & WHIIE POINT & $\begin{array}{c}\text { FOX ISLAND } \\
\text { NORTH }\end{array}$ & $\begin{array}{c}\text { FOX ISLAND } \\
\text { SOUTH }\end{array}$ & \\
\hline \multicolumn{6}{|c|}{ PREOPERATIONAL PERIOD } \\
\hline $1 \% 9$ & & & & & \\
\hline $\begin{array}{l}\text { MAY } \\
\text { JUL } \\
\text { SEP } \\
\text { DEC }\end{array}$ & $\begin{array}{l}6.6 \\
7.9 \\
7.9 \\
7.7\end{array}$ & $\begin{array}{l}6.3 \\
8.0 \\
6.9 \\
7.6\end{array}$ & $\begin{array}{l}6.5 \\
6.7 \\
8.2 \\
7.5\end{array}$ & $\begin{array}{l}5.2 \\
6.6 \\
7.1 \\
7.1\end{array}$ & $\begin{array}{l}3.5 \\
6.4 \\
7.6 \\
7.6\end{array}$ \\
\hline \multicolumn{6}{|l|}{1970} \\
\hline $\begin{array}{l}\text { FEB } \\
\text { MAY } \\
\text { JUL } \\
\text { SEP } \\
\text { DEC }\end{array}$ & $\begin{array}{l}8.2 \\
5.9 \\
8.1 \\
9.2 \\
8.4\end{array}$ & $\begin{array}{l}8.0 \\
6.2 \\
8.0 \\
8.7 \\
8.4\end{array}$ & $\begin{array}{l}7.8 \\
5.7 \\
7.5 \\
8.6 \\
8.0\end{array}$ & $\begin{array}{l}7.3 \\
5.6 \\
6.8 \\
7.6 \\
7.5\end{array}$ & $\begin{array}{l}9.1 \\
4.6 \\
7.7 \\
9.0 \\
9.6\end{array}$ \\
\hline \multicolumn{6}{|c|}{ OPERATIONAL PERIOD } \\
\hline$\underline{1971}$ & & & & & \\
\hline $\begin{array}{l}\text { FEB } \\
\text { MAY } \\
\text { JUL } \\
\text { SEP } \\
\text { DEC }\end{array}$ & $\begin{array}{l}7.7 \\
7.9 \\
8.1 \\
8.6 \\
8.7\end{array}$ & $\begin{array}{l}7.7 \\
7.9 \\
8.4 \\
9.1 \\
9.1\end{array}$ & $\begin{array}{l}7.6 \\
7.9 \\
8.8 \\
8.7 \\
9.0\end{array}$ & $\begin{array}{l}6.3 \\
7.3 \\
7.3 \\
8.3 \\
8.8\end{array}$ & $\begin{array}{r}8.7 \\
8.2 \\
11.0 \\
9.6 \\
10.1\end{array}$ \\
\hline \multicolumn{6}{|l|}{1972} \\
\hline $\begin{array}{l}\text { FEB } \\
\text { MAY } \\
\text { JUL } \\
\text { SEP } \\
\text { DEC }\end{array}$ & $\begin{array}{l}8.8 \\
7.7 \\
8.4 \\
9.3 \\
8.4\end{array}$ & $\begin{array}{l}8.0 \\
7.9 \\
8.8 \\
9.2 \\
8.9\end{array}$ & $\begin{array}{l}7.7 \\
7.6 \\
82 \\
8.6 \\
8.1\end{array}$ & $\begin{array}{l}7.9 \\
7.5 \\
83 \\
8.1 \\
7.7\end{array}$ & $\begin{array}{r}8.8 \\
8.6 \\
8.7 \\
10.3 \\
9.9\end{array}$ \\
\hline
\end{tabular}

1 EACH ENTRY REPRESENTS M E MEAN OF SIX QUAORATS. THIRTY RANDOMLY CHOSEN BARNACLES WERE MEASURED IN EACH QUADRAT 


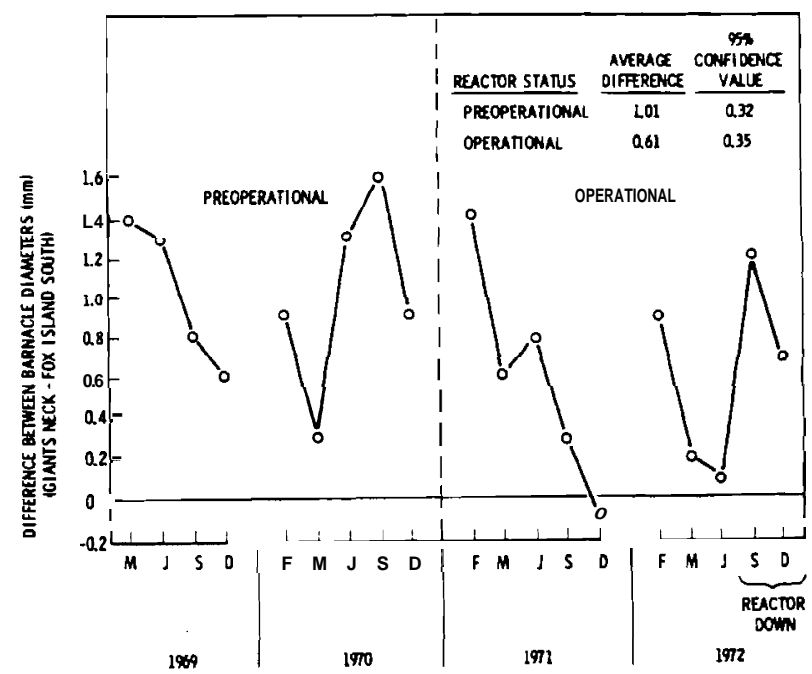

FIGURE 10. Difference Between Adult Barnacle Diameters (mm) at Giants Neck and Fox Island South

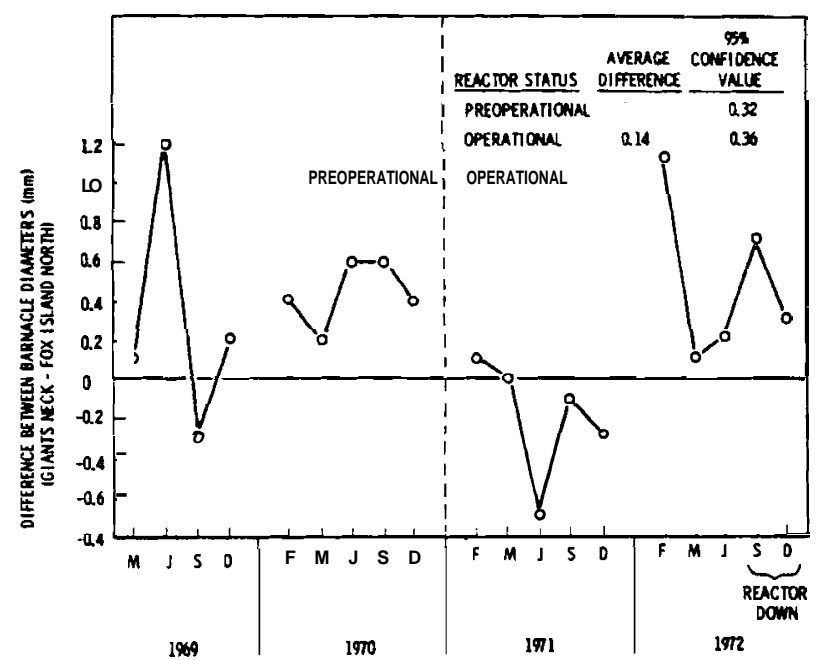

FIGURE 11. Difference Between Adult Barnacle Diameters (mm) at Giants Neck and Fox Island North 


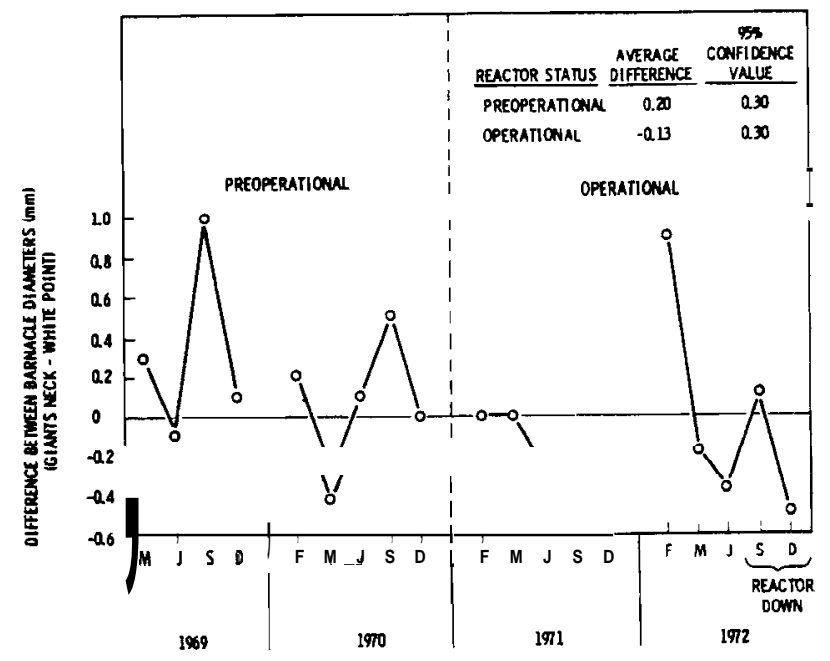

FGURE 12. Difference Between Adult Barnacle Diameters (mm) at Giants Neck and White Point

It appears that average barnacle diameters were larger at Giants Neck (Figures 10-12) than at all three heated stations during the preoperational period (no exceptions at Fox Island South, one at Fox Island North and two at White Point). Confidence limits (see the figure legends for the appropriate value to add or subtract from the means) for the preoperational data support this statement for the two Fox Island stations because zero differences are not in the interval (hopefully by using station barnacle diameter differences in our evaluation some of the serial correlation in the data were removed). Moreover, when the reactor became operational all three average diameter differences were closer to zero, indicating diameters at the heated stations approached those of the control animals at Giants Neck. In fact, average barnacle diameters increased each year at Giants Neck $7.5 \pm 1.6,8.0 \pm 0.6,8.2 \pm 0.6$, (mean \pm standard deviation) so that more than just proportional diameter increases took place at the other stations. 


\section{Summary}

N evidence for changes in barnacle diameters due to the operation of Millstone were found. Moreover, the data suggest that stations subjected to the effluent may have barnacles with diameters averages larger than expected during plant operation. However, this observation cannot be statistically supported.

\section{INTERTIDAL SAND INFAUNA}

The data collected at two nearly similar stations are in Table 11 where both total organisms counted and numbers of the principal organism (gem clam, Gemma gemma) are listed. It appears from both counts at each station and station count differences that 1969 was not a representative year, especially during December. We have plotted the differences between the control (Giants Neck) and heated station (Jordan Cove) for total organisms in Figure 13 and the gem clam in Figure 14. Even though we have included the very low values from 1969 in the calculation of preoperational average differences (1egend of each figure), it appears that the two stations were "more alike" during operational periods since these means were closer to zero. The reason (at least insofar as a comparison to 1970 data is concerned) was decreased total counts at Giants Neck (means and standard deviations were $2165 \pm 596,878 \pm 363$ and $1176 \pm 789$ for 1970, 1971 and 1972, respectively) while total counts were nearly constant a Jordan Cove $(1015 \pm 484,1147 \pm 746$, and $920 \pm$ 552). We have no reason to ascribe decreased counts at Giants Neck to other than normal population cycles. Since no concomitant decline in counts (relative to 1970) occurred at Jordan Cove, it is possible that Millstone heated effluents were beneficial. We could not statistically evaluate this possiblity.

Summary

Total counts of sand infauna organisms decreased at the control station during the years compared to the preoperational years. However, no such decline was observed at the heated station, so no detrimental effect due to Millstone operation could be determined. However, this could not be tested statistically. 
TABLE 11. Total Number of Intertidal Sand Organisms and Number of Gemma gemma (Organ isms $/ 3197 \mathrm{~cm}^{3}$ ) taken at the Millstone Point Areal

\begin{tabular}{|c|c|c|c|c|c|c|}
\hline \multirow[b]{3}{*}{ DATE CAUGHT } & \multicolumn{4}{|c|}{ STATION } & \multirow{2}{*}{\multicolumn{2}{|c|}{$\begin{array}{c}\text { GIANTS NECK I- } \\
\text { JORDAN COVE }\end{array}$}} \\
\hline & \multicolumn{2}{|c|}{ GIANTS NECK } & \multicolumn{2}{|c|}{ JORDAN COVE } & & \\
\hline & TOTAL & $\begin{array}{c}\text { TOTAL } \\
\text { Gemma gemma }\end{array}$ & TOTAL & $\begin{array}{c}\text { TOTAL } \\
\text { Gemma gemma }\end{array}$ & TOTAL & $\begin{array}{c}\text { TOTAL } \\
\text { Cemmagenma }\end{array}$ \\
\hline \multicolumn{7}{|c|}{ PREOPERATIONAL PERIOD } \\
\hline \multicolumn{7}{|l|}{1969} \\
\hline $\begin{array}{l}\overline{M A Y} \\
\text { JUL } \\
\text { SEP } \\
\text { DEC }\end{array}$ & $\begin{array}{r}33 \\
521 \\
245 \\
43\end{array}$ & $\begin{array}{c}229(98)^{2} \\
428(82) \\
26(96) \\
29(67)\end{array}$ & $\begin{array}{r}41 \\
180 \\
134 \\
27\end{array}$ & $\begin{array}{c}41 ;(100) \\
84(47) \\
107(80) \\
9(33)\end{array}$ & $\begin{array}{r}192 \\
341 \\
111 \\
16\end{array}$ & $\begin{array}{r}188 \\
334 \\
129 \\
20\end{array}$ \\
\hline \multicolumn{7}{|l|}{$\underline{1970}$} \\
\hline $\begin{array}{l}\text { FEB } \\
\text { MAY } \\
\text { JUL } \\
\text { SEP } \\
\text { DEC }\end{array}$ & $\begin{array}{l}1594 \\
1475 \\
2826 \\
2424 \\
2310\end{array}$ & $\begin{array}{c}1137(71) \\
690(47) \\
1180(42) \\
1345(56) \\
1447(58)\end{array}$ & $\begin{array}{r}370 \\
869 \\
1303 \\
1648 \\
886\end{array}$ & $\begin{array}{l}333(90) \\
508(58) \\
543(42) \\
902(54) \\
675(76)\end{array}$ & $\begin{array}{r}1224 \\
606 \\
1523 \\
776 \\
1624\end{array}$ & $\begin{array}{l}804 \\
182 \\
637 \\
443 \\
772\end{array}$ \\
\hline \multicolumn{7}{|c|}{ OPERATIONAL PERIOD } \\
\hline \multicolumn{7}{|l|}{1971} \\
\hline $\begin{array}{l}\text { FEB } \\
\text { MAY } \\
\text { JUL } \\
\text { SEP } \\
\text { DEC }\end{array}$ & $\begin{array}{r}1018 \\
1144 \\
870 \\
255 \\
1042\end{array}$ & $\begin{array}{l}470(44) \\
484(42) \\
441(51) \\
179(70) \\
443(43)\end{array}$ & $\begin{array}{r}817 \\
1399 \\
550 \\
626 \\
2343\end{array}$ & $\begin{array}{r}649 \text { R91 } \\
3441251 \\
183(33) \\
255(41) \\
2170(93)\end{array}$ & $\begin{array}{r}261 \\
-\quad 255 \\
320 \\
-\quad 371 \\
-1301\end{array}$ & $\begin{array}{r}179 \\
140 \\
258 \\
-\quad 77 \\
-1727\end{array}$ \\
\hline \multicolumn{7}{|l|}{1972} \\
\hline $\begin{array}{l}\text { FEB } \\
\text { MAY } \\
\text { JUL } \\
\text { SEP } \\
\text { DEC }\end{array}$ & $\begin{array}{r}957 \\
830 \\
2577 \\
840 \\
675\end{array}$ & $\begin{array}{r}540(56) \\
627(76) \\
1021481 \\
593(71) \\
675(49)\end{array}$ & $\begin{array}{r}690 \\
176 \\
1652 \\
887 \\
1197\end{array}$ & $\begin{array}{l}604(88) \\
147(84) \\
531(32) \\
383(43) \\
799(67)\end{array}$ & $\begin{array}{r}267 \\
654 \\
925 \\
-\quad 47 \\
-522\end{array}$ & $\begin{array}{r}-64 \\
\mathbf{4 8 0} \\
701 \\
210 \\
-124\end{array}$ \\
\hline \multicolumn{7}{|l|}{1073} \\
\hline $\begin{array}{l}\text { FEB } \\
\text { MAY }\end{array}$ & $\begin{array}{l}2264 \\
1287\end{array}$ & $\begin{array}{l}1146(56) \\
517(40)\end{array}$ & $\begin{array}{l}624 \\
744\end{array}$ & $\begin{array}{l}581(93) \\
665(89)\end{array}$ & $\begin{array}{r}1440 \\
543\end{array}$ & $\begin{array}{r}565 \\
-148\end{array}$ \\
\hline $\begin{array}{ll}1 & \text { EACH } \\
2 & \text { PARE }\end{array}$ & $\begin{array}{l}\text { VTRY REP } \\
\text { METIC V }\end{array}$ & $\begin{array}{l}\text { EENTS M E SUM } \\
\text { JES ARE PERCENT }\end{array}$ & $\begin{array}{l}\text { FIVE SU } \\
\text { EES OF Ge }\end{array}$ & AMPLES 1639 & ISITE & \\
\hline
\end{tabular}

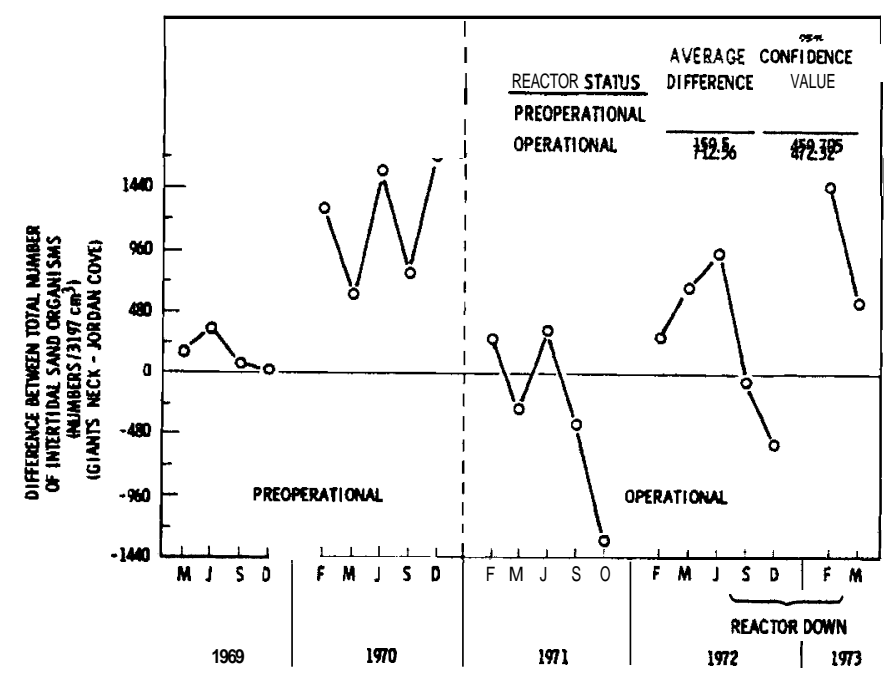

FIGURE 13. Difference Between Number of Total Intertidal Sand Organisms (Number $/ \mathrm{cm}^{3}$ ) at Giants Neck and Jordan Cove 


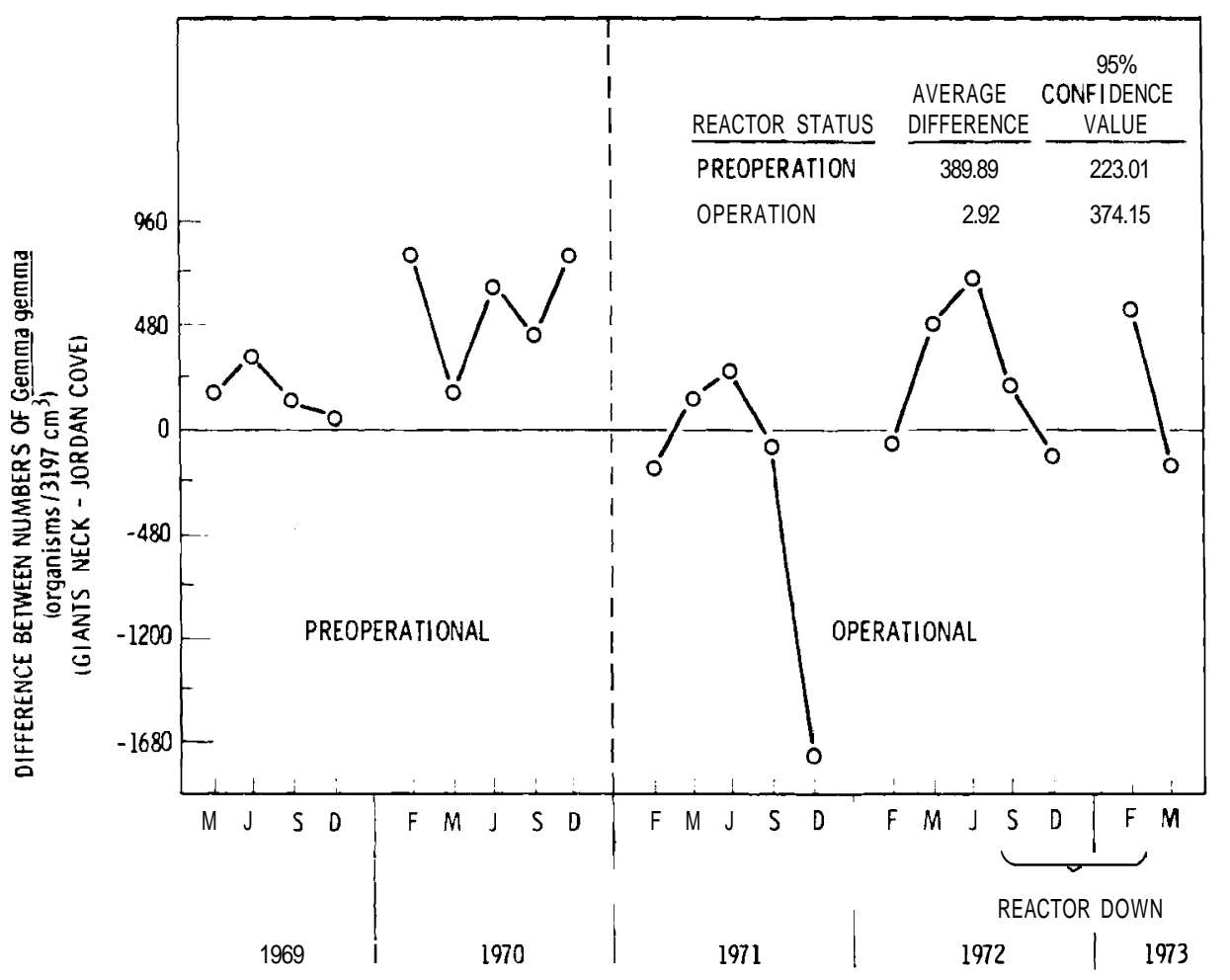

FGURE 14. Differences Between Numbers of ${ }^{3}$ Gemma gemma (Organisms/3197 $\mathrm{cm}^{3}$ ) at Giants Neck and Jordan Cove

\section{OYSIER GROWTH STUDY}

The data for both average oyster length and weight collected at one control (Giants Neck) and three heated stations are shown in Table 12. The study was designed to test the supposition that heated effluents might effect the food supply for oysters and thereby change growth patterns for these animals. Oysters were not indigenous to the Millstone area so growth may not be as good as could be expected where they occur naturally. It should be noted, also, that the water at the Quarry Cut site was extremely turbulent so that growth could have been impaired simply by this factor alone. 


\section{TABLE 12. Average Weight $(\mathrm{g})$ and Length $(\mathrm{mm})$ for Adult Oysters Held in Trays a t the Millstone Point Areal}

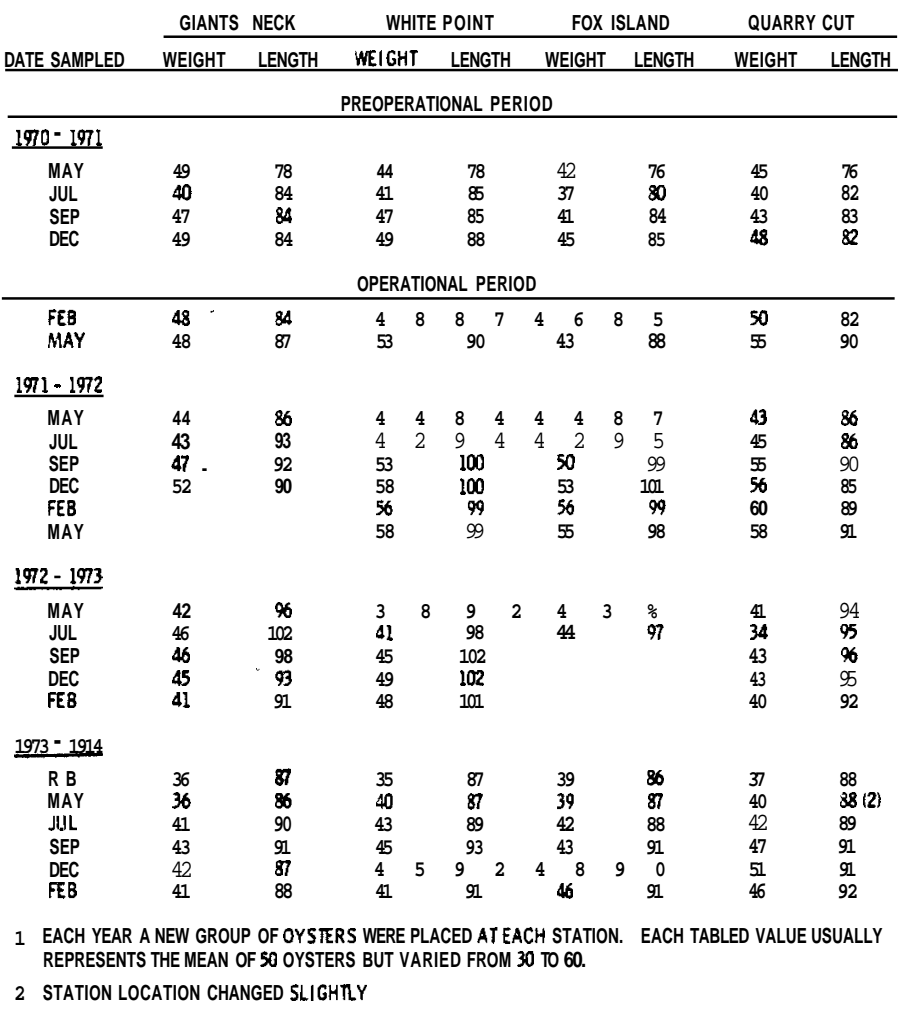

In order to visually assess changes at heated stations relative to the control, we have plotted the station differences (control-heated) for average weight and length in Figures 15 and 16, respectively. All three heated stations had oysters with average weights or lengths either nearly equal to or larger than those exhibited by oysters at Giants Neck during both the 1971-1972 and 1973-1974 periods. However, similar difference patterns were evident during preoperation except for the Fox Island station. During a long portion of 1972-1973 the reactor was not operational and the difference patterns obtained show slightly smaller animals at the heated stations relative to those from Giants Neck. 


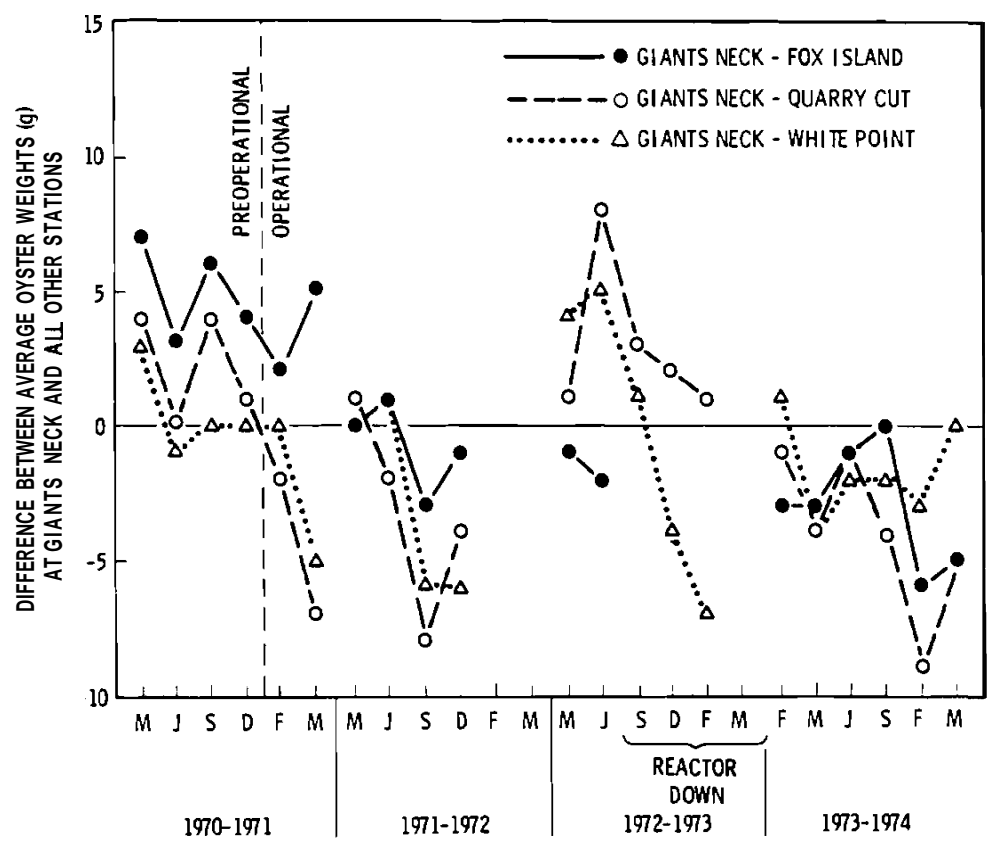

FIGURE 15. Difference Between Average Weight (g) for Adult Oyster at Giants Neck and Other Stations

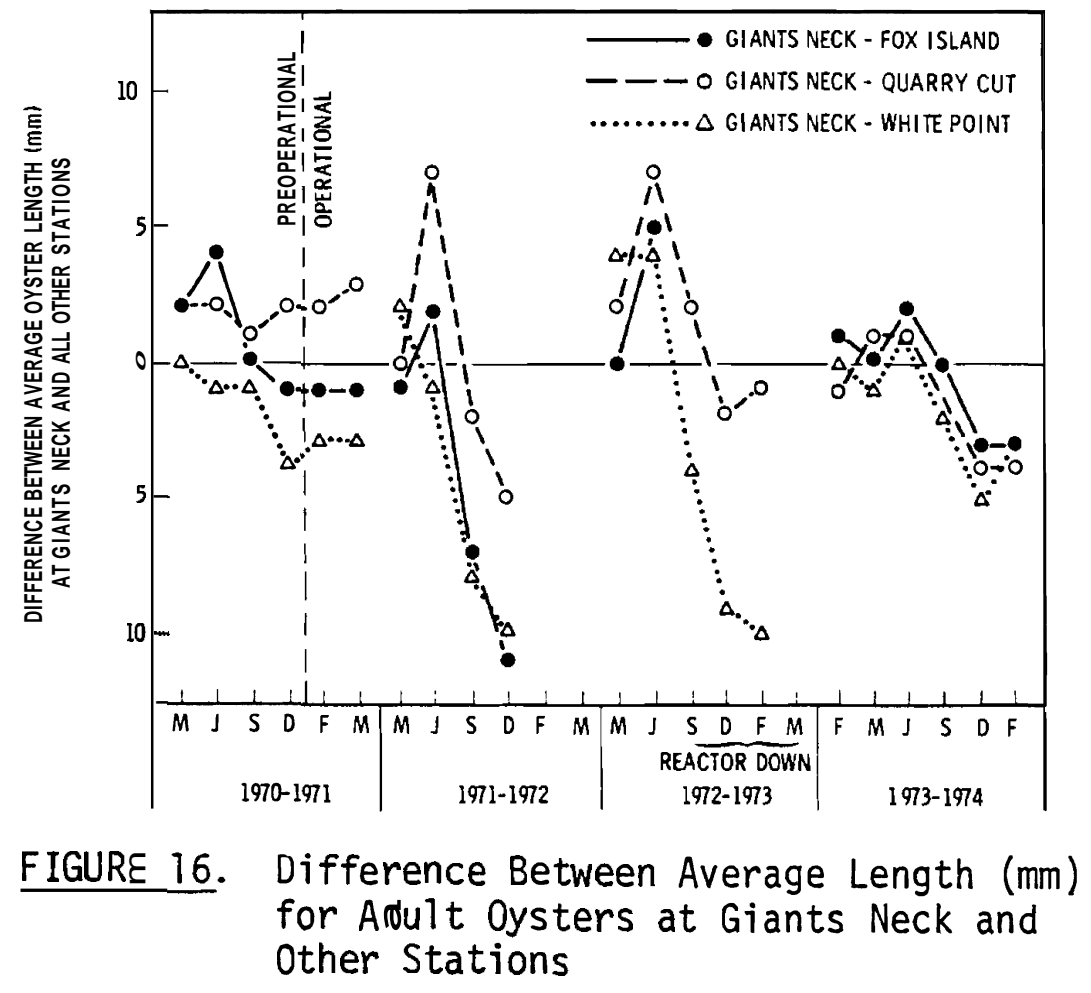


During the four "growing seasons" mean weights at Giants Neck declined (47, 46, 44, and 40 grams for the four respective growth seasons) while the weights for animals from heated stations generally either did not decline as far or actually increased relative to preoperational values (Table 13) except for 1972-1973 when the reactor was not operating for a long period. Without data from an additional control site, we cannot be sure that the declining weights at Giants Neck were normal for unheated areas. There is, however, the suggestion based only on a qualitative examination of the data that oyster growth was unaffected by the operation of the Millstone Plant. However, we cannot validate such an assertion.

Since both weight and length measurements were collected on the same animals over the entire study period, we investigated the linear relationships between the two measurements for each station to assess the usefulness of obtaining both measurements. Tabular results are in Table 14 and the data as well as an overall linear regression relationship are plotted in Figure 17. The latter regressions were calculated even though we realize that the independent variable (weight) was not measured without error which may invalidate $t$-test used.

TABLE 13. Statistics for "Growing Season" Weights and Lengths of Oysters at the Millstone Point Area

\begin{tabular}{|c|c|c|c|c|c|c|c|c|}
\hline \multirow{3}{*}{$\begin{array}{c}\begin{array}{c}\text { Date } \\
\text { Sampled }\end{array} \\
1970-1971 \\
\end{array}$} & \multirow{2}{*}{\multicolumn{2}{|c|}{ 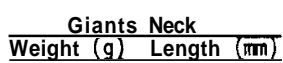 }} & \multicolumn{2}{|c|}{ White Point } & \multirow{2}{*}{\multicolumn{2}{|c|}{$\begin{array}{l}\text { Fox Island } \\
\text { Weight }(\mathrm{g}) \text { Length (mm) }\end{array}$}} & \multicolumn{2}{|c|}{ Quarry Cut } \\
\hline & & & leight (g) & Length (m) & & & Weight & ngth $(\mathrm{mm})$ \\
\hline & & & & & & & & \\
\hline Average & 46.8 & 83.5 & 47.3 & 85.5 & 42.3 & 83.0 & 46.8 & 82.5 \\
\hline $\begin{array}{l}\text { Standard } \\
\text { Deviation }\end{array}$ & 3.43 & 2.95 & 3.93 & 4.14 & 3.20 & 4.29 & 5.34 & 4.46 \\
\hline $1971-1972$ & & & & & & & & \\
\hline Average & 46.5 & 90.3 & 51.8 & 96.0 & 50.0 & 96.5 & 52.8 & 87.8 \\
\hline $\begin{array}{l}\text { Standard } \\
\text { Deviation }\end{array}$ & 4.04 & 3.10 & 7.11 & 6.29 & 5.83 & 5.05 & 7.08 & 2.48 \\
\hline $1972-1973$ & & & & & & & & \\
\hline Average & 44.0 & 96.0 & 44.2 & 99.0 & 43.5 & 96.5 & 40.2 & 94.4 \\
\hline $\begin{array}{l}\text { Standard } \\
\text { Deviation }\end{array}$ & 2.35 & 4.30 & 4.66 & 4.24 & -- & - & 3.70 & 1.52 \\
\hline $1973-1974$ & & & & & & & & \\
\hline Average & 39.8 & 88.2 & 41.5 & 89.8 & 42.8 & 88.8 & 43.8 & 89.8 \\
\hline $\begin{array}{l}\text { Standard } \\
\text { Deviation }\end{array}$ & 3.06 & 1.94 & 3.78 & 2.56 & 3.66 & 2.14 & 5.12 & 1.72 \\
\hline
\end{tabular}


TABLE 14. Linear Regressions for Average Adult Oyster

Weight on Oyster Length at Four Millstone

Point Area Stations

\begin{tabular}{|c|c|c|c|c|}
\hline Stations & Intercept & t-Statistic & Slope & $\underline{t-S t a t i s t i c}$ \\
\hline Giants Neck & 91.6 & $6.92 * \star$ & -0.57 & -0.19 \\
\hline White Point & 69.7 & $6.96 * *$ & 0.489 & $2.28 *$ \\
\hline Fox Island & 48.8 & 4.91 ** & 0.921 & $4.19 * *$ \\
\hline Quarry Cut & 91.9 & $12.50 * *$ & -0.075 & -0.48 \\
\hline Al| Combined & 76.8 & $15.00 " \cdot \cdot$ & 0.291 & $2.67^{\star \star}$ \\
\hline
\end{tabular}

Estimates are significantly different from zero (*, $\left.\mathrm{P}<0.05 ;{ }^{* *}, \mathrm{P}<0.01\right)$.

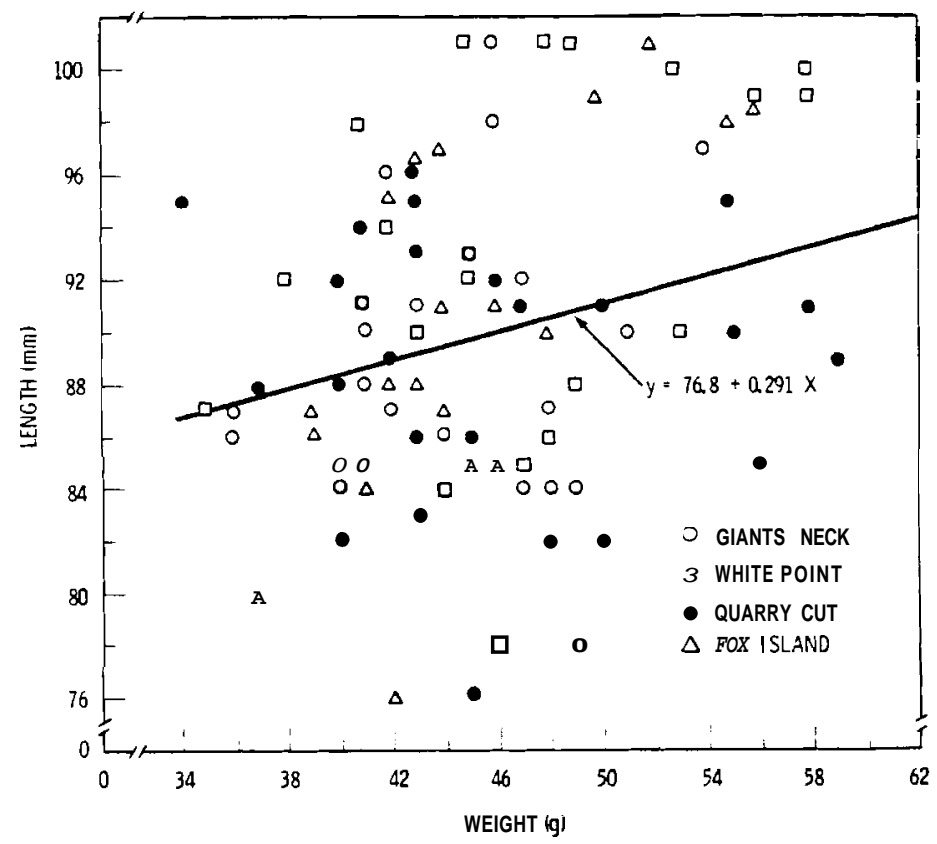

FIGURE 17. Relationship Between Average Weight $(\mathrm{g})$ and Length (mm) for Adult Oysters at the Millstone Point Area (1970-1974) 
The estimated linear regression slopes for Fox Island and White Point were positive and statistically significant while those for Giants Neck and Quarry Cut were not significantly different from zero. Intercept values were significantly different from zero, so that zero weight would not result in a zero length prediction for any station which is biologically impossible and indicates the linear regression model is incorrect. We did not recalculate the relationship with zero intercepts or investigate a power function model sometimes used in such comparisons. Since weights and lengths were poorly related at Giants Neck and QuarryCut but significantly related at the other two stations, it was appropriate to measure and evaluate both variables to assess change due to the operation of Ml1stone. However, the poorer relationship at the former two stations leads us to question the "representativeness" of animals grown at both these stations. The linear regression in Figure 17 indicates that deviations are extremely large and that any conclusions are tenuous.

\section{Summary}

The analysis of oyster weight data suggest that Millstone operations had no effect on oyster growth. We could not statistically validate this conclusion. Length and weight data were significantly correlated at two of four stations so both variables should be measured.

\section{TRACE METALS}

After Millstone Power Plant became operational, studies were initiated to determine trace metal levels in oysters, mussels and seawater. Mussels were indigenous to the Millstone area but apparently did not grow near the discharge station (Quarry Cut or Effluent Station) since no sample values were reported from that location. Oysters were not a normal resident so they were artificially maintained as biological monitors for trace metals. The data for the three trace metals found in highest concentrations in oysters are in Table 15 and the complete data set including mussel and seawater levels for the same metals are plotted in Figures 18-20. These figures show that the metal concentrations ( $\mathrm{ppm}$ ) in seawater would be difficult to quantitatively relate to those of either mussel or oyster tissue. 
The reason(s) is probably related to the fact that animals are subjected to amounts of trace metals in water which vary over orders of magnitude between quarterly sampling dates and that other metabolic factors related to season and life stage of the animal are involved. Interestingly, seawater from the Quarry location usually had soluble iron, copper and zinc levels no higher than Giants Neck whereas the Giants Neck station seawater was highest in insoluble iron for two of the three years sampled. In this latter case, concentrations ranged over two orders of magnitude over the three year period.

TABLE 15. Metal Concentrations (ppm) for Tray Grown Oysters Tissue at Millstone Nuclear Power Station

\begin{tabular}{|c|c|c|c|c|c|c|c|c|c|c|}
\hline \multirow[b]{2}{*}{$\begin{array}{c}\text { Date } \\
\text { Sampled } \\
\end{array}$} & \multicolumn{3}{|c|}{ Copper } & \multicolumn{3}{|c|}{ Iron } & \multicolumn{3}{|c|}{ Zinc } & \multirow{2}{*}{$\begin{array}{c}\text { Value } \\
\text { Plotted } \\
\text { (Figure }\end{array}$} \\
\hline & $\begin{array}{l}\text { Giants } \\
\text { Neck }\end{array}$ & $\begin{array}{c}\text { Fox } \\
\text { Is land } \\
\end{array}$ & $\begin{array}{c}\text { Quarry } \\
\text { Cut } \\
\end{array}$ & $\begin{array}{l}\text { Giants } \\
\text { Neck }\end{array}$ & $\begin{array}{l}\text { Fox } \\
\text { Is Tand } \\
\end{array}$ & $\begin{array}{l}\text { Quarry } \\
\text { Cut } \\
\end{array}$ & $\begin{array}{l}\text { Giants } \\
\text { Nêck }\end{array}$ & $\begin{array}{l}\text { Fox } \\
\text { Isiand } \\
\end{array}$ & $\begin{array}{c}\text { Quarry } \\
\text { cut } \\
\end{array}$ & \\
\hline \multicolumn{11}{|l|}{1972} \\
\hline May & - & 155 & 525 & - & 45 & 53 & - & 2440 & 1870 & QC-FI \\
\hline Sept & 75 & - & 205 & 50 & - & 58 & 1240 & - & 1595 & QC-GN \\
\hline \multicolumn{11}{|l|}{1973} \\
\hline May & 113 & 119 & 202 & 35 & 51 & 43 & 1090 & 1490 & 1430 & $\mathrm{QC}-\mathrm{GN}$ \\
\hline July & 95 & 75 & 370 & 48 & 37 & 87 & 1270 & 890 & 1440 & $\mathrm{QC}-\mathrm{GN}$ \\
\hline Sept & 100 & 159 & 470 & 50 & 62 & 112 & 1282 & 2283 & 2058 & $\mathrm{QC}-\mathrm{GN}$ \\
\hline Dec & 130 & 140 & 430 & 46 & 43 & 82 & 1650 & 1860 & 2150 & $\mathrm{QC}-\mathrm{GN}$ \\
\hline Feb & 104 & 40 & 247 & 26 & 23 & 35 & 1800 & 620 & 1270 & QC-GN \\
\hline \multicolumn{11}{|l|}{1974} \\
\hline May & - & 107 & 216 & - & 33 & 113 & - & 1495 & 1645 & QC-FI \\
\hline July & - & 67 & 248 & - & 31 & 64 & - & 1080 & 1790 & QC-FI \\
\hline Sept & - & 110 & 330 & - & 60 & 170 & - & 1740 & 2320 & QC-FI \\
\hline Dec & - & 98 & 357 & - & 46 & 60 & $\begin{array}{l}- \\
-\end{array}$ & 1530 & 2440 & QC-FI \\
\hline
\end{tabular}

${ }^{1} \mathrm{QC}=$ Quarry Cut

FI $=$ Fox Island

$\mathrm{GN}=$ Giants Neck 


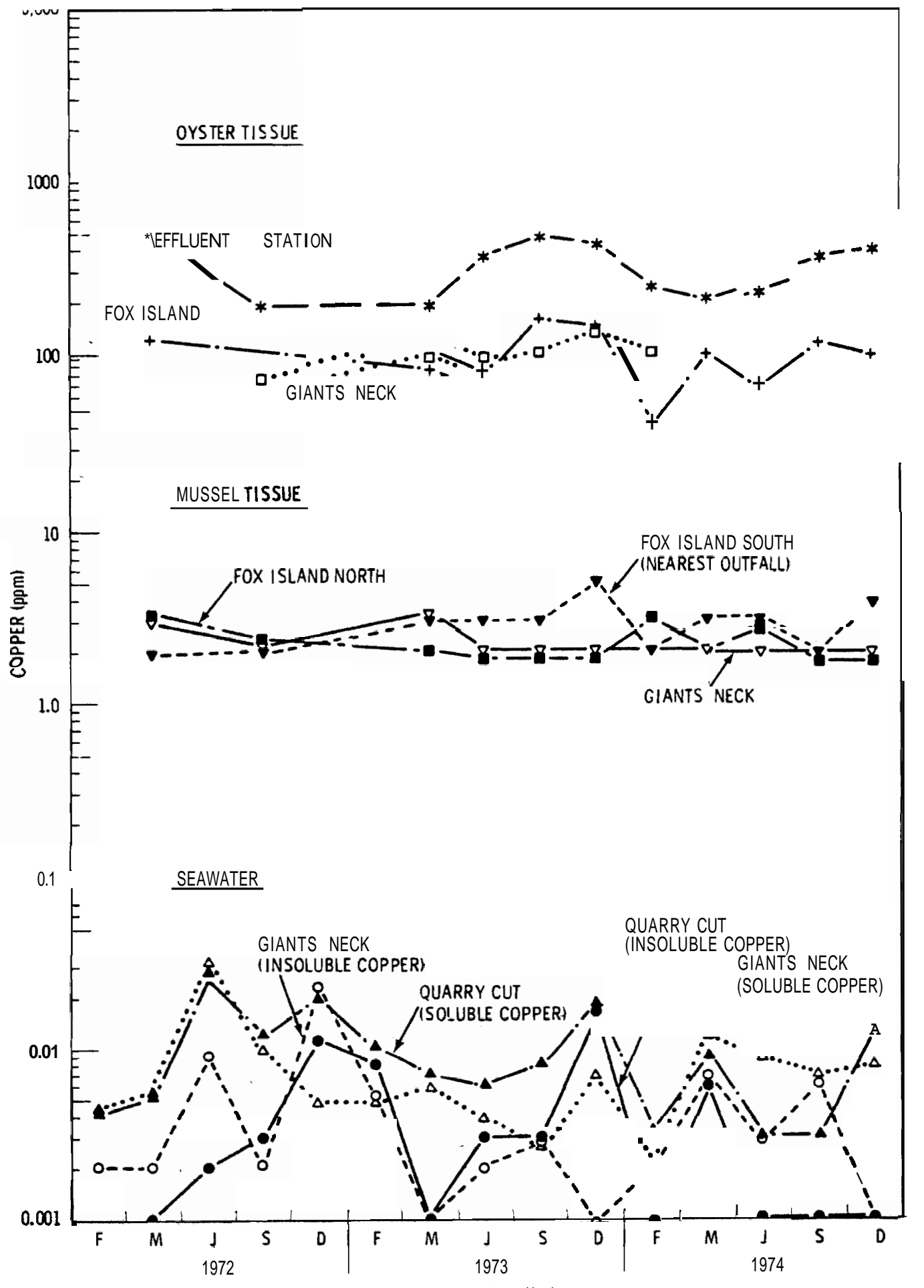

TIME (months)

FIGURE 18. Levels of Copper (ppm) in Oysters, Mussels and Seawater at Several Stations at Millstone Nuclear Power Station 


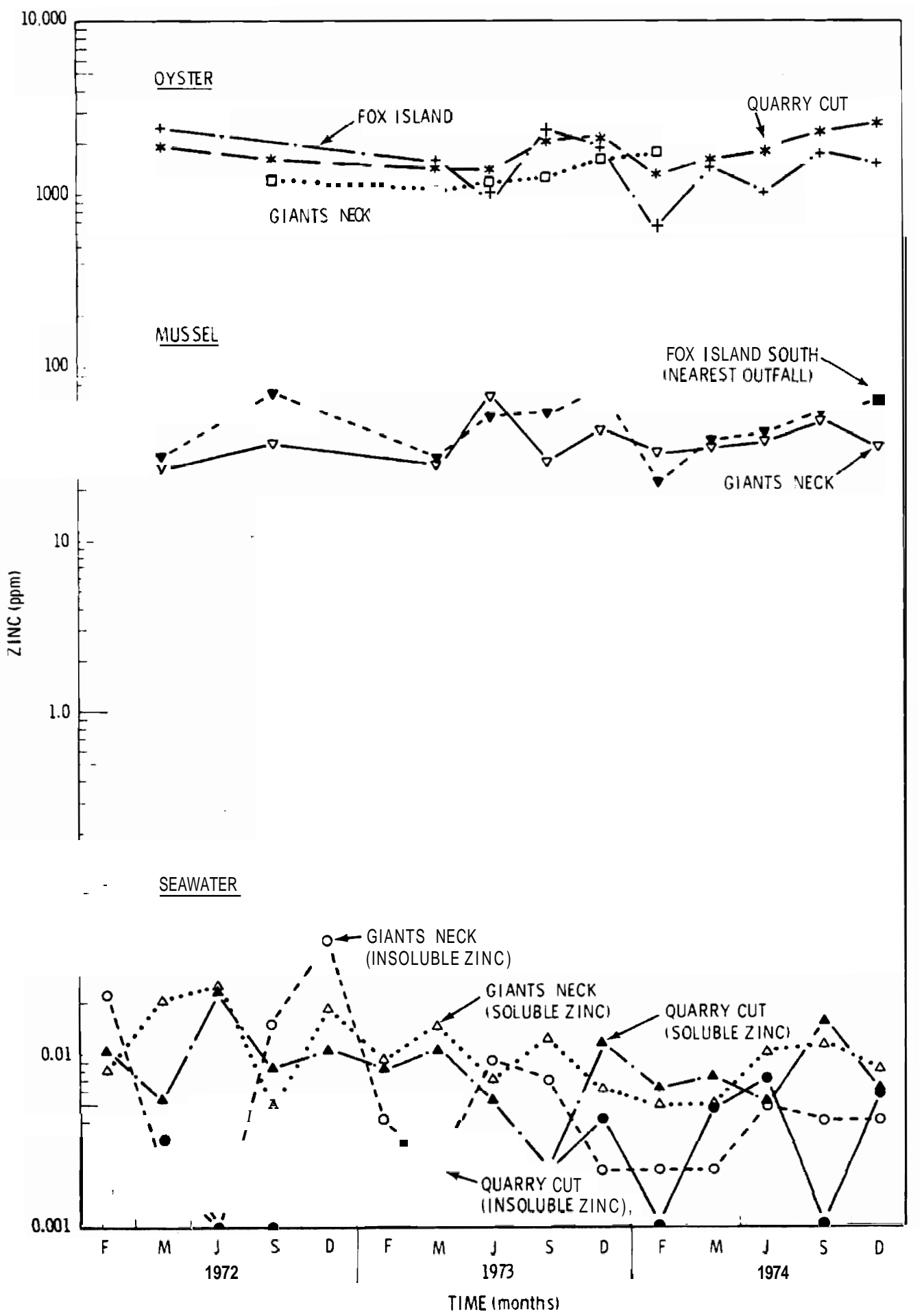

FIGURE 19. Levels of Zinc (ppm) in Oysters, Mussels and Seawater at Several Stations at Millstone Nuclear Power Station 


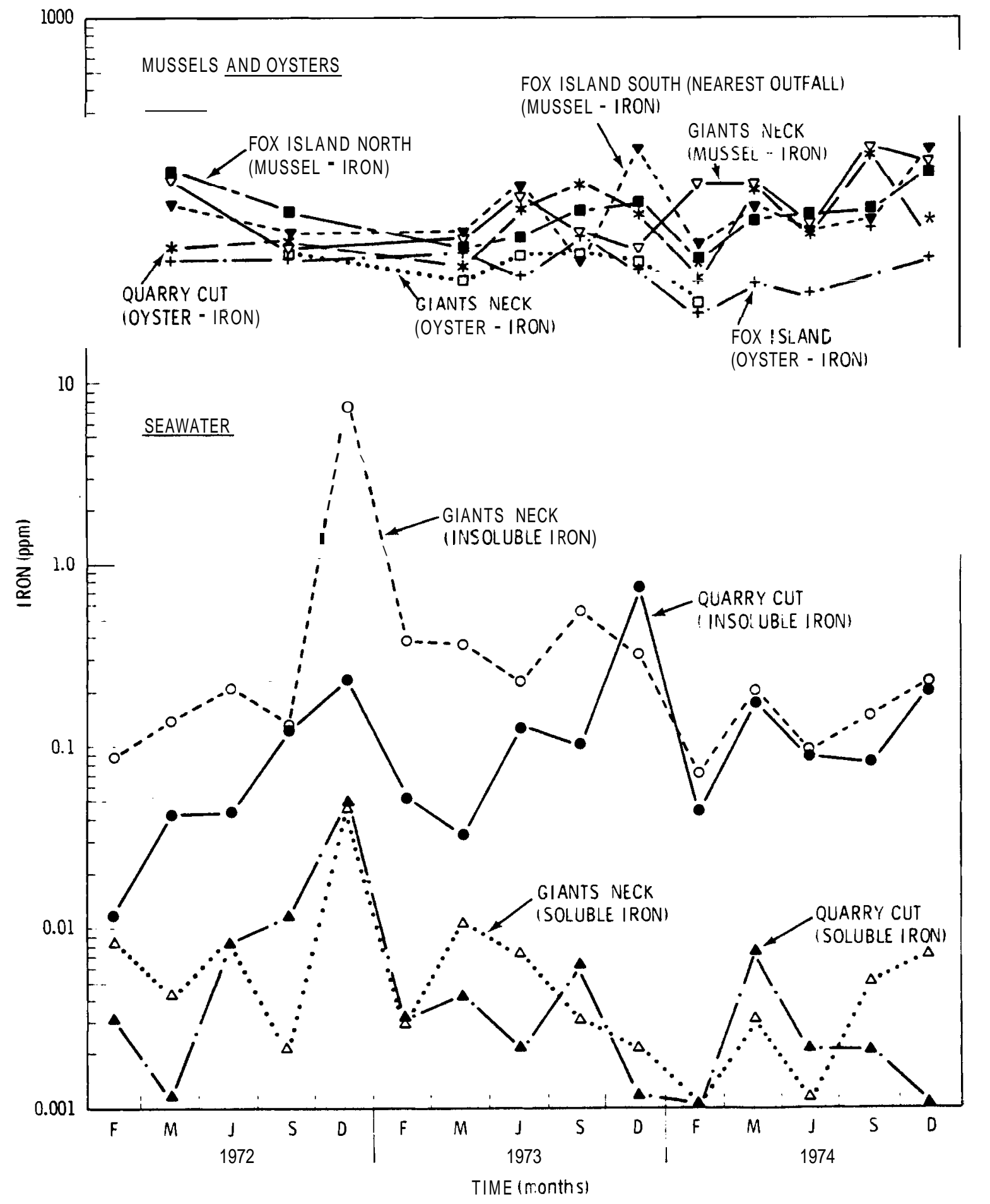

FIGURE 20. Levels of Iron (ppm) in Oysters, Mussels and Seawater at Several Stations at Millstone Nuclear Power Station 
A visual appraisal of the tissue concentrations in mussels and oysters (Figures 18-20) indicated that Quarry Cut oysters seemed to exhibit higher values than the control station. We calculated the concentration differences for Quarry Cut and Giants Neck, but used metal concentration in oyster from Fox Island when no data were reported for Giants Neck (Figure 21). The upper pane1 shows the large difference for copper concentration which was apparent in Figure 18 but the middle panel also shows that iron concentrations were consistently higher at the Quarry Station which was not clear from a cursory examination of Figure 20. Finally, the lower panel indicates tissue zinc values may be higher for oysters grown at the Quarry station but our use of Fox Island concentration data when Giants Neck values were unavailable may have affected the results (see Figure 19). The fact that a $95 \%$ confidence interval (use the summary statistics in Figure 21 ) does not include zero can be used as evidence to support an assertion that both copper and iron concentrations in oysters were significantly higher at the Quarrystation than at Giants Neck, but that zinc concentrations lacked consistency and were not significantly different. However, the unknown serial correlation structures of the differences may invalidate the confidence intervals.

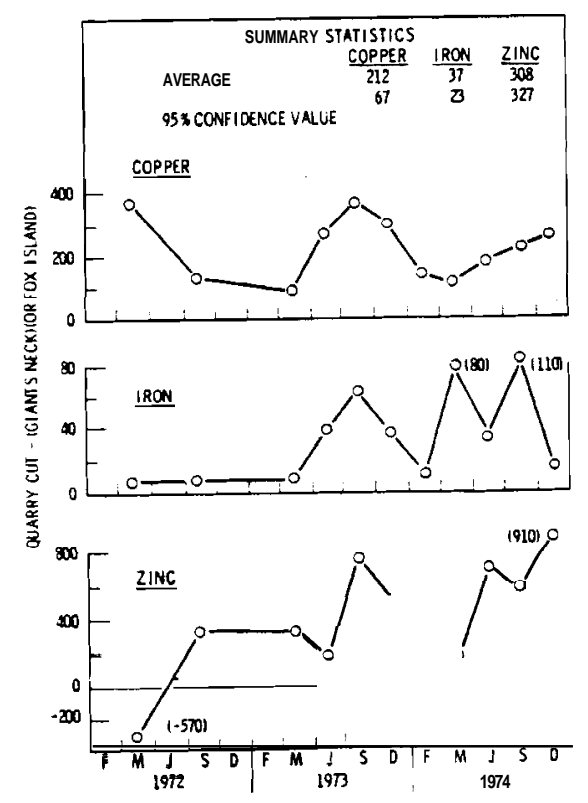

FGURE 21. Differences (ppm) Between Copper, Zinc and Iron Levels in Oysters a t Giants Neck or Fox Island and Quarry Cut Stations 


\section{$\underline{\text { Summary }}$}

We could not relate oysters and mussels tissue levels of copper, iron and zinc to those of seawater at any station. Both copper and iron levels were significantly $(\mathrm{P}<0.05)$ higher at the Quarry station compared to the control station. However, levels in organisms grown at Fox Island were sometimes substituted when the data were unavailable at Giants Neck (control), so our results can be questioned.

\section{SHOREZONE FISH (BEACH SEINING)}

The total number of shore-zone fish caught in beach seines for the six years of data collection are arranged by species and station in Table 16. Equal fishing effort was expended at each station in each year. Only the fourteen most numerous species are listed even though twenty additional species were caught. However, only 84 individuals or less of these latter species were caught during the entire six years of study. We have evaluated data obtained at Giants Neck, Bay Point, Jordan Cove and White Point because these stations were monitored for the entire study period. Table 16 shows more fish were caught at Jordan Cove while catches at White Point and Giants Neck were of intermediate size and Bay Point was clearly the location where the fewest shore-zone fish were caught. Even though similar sized catches were obtained at Giants Neck and White Point, they were composed of differing numbers of the same or of completely different species. For example, Figures 22 and $\mathbf{2 3}$ show that the temporal catch distribution was different at White Point and Giants Neck for total catch of Menidia menidia and Fundul us majal is respectively [i.e., the total numbers of either species caught at White Point or Giants Neck on the same sampling date differed markedly and disproportionantly (with respect to total catch) on that date]. The reason for the lack of temporal and spacial consistency are probably related to differences in habitat and characteristics of each station (Table 17). The quantitative problems in assessing change (already formidable with species such as fish because catch data are variable) relative to a control station are even more difficult than usual when such large differences in station characteristics (and thus species likely to frequent each area) are 
TABLE 16. Totals for the Most Numerous Species Caught in Seine Haulsl at the Millstone Point Area

\begin{tabular}{|c|c|c|c|c|c|c|c|c|}
\hline Species & $\begin{array}{c}\text { Giants }{ }^{2} \\
\text { Neck }\end{array}$ & $\begin{array}{l}\text { Bay } \\
\text { Point } \\
\end{array}$ & $\begin{array}{l}\text { Jordan } \\
\text { Cove } \\
\end{array}$ & $\begin{array}{l}\text { White }{ }^{2} \\
\text { Point }\end{array}$ & $\begin{array}{l}\text { seaside }^{3} \\
\text { Point }\end{array}$ & $\begin{array}{c}\text { Cresent }^{3} \\
\text { Beach } \\
\end{array}$ & $\begin{array}{l}\text { sandy } \\
\text { Point }\end{array}$ & Total \\
\hline Henta nenta & 8050 & 700 & 40807 & 5080 & 341 & 212 & 1978 & 57168 \\
\hline Fundulus majal is & 261 & 1 & 4173 & 711 & 1 & 1 & 789 & 5937 \\
\hline Brevoortia tyrannus & 95 & 1357 & 1180 & 1679 & 2 & 1 & -- & 4314 \\
\hline Fundulus heteroclitus & 159 & 1 & 3345 & 444 & -- & 147 & 1598 & 5694 \\
\hline Menidia beryl lina & 580 & 16 & 633 & 534 & 84 & 74 & 729 & 2650 \\
\hline Apel tes guadracus & 8 & 3 & 1163 & 17 & 1 & 3 & 241 & 1436 \\
\hline$\underline{\text { Pungitius pungi tius }}$ & 9 & -- & 727 & 4 & -- & 3 & -- & 743 \\
\hline Ammodytes americanus & 170 & 5 & -- & 3108 & 75 & 10 & 4 & 3372 \\
\hline Mugil cephalus & 1231 & $-\cdot$ & 279 & -- & 12 & 1 & -- & 1523 \\
\hline Cyprinodon variegatus & 287 & -- & 240 & 45 & 2 & 2 & 8 & 584 \\
\hline Gasterosteus aculeatus & 22 & 2 & 175 & 31 & 24 & -- & 1 & 255 \\
\hline Anguilla rostrata & 35 & -- & 127 & 1 & -- & -- & 2 & 165 \\
\hline Synanathus fucus & 25 & 23 & 15 & 16 & 4 & 12 & 8 & 103 \\
\hline Alosa aestivalis & 1 & 55 & - & 1 & -- & 27 & - & 84 \\
\hline TOTALS & 10933 & 2163 & 52864 & 11671 & 546 & 473 & 5358 & 4028 \\
\hline
\end{tabular}

Efforts (Number of Samplings) were the same in each year $(4,5,5,5,5$, and 6 sampling dates per year for 1969-1974).

${ }_{3}^{2}$ Sampled since May 1969

Sampled since February 1973

Sampled since February 1975.

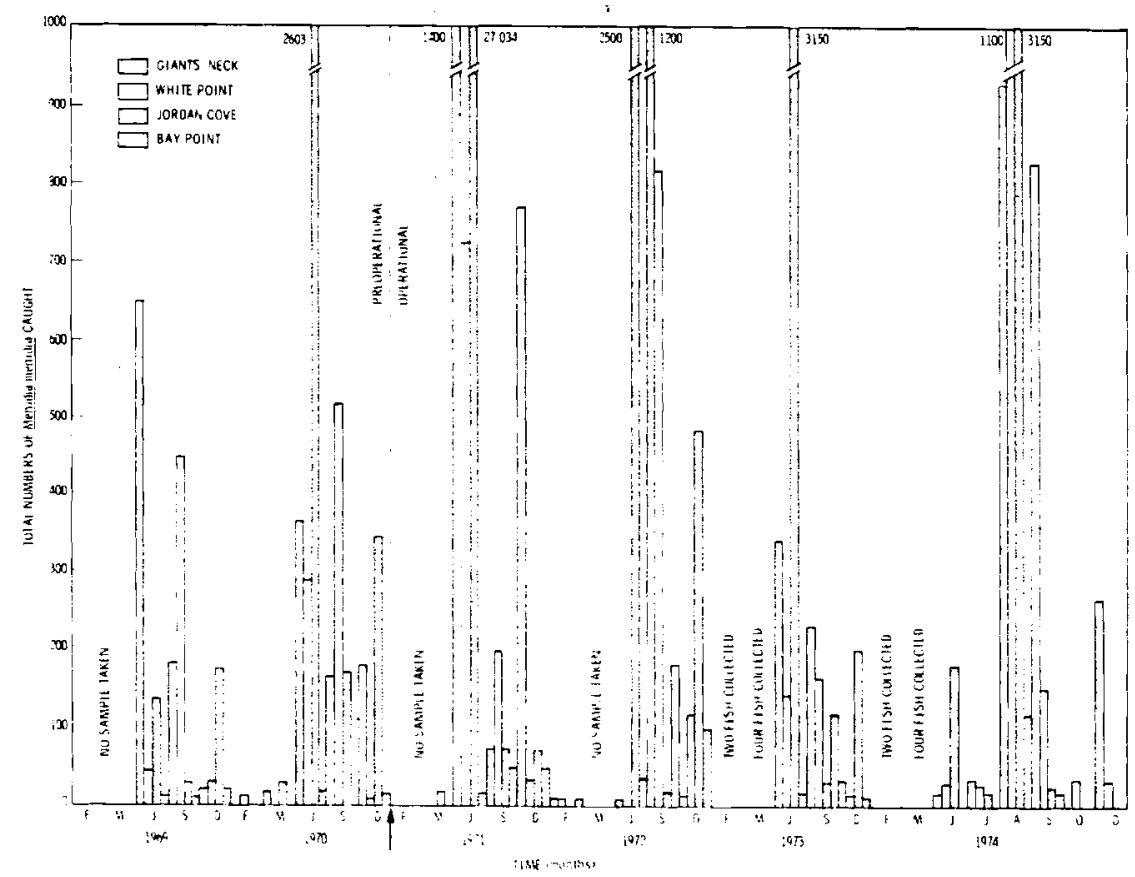

FIGURE 22. Total Numbers of Menidia menidia Caught Using Bag Seine Collections at Four Stations During 1969-1974 in the Millstone Point Area 


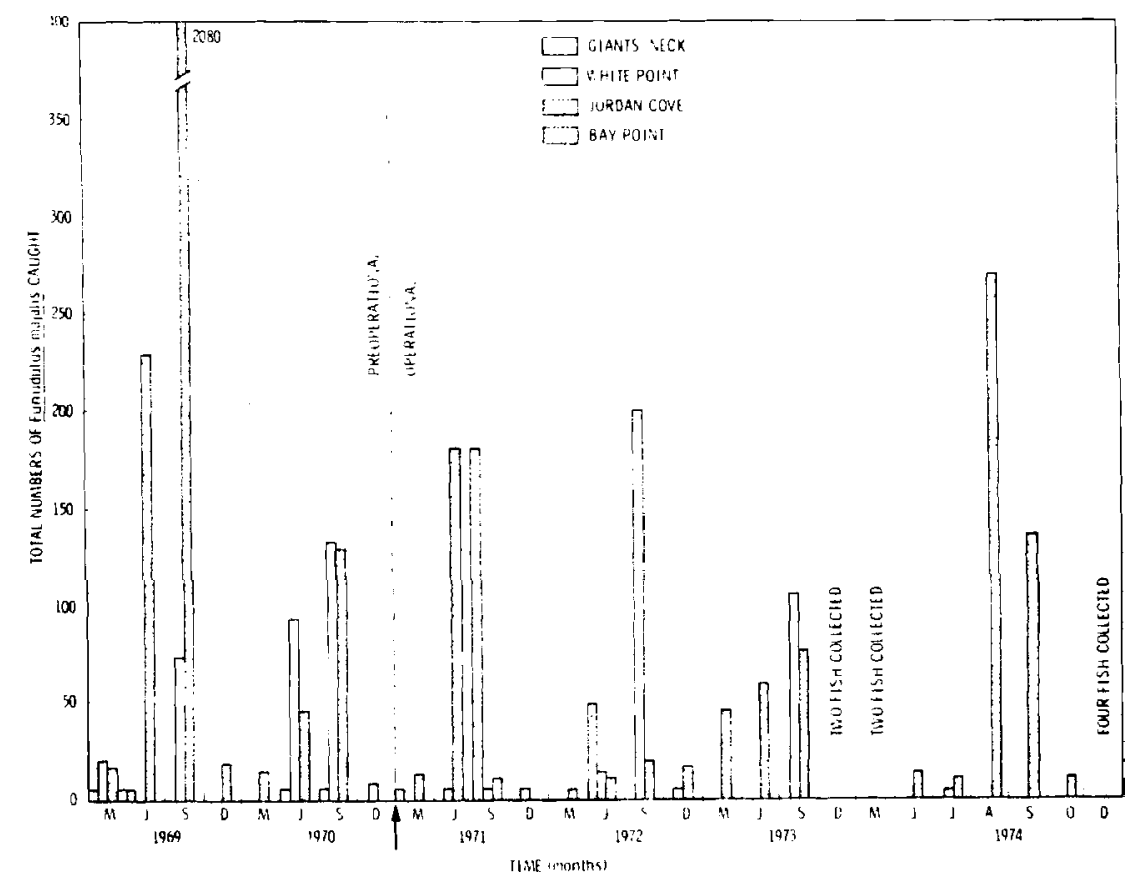

FIGURE 23. Total Number of Fundulus majalis Caught Using Bag Seine Collections at Four Stations During 1969-1974 in the Mi11stone Point Area

TABLE 17. Physical Characteristics of Beach Seine Stations at Millstone Point Area

\begin{tabular}{|c|c|c|c|c|c|}
\hline Location & $\begin{array}{r}\text { Exposure } \\
\text { Direction }\end{array}$ & Wave Action & Bottom & Vegetation & Comments \\
\hline Giants Neck & Southern & Protected & $\begin{array}{l}\text { Medium to coarse } \\
\text { Some Rocks }\end{array}$ & Algae and detritus & $\begin{array}{l}\text { Control-Public } \\
\text { Beach Comparable } \\
\text { to White Point }\end{array}$ \\
\hline Bay Point & South-Southwest & Heavy & $\begin{array}{l}\text { Coarse Sand } \\
\text { Rock Rubble }\end{array}$ & None & $\begin{array}{l}\text { Most Exposed to } \\
\text { Surf }\end{array}$ \\
\hline Jordan Cove & Southeast & Little & $\begin{array}{l}\text { Silt, Sand, and } \\
\text { Few Rocks }\end{array}$ & Eel Grass & $\begin{array}{l}\text { Some Freshwater } \\
\text { Runoff; Bottom } \\
\text { Often Exposed }\end{array}$ \\
\hline White Point & Southeast & $\begin{array}{l}\text { Moderate- } \\
\text { Breakwater }\end{array}$ & Medium Sand & Little & $\begin{array}{l}\text { Some Brakish } \\
\text { Freshwater Runoff }\end{array}$ \\
\hline Seaside Point & South & Heavy & $\begin{array}{l}\text { Medium to Fine } \\
\text { Sand }\end{array}$ & None & --- \\
\hline Cresent Beach & Eastern & Moderate & Medium Sand & None & -- \\
\hline
\end{tabular}


superimposed on the experimental design. On the other hand, selection of such different areas probably assured that almost all shore-zone fish species present in the Millstone areas would be identified, but reduced sampling frequencies, compared to those actually used, could have been employed for this purpose. Figures 22 and 23 also show that seining in February and May of each year did not result in a large enough catch of either species to be useful in assessing change. This point is emphasized in Figure 24 where total fish caught are plotted as a function of time for the control (Giants Neck) and most productive heated stations (Jordan Cove). Again, similar numbers of fish were usually not caught at the same time at the two stations and the numbers caught during February and May sampling periods were small. Moreover, this figure also indicates that a single December effort does not give catches large enough to be useful in detecting changes. In order to obtain adequate numbers of fish whereby an existing change could be detected, it appears that seining effort should be allocated to the July through September period.

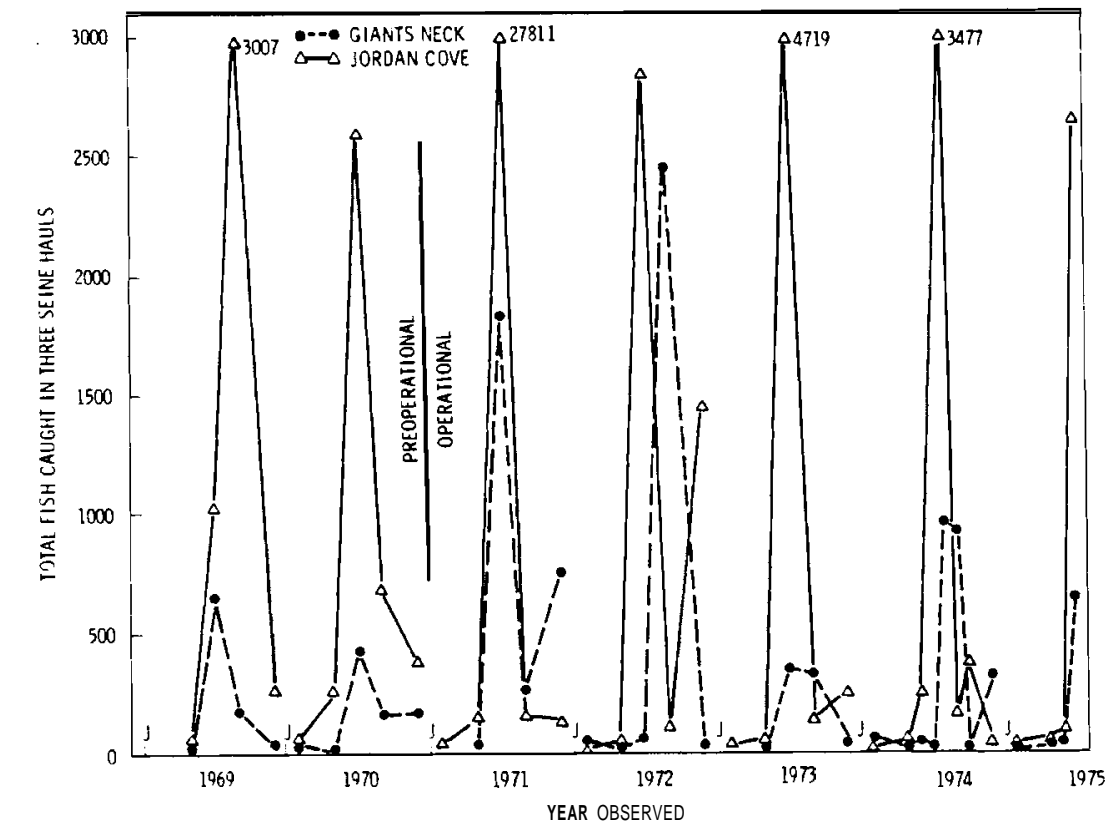

FIGURE 24. Total Fish Caught in Three Seine Hauls at Giants Neck and Jordan Cove (1969-1975) 
In order to assess changes in shore-zone fish numbers which might be associated with Millstone operations, we calculated the ratio of Giants Neck to Jordan Cove or White Point catches for total fish, the two major species (Fundul us majalis and Menidia menidia) and one "less abundant" species (Gasterosteus aculeatus). These results are shown in Table 18. A t-test of logarithmically transformed ratios showed no significant differences between the preoperational and operational periods (not an unexpected finding considering the size of the coefficients of variation shown in Table 18). However, the mean Giants Neck - Jordan Cove ratio increased during the operational period compared to the preoperational for total fish and the two "abundant" species. In two of three similar comparisons the Giants Neck - White Point ratio also increased. Still, the data were statistically inconclusive when viewed as station ratios compared for the two periods, and because of the large coefficients of variation, they would likely remain some even with more sampling dates within the preoperational and operational periods. However, if data for additional sampling stations had been available for control-heated stations pairs, and the increases noted above were also observed, a nonparametric test could possible be used which might potentially detect such a change. Ratios calculated for the less abundant species were not useful because fish were usually caught at one station but not the other (i.e. resulting in zero or infinite ratios).

TABLE 18. Arithmetic Means of Preoperational and Operational Beach Seine Station Ratios for Three Selected Species and all Fish at Millstone Point Area

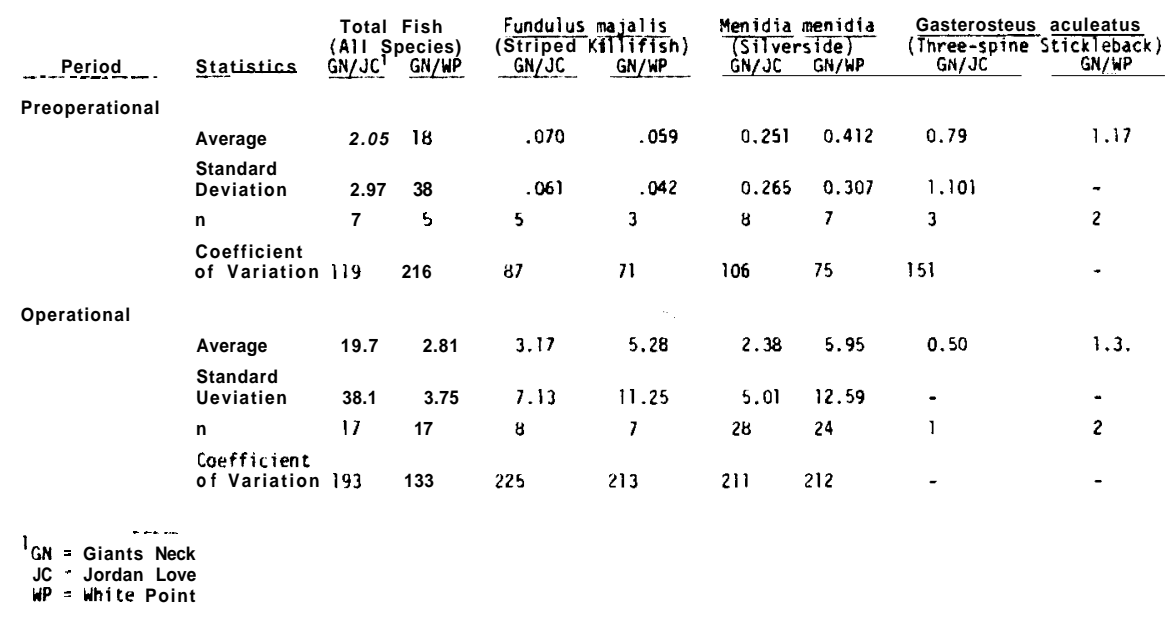


Another, more common way to evaluate the data, is to compare yearly averages for preoperational and operational years for each station. One should expect high coefficients of variation because "seasonal" effects are included (which may be removed by time-series methods when many cycles of data with seasonal components are available). We have calculated the means and standard deviations for two preoperational and one operational year (Table 19). Except for data obtained at Bay Point in 1960, the coefficients of variation would be greater than $100 \%$ and are not markedly different from those in Table 18. We also calculated means for the summer period of 1974 to attempt to remove "seasonal variability" since more fish were caught during this time than in the other months. Table 19 shows that even though mean values were much larger, respective standard deviations were still very large (i.e. greater than $100 \%$ of the means). Thus, further statistical analysis of this data is probably unwarranted.

$\underline{\text { Summary }}$

It appears that statistical variation was so high, that a very large sampling effort would be necessary to detect a change in shore-zone fish numbers which could be attributed to the operation of Millstone. Continued sampling at the current level of effort probably is not worthwhile. If detecting change in numbers of these fish is deemed important, a considerably expanded program will be necessary, but the program should be intensive in July-September and should incl ude additional control-heated stations pairs. We are not aware of any economical or cost-effective way to assess the meaning of changes in shore-zone fish numbers collected to changes in populations.

TABLE 19. Yearly and Summer Means [Total of three $(30 \mathrm{~m})$ Seine Hauls] for Total Fish Caught at the Mil 1stone Point Area

\begin{tabular}{|c|c|c|c|c|c|c|c|c|c|c|c|c|c|c|}
\hline \multirow[b]{3}{*}{ Year } & \multicolumn{14}{|c|}{ All Data } \\
\hline & \multicolumn{3}{|c|}{$\underline{\text { SEASIDE }}$} & \multicolumn{3}{|c|}{ WHITE POINT } & \multicolumn{3}{|c|}{ JORDAN COVE } & \multicolumn{3}{|c|}{ 'BAY POINI } & \multicolumn{2}{|c|}{ GIANTS NECK } \\
\hline & $n$ & $\bar{x}$ & SD & $n$ & $\bar{x}$ & SD & $n$ & $\bar{x}$ & SD & $n$ & $\underline{\bar{x}}$ & sn & ח & SD \\
\hline 1969 & - & - & - & 4 & 405 & 455 & & 081 & 1349 & 4 & 6.5 & 4.2 & 4216 & 309.3 \\
\hline 1970 & - & - & - & 5 & 243 & 329 & 5 & 792. & 1081 & & 60 & 572 & 5159 & 179.3 \\
\hline \multirow[t]{2}{*}{1974} & 8 & 8.0 & 12.2 & 8 & 203. & 376 & 8 & 840 & 1331 & 8 & 19.0 & 41.3 & 8295 & 418 \\
\hline & \multicolumn{14}{|c|}{ June Through September } \\
\hline 1974 & 4 & 14 & 15 & 4 & 355 & 512 & & 683 & 1714 & 4 & 35 & 58 & 4493 & 531 \\
\hline
\end{tabular}




\section{MPNGEMENT}

The data for the most important (economical ly) fish species impinged/day as well as a11 organisms impinged/day are arranged by month for 1972-1974 in Tables 20-22. Over the three year period nearly one-fourth of the total organisms impinged were made up of those economically important fish species, but in certain months they represented differing fractions of total impingement depending on the observational year (Figure 25). If numbers of shellfish and squid as well as other fish species impinged are summed, about $80 \%$ of the total impingement for all three years can be accounted for (Tables 2325). These tables also show that a larger fraction of shellfish and economically important fish were impinged compared to other fish during the three year study period. However, the two classifications, over $7.6 \mathrm{~cm}$ contained a smaller fraction of shellfish except in 1972 when a large fraction (52\%) was impinged. When total catch/per day was computed for each year and for all three years, no particularly discrepant values were observed (i.e. 67.31/day overall and 56.9, 88.5 and 53.8 organisms/day for 1972-1974, respectively). $\mathrm{N}$ extremely divergent values were observed when data were examined monthly (clear bars in Figure 25). Catches of over 100 organisms 1 day generally occurred in the summer, but in no particular month was special. During 1971, a large summer impingement of menhaden (50 mil 1ion) was observed, so extraordinary impingements have occurred. Finally, we have prepared Figures 26-28 which summarize the percentage values shown at the bottom of Tables 23-25. Economically important fish constitute a large fraction of the greater than $15.2 \mathrm{~m}$ category, but represent few fish per day (10, 6, and 5 fish/day for 1972-1974). Shellfish survive at a high rate after impingement so the numbers of these species impinged may be of little biological importance.

$\underline{\text { Summary }}$

Maximum numbers of organisms/day were impinged during 1973. Lesser numbers were caught per day in other years. Over $20 \%$ of the total organisms survive impingement at a high rate (shellfish) and only 20-30\% were economically important fish species. The importance of the observed impingement is 
TABLE 20. Total Impingement/Month and Average Impingement/Day for the Most Numerous Economically Important Fish Species for 1972 at Millstone Nuclear Power Station

\begin{tabular}{|c|c|c|c|c|c|c|c|c|}
\hline MONTH & $\begin{array}{r}\text { ARANTIC } \\
\text { ARANAEN }\end{array}$ & $\begin{array}{l}\text { WINTER } \\
\text { WUAER }\end{array}$ & $\begin{array}{l}\text { WINDOWPANE } \\
\text { ROUNDER }\end{array}$ & $\begin{array}{l}\text { BLUEBACK } \\
\text { HERRING }\end{array}$ & TOTAL & $\begin{array}{l}\text { NO. OF } \\
\text { DAYS }\end{array}$ & $\begin{array}{c}\text { TOTAL } \\
\text { ECONOMICALLY } \\
\text { IMPORTANT } \\
\text { FISHIDAY }\end{array}$ & $\begin{array}{c}\text { TOTAL ALL } \\
\text { ORGANISMSIDAY }\end{array}$ \\
\hline JANUARY & 0 & 117 & 0 & 33 & 150 & 11 & 14 & 16 \\
\hline FEBRUARY & 0 & 35 & 0 & 0 & 35 & 7 & 5 & 8 \\
\hline MARCH & 0 & 266 & 14 & 38 & 318 & 13 & 24 & 57 \\
\hline APRIL & 19 & 324 & 18 & 22 & 383 & 23 & 17 & 32 \\
\hline MAY & 344 & 292 & 52 & 3 & 691 & 28 & 25 & 45 \\
\hline JUNE & 13 & 188 & 385 & 0 & 586 & 30 & 20 & 84 \\
\hline JULY & 9 & 82 & 250 & 4 & 345 & 25 & 14 & 79 \\
\hline AUGUST & 38 & 93 & 508 & 900 & 1539 & 30 & 51 & 127 \\
\hline SEPTEMBER & 0 & 106 & 260 & 188 & 554 & 19 & 29 & 83 \\
\hline OCTOBER & 1 & 251 & 68 & 450 & 770 & 29 & 27 & 60 \\
\hline NOVEMBER & 0 & 37 & 0 & 66 & 103 & 30 & 3 & 21 \\
\hline DECEMBER & 0 & 119 & 0 & 2 & 121 & 30 & 4 & 14 \\
\hline TO & 424 & 1910 & 1555 & 1706 & 5595 & 275 & 20 & 57 \\
\hline
\end{tabular}

TABLE 21. Total Impingement/Month and Average Impingement/Day for the Most Numerous Economically Important Fish Species for 1973 at Millstone Nuclear Power Station

\begin{tabular}{|c|c|c|c|c|c|c|c|c|}
\hline MONTH & $\begin{array}{r}\text { ATLANTIC } \\
\text { MENHADEN }\end{array}$ & $\begin{array}{l}\text { WINTER } \\
\text { FLOUNDER }\end{array}$ & $\begin{array}{l}\text { WINDOWPANE } \\
\text { FLOUNDER }\end{array}$ & $\begin{array}{c}\text { BLUEBACK } \\
\text { HERRING } \\
\end{array}$ & TOTAL & $\begin{array}{l}\text { NO. OF } \\
\text { DAYS } \\
\end{array}$ & $\begin{array}{c}\text { TOTAL } \\
\text { ECONOMICALLY } \\
\text { IMPORTANT } \\
\text { FISHIDAY } \\
\end{array}$ & $\begin{array}{c}\text { TOTAL ALL } \\
\text { ORGANISMSIDAY } \\
\end{array}$ \\
\hline JANUARY & 32 & 874 & 11 & 0 & 918 & 27 & 34 & 56 \\
\hline FEBRUARY & 86 & 872 & 26 & 2 & 986 & 28 & 35 & 60 \\
\hline MARCH & 22 & 894 & 13 & 2 & 931 & 31 & 30 & 56 \\
\hline APRIL & 1 & 325 & 17 & 1 & 344 & 30 & 11 & 69 \\
\hline MAY & 0 & 199 & 17 & 4 & 220 & 31 & 7 & 79 \\
\hline JUNE & 1 & 39 & 26 & 1 & 67 & 30 & 2 & 64 \\
\hline JULY & 1 & 86 & 46 & 9 & 142 & 31 & 5 & 61 \\
\hline AUGUST & 1 & 23 & 11 & 48 & 83 & 31 & 3 & 36 \\
\hline SEPTEMBER & 8 & 17 & 0 & 8 & 33 & 30 & 1 & 22 \\
\hline OCTOBER & 1 & 20 & 3 & 10 & 34 & 31 & 1 & 26 \\
\hline NOVEMBER & 30 & 223 & 17 & 23 & 293 & 30 & 10 & 67 \\
\hline DECEMBER & 7 & 147 & 25 & 5 & 184 & 31 & 6 & 39 \\
\hline & 190 & 3719 & 213 & 113 & 4235 & $36 \mathrm{I}$ & 12 & 53 \\
\hline
\end{tabular}


TABLE 22. Total Impingement/Month and Average Impingement/Day for the Most Numerous Economically Important Fish Species for 1974 at Millstone Nuclear Power Station

\begin{tabular}{|c|c|c|c|c|c|c|c|c|}
\hline MONTH & $\begin{array}{l}\text { ATAATIC } \\
\text { MENHADEN }\end{array}$ & $\begin{array}{l}\text { WINTER } \\
\text { FLOUNDER }\end{array}$ & $\begin{array}{l}\text { WINDOWPANE } \\
\text { FLOUNDER }\end{array}$ & $\begin{array}{l}\text { BLUEBACK } \\
\text { HERAING }\end{array}$ & TOTAL & $\begin{array}{l}\text { No. OF } \\
\text { DAYS }\end{array}$ & $\begin{array}{c}\text { TOTAL } \\
\text { ECONOMICALLY } \\
\text { IMPORTANT } \\
\text { FISHIDAY } \\
\end{array}$ & $\begin{array}{c}\text { TOTAL ALL } \\
\text { ORGANISMSIDAY }\end{array}$ \\
\hline JANUARY & 72 & 1200 & 5 & 0 & 1277 & 31 & 41 & 63 \\
\hline FEBRUARY & 43 & 1530 & $\mathbf{B}$ & 1 & 1587 & 28 & 57 & 89 \\
\hline MARCH & 10 & 1622 & 74 & 13 & 1719 & 31 & 55 & 97 \\
\hline APRIL & 50 & 818 & 113 & 20 & 1001 & 30 & 32 & 96 \\
\hline MAY & 4 & 276 & 159 & 10 & 729 & 31 & 24 & 102 \\
\hline JUNE & 1 & 90 & 76 & 3 & 170 & 30 & 6 & 85 \\
\hline JULY & 16 & 36 & 46 & 2 & 100 & 31 & 3 & 41 \\
\hline AUGUST & 609 & 69 & 57 & 34 & 769 & 29 & 27 & 93 \\
\hline SEPTEMBER & 111 & 63 & 36 & 31 & 241 & 26 & 9 & 136 \\
\hline OCTOBER & 212 & 93 & 48 & 86 & 439 & 29 & 15 & 150 \\
\hline NOVEMBER & 237 & 90 & 58 & 58 & 443 & 28 & 16 & 90 \\
\hline DECEMBER & 82 & 268 & 30 & 0 & 380 & 30 & 13 & 51 \\
\hline TOTAL & 1447 & 6155 & $\overline{715}$ & $\overline{258}$ & 8575 & 354 & 24 & 90 \\
\hline
\end{tabular}

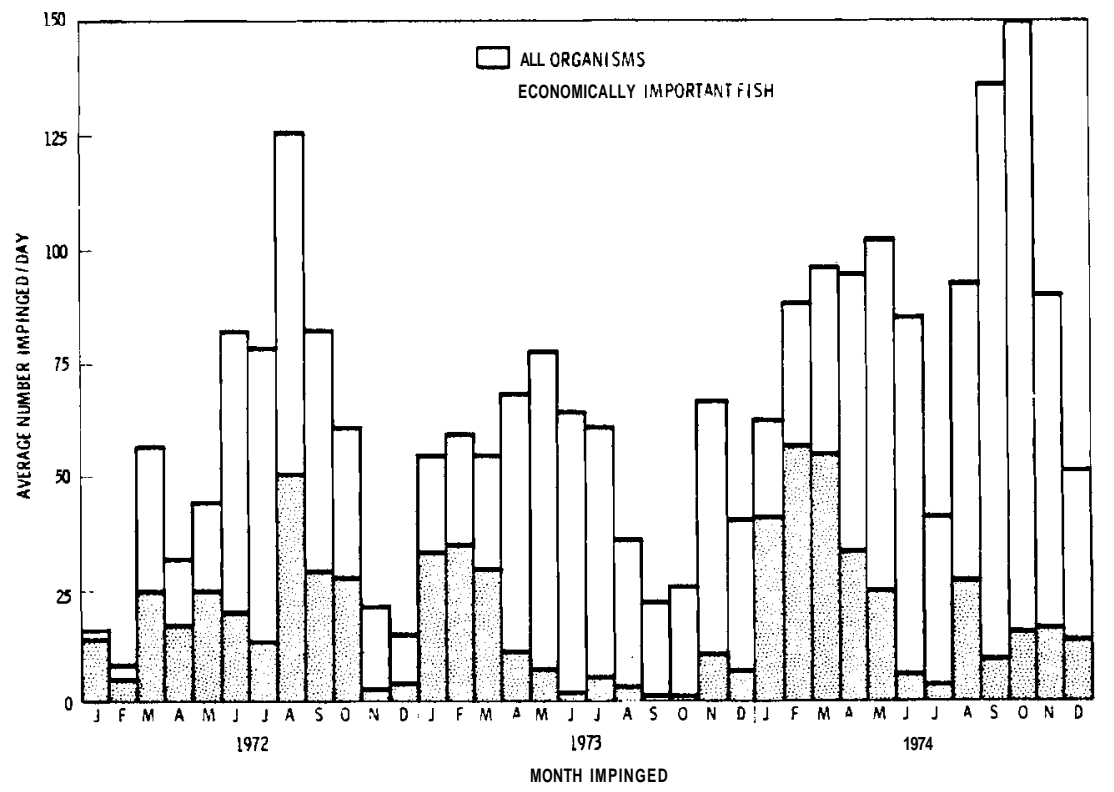

FIGURE 25. Monthly Estimates of Average Economically Important Fish and Total Organisms Impinged/ Day at the Millstone Nuclear Power Station 
TABLE 23. Numbers of the Most Numerous Species Impinged by Size Categories for Millstone Unit 1, in 1972 (275 Days Monitored)

\begin{tabular}{|c|c|c|c|c|}
\hline \multirow[t]{2}{*}{ SPECIES } & \multicolumn{4}{|c|}{ SIZE RANGE } \\
\hline & $0-7.6 \mathrm{~cm}$ & $7.6-15: 2 \mathrm{~cm}$ & $15.2 \mathrm{~cm}$ AND OVER & SPECIES TOTAL \\
\hline ATLANTIC MENHADEN & 0 & 0 & 424 & 424 \\
\hline BLUEBACK HERRING & 1636 & 68 & 3 & 1707 \\
\hline WINTER FLOUNDER & 122 & 742 & 1046 & 1910 \\
\hline WINDOWPANE ROUNDER & 3 & 109 & 1443 & 1555 \\
\hline AILANTIC SILVERSIDE & $3 \%$ & 191 & 0 & 541 \\
\hline GRUBBY & $\pi$ & 129 & 4 & 210 \\
\hline THREESPINE STICKLEBACK & 217 & 8 & 0 & 225 \\
\hline BLUE CRAB & 112 & 1762 & 148 & 2022 \\
\hline AMERICANLOBSTER & 9 & 619 & 348 & 976 \\
\hline ROCK CRAB & 4 & 4 & 0 & 8 \\
\hline GREEN CRAB & 208 & 30 & 0 & 28 \\
\hline LADY CRAB & 1842 & 78 & 0 & 1920 \\
\hline JONAH CRAB & 364 & 109 & 65 & 538 \\
\hline SPIDER CRAB & 762 & 11 & 0 & 21 \\
\hline HERMIT CRAB & 1 & $\boldsymbol{x}$ & 0 & 21 \\
\hline HORSESHOE CRAB & 1 & 0 & 19 & $\mathbf{2 0}$ \\
\hline SQUID & 0 & 0 & 0 & 0 \\
\hline TOTAL SIZE CATEGORIES & 5708 & 3880 & 3500 & 13088 \\
\hline PERCENTAGE O $A$ ALL & 95.5 & 77.2 & 75.5 & 8.7 \\
\hline PERCENTAGEECONOMIC FISH & H 29.8 & 183 & 629 & 35.8 \\
\hline PERCENTAGE OTHER FISH & 10.9 & 6.5 & 0.1 & 6.2 \\
\hline PERCENTAGE SHELLFISH & 55.9 & 524 & 125 & 41.7 \\
\hline
\end{tabular}

TABLE 24. Numbers of the Most Numerous Species Impinged by Size Categories for Mil 1stone Unit 1, in 1973 (361 Days Monitored)

\begin{tabular}{|c|c|c|c|c|}
\hline \multirow[t]{2}{*}{ SPECIES } & \multicolumn{4}{|c|}{ SIZE RANGE } \\
\hline & $0-7.6 \mathrm{~cm}$ & $7.6-15.2 \mathrm{~cm}$ & $15.2 \mathrm{~cm}$ AND OVER & SPECIES TOTAL \\
\hline ATLANTIC MENHADEN & 1113 & 276 & 58 & 144 \\
\hline BLUEBACK HERRING & 38 & 120 & 100 & 258 \\
\hline WINTER FLOUNDER & 2382 & 2179 & 1594 & 6155 \\
\hline WINDOWPANE FLOUNDER & 26 & 175 & 514 & 715 \\
\hline ATLANTIC SILMRSIDE & 303 & 640 & 126 & 1069 \\
\hline GRUBBY & 835 & 429 & 7 & 1271 \\
\hline THREESPINE STICKLEBACK & 1309 & 0 & 0 & 1309 \\
\hline BLUE CRAB & 301 & 522 & 63 & 88 \\
\hline AMERICAN LOBSTER & 1182 & 53 & 1 & 1236 \\
\hline ROCK CRAB & 966 & 58 & 0 & 1024 \\
\hline GREEN CRAB & 737 & 5 & 0 & 742 \\
\hline LADY CRAB & 2739 & 56 & 0 & 2795 \\
\hline JONAH CRAB & 0 & 0 & 0 & 0 \\
\hline SPIDER CRAB & 85 & 31 & 13 & 129 \\
\hline HERMIT CRAB & 11 & 0 & 0 & 11 \\
\hline HORSESHOE CRAB & 4 & 0 & 16 & 20 \\
\hline SQUID & 2000 & 3130 & 1499 & 6629 \\
\hline TOTAL SIZE CATEGORIES & 14.031 & 7674 & 3991 & $26 \%$ \\
\hline PERCENTAGE OF ALI & 843 & 85.5 & 6.1 & $\infty .4$ \\
\hline PERCENTAGEECONOMIC FISH & $2 \mathrm{~L} 4$ & 30.6 & 35.8 & 26.8 \\
\hline PERCENTAGE OTHER FISH & 147 & $1 \mathrm{~L} 9$ & 21 & 11.4 \\
\hline PERCENTAGE SHEL & 37.3 & $R 1$ & 1.5 & 21.4 \\
\hline
\end{tabular}


TABLE 25. Numbers of the Most Numerous Species Impinged by Size Categories for Millstone Unit 1, in 1974 (361 Days Monitored)

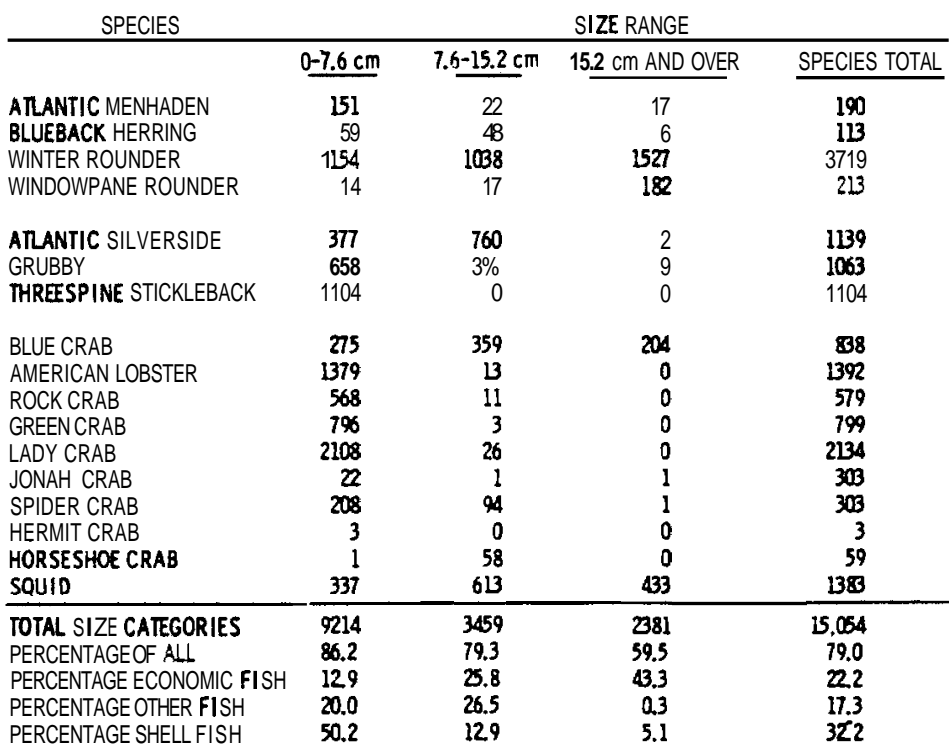

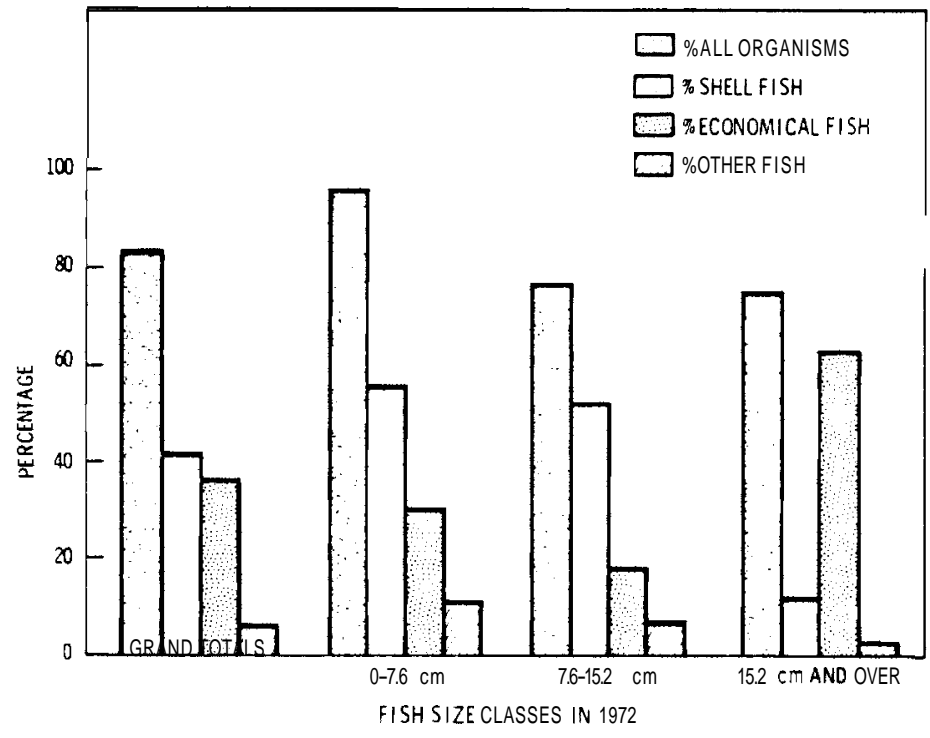

FIGURE 26. Percentage Distribution of Impingement by Size Categories for the Most Numerous Species Impinged at Millstone Nuclear Power Station in 1972 


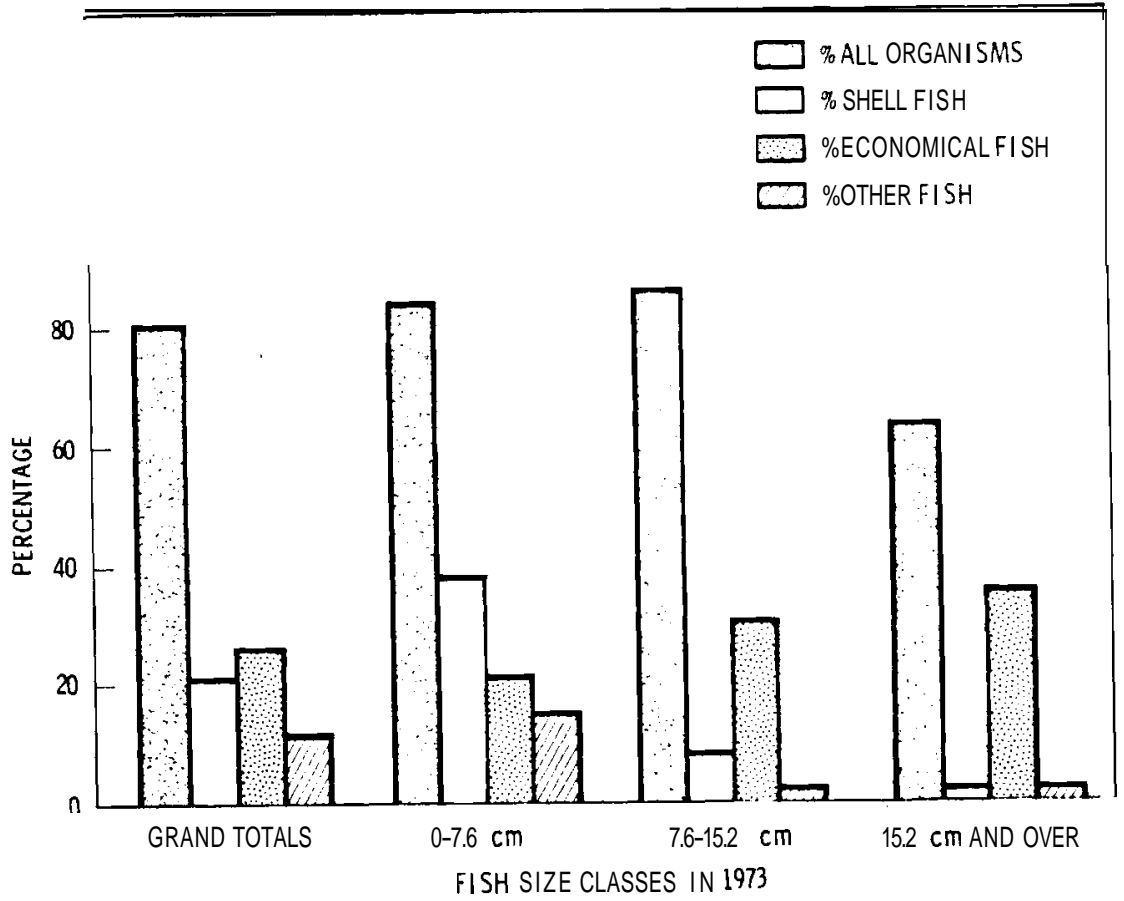

FGURE 27. Percentage Distribution of Impingement by Size Categories for the Most Numerous Species Impinged at Mil lstone Nuclear Power Station in 1973

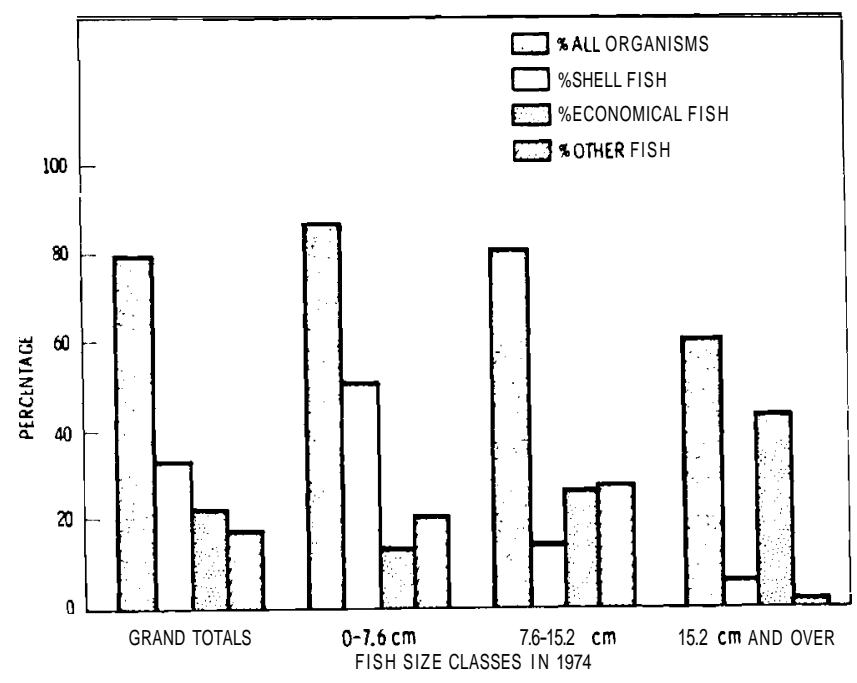

FGURE 28. Percentage Distribution of Impingement by Size Categories for the Most Numerous Species Impinged at Millstone Nuclear Power Station in 1974 
unknown relative to fish populations around Millstone, but seems trivial. Whether or not the extraordinary impingement of menhaden in 1971 was trivial will probably remain an open question.

\section{EXPOSURE PANEL}

In a draft report, Brown and Moore (1976) provided several statistical analyses of most of the species presence/absence data obtained from 19681975. In the same document the authors question the usefulness of percent organism coverage estimates as a possible indicator of change due to Millstone operations. Their rejection of these data for quantitative analyses was based on three factors: 1) the percent coverage estimates were subjective and were supposedly accurate to $\pm 5 \%$ (no explanation is given as to how this value was obtained or for its meaning), 2) the majority of the percent coverage estimates were $5 \%$ or less per panel per organism, and 3 ) the coverage estimates on each panel after 12 months were dependent on the time of settlement of initial organisms. We have not attempted a statistical analysis for the same reasons and believe the data are only useful in a qualitative manner for narrative descriptions of temporal changes at the sampling stations. It would be extremely difficult to relate any qualitative changes to Millstone operations because the station sites were ecologically different and only one control site (Giants Neck) was sampled. In addition, only one year of preoperational data was available for this station. Battelle (1975) used a chi-square analysis to determine whether categorized percent coverage was dependent on site, year, or month of occurence. Results were presented descriptively for the site analysis only and no chi-square values were given. The meaning of the chi-square analysis above with regard to the question of changes(s) attributable to Mil 1 stone operations is not clear to us. Another caveat, in addition to those above, could be added relative to assumptions implicit in the use of Chi-square. We restate our agreement with Brown and Moore that this data should not be used in an attempt to quantitatively assess change.

Species presence/absence data were evaluated by Brown and Moore (1976) using three different statistical tests (four if time series analysis was 
included). All three analysis gave the same result, i.e., no statistical differences in numbers of species counted per month per panel could be associated with Millstone operations. Since station differences of 3.5 species per month were detectable, these authors infer that any effects due to Millstone operations must be smaller than this value. On the other hand, Battelle (1975) reports that significant positive regressions of total number of different species observed per year versus year observed were obtained ( $P<0.01$, for data from 1968 to 1975) for Fox Island North, Giants Neck, and White Point. We could not ascertain whether these increases were due to increased occurence of infrequent organisms, a reflection of better and more accurate identifications during the course of the study or a reflection of increased occurence of abundant organisms. Since the change occurred at the control station also, it would be incorrect to attribute the change to the operation of Millstone.

Species diversity indices were computed using the same presence/absence values. The use of diversity and/or similarity indices to ascertain change in this study and in other studies at Millstone as well, led us to prepare a supplemental study on the usefulness of similarity measures as quantitative tools to detect changes in species composition. The results of that study, Johnston (1977a, 1977b), indicate that similarity indices are not useful for assessing changes in species composition.

\section{$\underline{\text { Summary }}$}

Only the presence/absence data were useful in a quantitative assessment of changes in numbers of boring and fouling species. Regression analyses of species presence/absence data showed no differences attributable to Millstone operations.

WNIER FLOUNDER MODEL

An extensive effort has been made to devise a model to predict the effects of larval entrainment at Millstone on winter flounder population. Three submodels were used (coupled) to accomplish this goal. The hydrodynamic section simulates local tidal circulation, the concentration 
submodel mimics dispersal of larvae, and the population submodel for flounder is of the "box and arrow" type and incorporates a Ricker type stock-recruitment curve.

Our evaluation of the biological portions of the model indicates that the assumptions made are logical and that "if" the model represents the real world, we believe the results (projections) may be conservative. This latter belief is based on the fact that no density dependent mortality features for most life stages are included in the model and because alternate areas are available to spawning females and are undoubtedly used. These factors would be expected to reduce the impact on the winter flounder populations.

When the calculated entrainment val ue $(1 \%)$ for winter flounder larvae (see section following) is used in conjunction with the model output, predicted impacts (slightly over 5\% of the local adult population would be lost over $35 \mathrm{yr}$ ) are an order of magnitude below levels which would be considered ecologically detrimental. Since the assumptions used in the model appeared conservative and since the larvae entrainment estimate is thought to be conservative, it does not appear that the flounder population is in jeprody due to the operation of Millstone 1. However, it is nearly impossible (beyond the state-of-the-art) to construct a model for most ecological populations in which we can have complete confidence. The reasons, at least for longer lived species, are usually lack of data and more iniportantly a lack of understanding as to how the species functions during all life stages. Thus, models, including this one, should- not be considered quantitative and as such we prefer to call the output from such exercises projections. In addition, in the case of the flounder model projections, we cannot separate Millstone effects from other life span insults such as oil pollution, changed fishing pressures, and carrying capacities. Another factor confounding the results is the inability to identify subpopulations.

In spite of the above caveats on the models limitations, we believe its projections can be useful in the decision process. Apparently flounder larvae entrainment was thought to be a serious problem, so appropriate field studies were required and a simulation model devised. The results and understandings now available can be used to aid in designing additional field 
sampling programs to obtain needed information identified in building and running the model (i.e. life stages, behavior, etc.). Additional changes in model structure can be made until the results are "satisfactory". Since mimicing real data is not necessarily proof of model validity, some sort of stopping rule should be agreed to so field studies are not continued indefinitely. In our discussion above, we found that projected population effects appeared to be an order of magnitude below those which are considered ecologically detrimental. Perhaps after $x$-years of model refinement and field studies, an impact estimate that is an order of magnitude below an assumed ecologically detrimental level could be a point where studies should be terminated.

$\underline{\text { Summary }}$

Whe discussed the projections obtained from use of the winter flounder model in light of both its limitations and those of such models in general. conclude that the projected effect of larval entrainment on adult flounder populations was likely conservative, but that there is no way to assess the reliability of such a statement. We proposed that the model can be used to aid the field sampling design. In addition, we have proposed a rule whereby field sampling might be ended after an appropriate number of seasons.

\section{EINTRAIMENT}

Studies were conducted on entrainment of zooplankton, phytoplankton, and ichthyoplankton from 1971-1975 by personnel of the Wood's Hole Oceanographic Institution. In addition, an off-shore sampling program for zooplankton and icthyoplankton has been conducted by Northeast Uti 7ities (1975) since 1973. In 1975 a third consultant was appointed to carry out entrainment monitoring at Millstone for both Units 1 and 2. In order to be sure data collected in this latter program would be comparable to prior studies, an extensive program of parallel testing of methods and critical review of prior data was initiated, Northeast Utilities (1975). Problems were identified and discussed and best estimates of temporal numbers and/or weight per $\mathrm{m}^{3}$ 
were usually made for the intake, discharge or Quarry Cut (but principally the discharge). Estimates of daily entrainment were made by multiplying the maximum $24 \mathrm{hr}$ flow through the reactor by the abundance $/ \mathrm{m}^{3}$ and using this value to represent daily totals between different sampling days (usually not less than 4 or more than 17). In this way monthly and yearly numbers entrained could be obtained by summing over appropriate intervals. We have previously noted, Gore et al. (1976a), that such a procedure can sometimes introduce a large bias when daily "catch" varies widely.

In order to estimate the fraction of the available organisms entrained, an assessment of the population in a defined source area is needed. This can be accomplished for some fish species either by sampling the source area (fraught with sampling and interpretive difficulties) or by using estimates of numbers of spawning females, associated fecundities, and hatching success to obtain a yearly estimate. This latter method of calculating the population value is questionable because the estimates used in its construction are often qualitative estimates. In the latter case, variability of fraction entrained would be expressed from year to year while the use of sampling methods gives more within year estimates (an expensive proposition). In the case of Mil 1stone 1, the only estimate we found was $1.1 \%$ for winter flounder, Northeast Utilities (1975) and was based on estimated adult population parameters as outlined above. Arguments are presented that this is a conservative estimate. The meaning of such an entrainment to the flounder population is unknown. However, a population model (discussed in the previous section) indicates 1ittle effect, particularly if this entrainment estimate is actually conservative. If, in addition, the other aspects of the flounder model are conservative, then no effect would be projected due to Millstone 1 operations.

Using surface outflow from Long Island Sound, the flow through the Millstone stations, data on zooplankton numbers (cel1s $/ \mathrm{m}^{3}$ ), and a $70 \%$ mortality estimate, between 0.08 and $0.27 \%$ of the surface zooplankton population was apparently killed by Millstone operations. Use of some alternative 
assumptions about flow can result in slightly higher estimates. Some reservations about the accuracy of the zooplankton data have been expressed, Northeast Utilities (1975). The questions principally concern flow measurements taken in conjunction with zooplankton sampling. If the mortalities from the operation of other power plants located on the Sound are added to the above value then larger fractions of the Sound's surface populations are undoubtedly killed. Since zooplanktons reproduce rapidly, such entrainment levels appear easily tolerated.

\section{$\underline{\text { Summary }}$}

Initial estimates of the fraction of flounder and zooplankton entrained and killed were made. Such factors as net avoidance and extrusions were not considered. Additional estimates for different times and other fish species should be made to identify peculiarities of season and to obtain a notion of the range of values. It appears that the use of these values in "population models" may be useful in assessing possible population effects, at least on an order of magnitude basis. Once adequate estimates of the entrained fraction are obtained then these studies should be terminated. 


\section{LITERATURE CITED}

Battelle, Columbus Labs., Wm. F. Clapp Labs., Duxbury, Mass. 1975: Annual Report on A Monitoring Program on the Ecology of the Marine Environment of the Millstone Point, Connecticut Area, Vol. I. To: iNortheast Utilities Service Company. Report No. 14592.

Brown, Russel T. and S. F. Moore, 1976. An Analysis of Exposure Panel Data Collected at Millstone Point, Connecticut. Mass. Inst. of Technology, Cambridge, MA 103 pp.

Dunn, W. E., A. J. Policastro and R. A Paddock. 1975. Surface Thermal Plumes: Evaluation of Mathematical Models for the Near and Complete Field. Argonne National Laboratory, Report No. ANL/WR-75-3.

Gore, K. L., J. M. Thomas, L. D. Kannberg and D. G. Watson. 1976a. Evaluation of Monticello Nuclear Generating Plant, Environmental Impact Prediction, Based on Monitoring Programs. BNWL-2150, NRC-1.

Gore, K L., J. M. Thomas, L. D. Kannberg, J. A. Mahaffey and D. G. Watson. 1976b. Evaluation of Haddam Neck (Connecticut Yankee) Nuclear Power Plant, Environmental Impact Prediction, Based on Monitoring Programs. BNWL-2151, NRC-1.

Harleman, D. R. F., Editor. 1972. Temperature distributions in the far field region - partial mixing, In: Engineering Aspects of Heat Disposal from Power Generations. Department of Civil Engineering, Massachusetts Institute of Technology.

Johnston, J. W. 1977a. Similarity Indices I = What Do They Measure? BNWL2152, Addendum. Battelle Northwest, Richland, WA.

Johnston, J. W. 1977b. Similarity Indices II: The Power of Goodal1's Significance Test for the Simple matching Coefficient. BNWL-2152, Addendum. Battelle Northwest, Richland, WA

Leendertse, J. J. 1967. Aspects of a Computational Model for Long-period Water Wave Propagation, Rand Corporation, Santa Monica, Memorandum RM-5294-PR.

Northeast Utilities Service Company. 1975. Summary Report, Ecological and Hydrological Studies, May 1966 through December 1974, Millstone Nuclear Power Station, Docket Nos. 50-245, 50-336 and 50-423.

Sessenwine, M. P., K W. Hess and S. B. Saila. 1975. Interim Report on Evaluating the Effect of Power Plant Entrainment on Populations Near Mi11stone Point, Connecticut. A Report to Northeast Utilities Service Company from Marine Experiment Station, Graduate School of Oceanography, University of Rhode Island, MES-NUSCO Rept. No. 3. 
Stolzenback, K. D. and D. R. F. Harleman. 1971. An Analytical and Experimental Investigation of Surface Discharges of Heated dater, Report No. 135, Department of Civil Engineering, Massachusetts Institute of Technology.

U.S. Atomic Energy Commission, Directorate of Licensing. 1973. Final Environmental Statement; Related to the Continuation of Construction of Unit 2 and the Operation of Units 1 and 2, Millstone Nuclear Power Station Millstone Point Company, Docket Nos. 50-245 and 50-336.

U.S. Nuclear Reaulatory Commission. 1975. Appendix B to Operating License No. DPR-21, Environmental Technical Specifications for Millstone Nuclear Power Station Unit 1, Docket No. 50-245. 


\section{DISTRIBUTION}

No. of

$\underline{\text { Copies }}$

OFFSITE

A. A. Churm

ERDA Chicago Patent Group 9800 south- ass Avenue. Argonne, IL 60439

3 M. Jinks, Chief Mail and Files

USNRC Central Files

Washington, DC 20555

245 ERDA Technical Information Center

For Basic Distribution Under NRC-1

P. G. Voilleque

ADA Health Services Laboratory Idaho Falls. ID 83401

H. T. Peterson

USNRC Office of Standards Development

Wash ington, DC 20555
No. of

$\underline{\text { Copies }}$

ONSITE

GDA Richland Operations Office

P. G. Holsted

Atlantic Richfield Hanford Company

G. E. Backman

United Nuclear Industries, Inc.

A. E. Engler

Hanford Engineering Development Laboratory

G. D. Carpenter

60 Battelle-Northwest

K. L. Gore (10)

J. L. Helbling (2)

C. Hudgens

J. Johnston

L. D. Kannberg (10)

J. Mahffey (5)

J. M. Thomas (10)

D. G. Watson (10)

B. E. Vaughan (2)

Technical Information Files (5)

Technical Publications (3) 